\title{
IAWA LIST OF MICROSCOPIC BARK FEATURES
}

\author{
IAWA Committee: \\ Veronica Angyalossy - São Paulo, Brazil \\ Marcelo R. Pace - São Paulo, Brazil/Washington D.C., U.S.A. \\ Ray F. Evert - Madison, U.S.A. \\ Carmen R. Marcati - Botucatu, Brazil \\ Alexei A. Oskolski - Johannesburg, South Africa \\ Teresa Terrazas - Mexico City, Mexico \\ Ekaterina Kotina - Johannesburg, South Africa \\ Frederic Lens - Leiden, The Netherlands \\ Solange C. Mazzoni-Viveiros - São Paulo, Brazil \\ Guillermo Angeles - Xalapa, Mexico \\ Silvia R. Machado - Botucatu, Brazil \\ Alan Crivellaro - Padua, Italy \\ Karumanchi S. Rao - Gujarat, India \\ Leo Junikka - Helsinki, Finland \\ Nadezhda Nikolaeva - Petrozavodsk, Russia \\ Pieter Baas - Leiden, The Netherlands
}

To be cited as: Angyalossy V, Pace MR, Evert RF, Marcati CR, Oskolski AA, Terrazas T, Kotina E, Lens F, Mazzoni-Viveiros SC, Angeles G, Machado SR, Crivellaro A, Rao KS, Junikka L, Nikolaeva N, \& Baas P. 2016. IAWA List of Microscopic Bark Features. IAWA Journal 37 (4): 517-615.

\section{Edited by}

Veronica Angyalossy, Marcelo R. Pace \& Pieter Baas

(C) 2016. IAWA Journal 37 (4): 517-615

International Association of Wood Anatomists c/o Naturalis Biodiversity Center, Leiden, The Netherlands

DOI 10.1163/22941932-20160151 


\section{Contents}

Preface ............................. 519

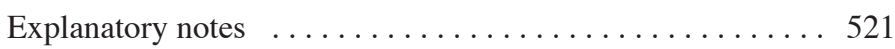

List of Features . . . . . . . . . . . . . . . . . . . . 524

Bark and Sieve elements $\ldots \ldots \ldots \ldots \ldots \ldots \ldots \ldots \ldots \ldots$

Dilatation phenomena ..................... 544

Axial parenchyma ....................... 546

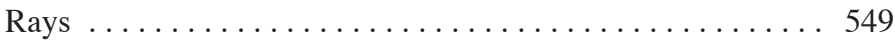

Sclerenchyma: Fibers and Sclereids . . . . . . . . . . 560

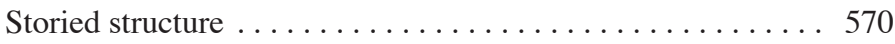

Phloem growth rings $\ldots \ldots \ldots \ldots \ldots \ldots \ldots \ldots \ldots$

Primary phloem . ................... 570

Cortex ... . . . . . . . . . . . . . . . . . . . . . . 572

Variation in the location of the phloem .......... 573

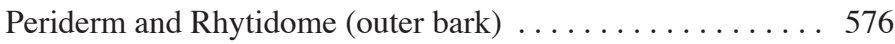

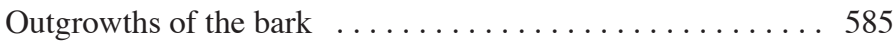

Mineral and organic inclusions .............. 587

Secretory structures . . . . . . . . . . . . . . . . . . 595

Non-anatomical information $\ldots \ldots \ldots \ldots \ldots \ldots \ldots 60 . \ldots \ldots$

References ............................... 602

Appendix - Methods .................. 609

Supplementary material of this IAWA List of Microscopic Bark Features, titled "Recipes and protocols for histochemical tests", by Solange C. Mazzoni-Viveiros and Marília de Moraes Castro, can be accessed in the online edition of this journal via:

http://booksandjournals.brillonline.com/content/journals/ 


\section{PREFACE}

Bark, here defined as all tissues outside the vascular cambium of trees, shrubs, or lianas, fulfills vital functions in the living plant, such as the transport and (re)distribution of photosynthates and signaling molecules to different plant parts, mechanical support, and protection against solar radiation, drought, physical damage, plant pathogens and herbivores. Its dynamic microscopic and macroscopic diversity (barks continue to change as trees age) offers a wealth of diagnostic features to help recognize species or genera and sometimes even plant families and orders. The different character states of bark cells and tissues retain strong phylogenetic signals, making bark a rich source of information for plant systematics. In addition, bark yields a wealth of raw materials for fiber products, cork, medicinal compounds, spices, rubber, dyes and high energy biomass. Some of these uses are traditional and of special interest in ethnobotany, others are of continued or even increasing importance in the global economy.

Despite the fact that barks have been studied from the early days of microscopy, and that carbohydrate and plant hormone transport in the phloem remain important research topics, the knowledge of comparative bark microscopy and macroscopy strongly lags behind that of wood (secondary xylem). To help remedy this situation, an IAWA Committee was established by the International Association of Wood Anatomists, to develop an annotated and illustrated list of terms of bark features in angiosperms and gymnosperms, recommended in comparative bark studies and in species recognition.

The resulting IAWA List of Microscopic Bark Features presented here stands in a long tradition. From its foundation in 1931 the International Association of Wood Anatomists has taken the lead in setting international standards in wood anatomical terms and character state definitions (IAWA Committee 1933, 1964, 1989, 2004). The IAWA Hardwood and Softwood Lists (IAWA Committee 1989, 2004) are now internationally accepted, adopted by widely used web-based identification tools such as InsideWood (2004-onwards; Wheeler 2011), and in all modern literature on comparative wood anatomy.

For bark structure the IAWA Journal published two comprehensive proposals for bark terminological standards, one by Trockenbrodt (1990 - microscopy), and the other by Junikka (1994 - macroscopy). These publications constituted important starting points for the work of our Committee. Other important precursors that were consulted are by Roth (1981), Van Wyk (1991, unpublished), Lev-Yadun (1991), Richter et al. (1996), and Yeremin \& Kopanina (2012). Esau's Plant Anatomy (Evert 2006) also provided a very important source and we gratefully borrowed from its glossary for many of the definitions adopted here. Among the older literature cited the Encyclopedia of Plant Anatomy volume by Esau (1969) on The Phloem deserves special mention, and is strongly recommended for further reading.

One of the reasons why bark structure has remained relatively poorly studied, is that it is composed of both very soft and hard, and both permeable and impermeable 
tissues. This creates special problems for preservation and sectioning. We have therefore included an appendix on methods with some references to user-friendly protocols and recipes with this list. In the supplementary material of this List*) there are detailed protocols developed by Solange C. Mazzoni-Viveiros and Marília de Moraes Castro for microchemical testing of certain compounds to be found in barks.

The establishment of the IAWA Bark Committee was a Brazilian initiative. Following enthusiastic approval by the international IAWA Council, a first planning meeting was held in the framework of the IAWA Symposium in Recife (Pernambuco, Brazil) in October 2012. During an intensive workshop in Brotas (São Paulo, Brazil) from 18-24 May 2014, the outline of the list and character definitions were discussed and agreed. From 10-14 January 2016 four of us (Veronica Angyalossy, Pieter Baas, Ray F. Evert, and Marcelo R. Pace) met in Madison, Wisconsin, U.S.A. to select illustrations and engage in a subfinal round of text editing. We wish to acknowledge generous financial support from the São Paulo Research Foundation (FAPESP; process 2013/27044-8; 2013/10679-0) and the University of São Paulo (Brazil).

We hope that this list will stimulate research of bark that is of such great importance in tree biology and constitutes a source of valuable natural products. We also hope that it will be used for the establishment of databases to assist microscopic identification of the barks of trees, lianas, and shrubs.

\section{The IAWA Committee:}

Veronica Angyalossy, São Paulo, Brazil

Marcelo R. Pace, São Paulo, Brazil/Washington D.C., U.S.A.

RAY F. Evert, Madison, U.S.A.

CARMEn R. MARCATI, Botucatu, Brazil

AleXei A. OsKolski, Johannesburg, South Africa

Teresa Terrazas, Mexico City, Mexico

EKATERINA Kotina, Johannesburg, South Africa

Frederic Lens, Leiden, The Netherlands

Solange C. Mazzoni-Viveiros, São Paulo, Brazil

Guillermo Angeles, Xalapa, Mexico

Silvia R. Machado, Botucatu, Brazil

Alan Crivellaro, Padua, Italy

KARUMANCHI S. RAO, Gujarat, India

LeO JunikKa, Helsinki, Finland

NAdEZHDA NikolaEva, Petrozavodsk, Russia

PIETER BAAs, Leiden, The Netherlands

*) See the online edition of this IAWA Journal issue. 


\title{
EXPLANATORY NOTES
}

\begin{abstract}
Aims
The IAWA List of Microscopic Bark Features has a dual aim to 1) provide an illustrated and annotated glossary of terms used in bark anatomy of both angiosperms and gymnosperms, and 2) code and define bark anatomical character states that could be used for constructing databases for microscopic bark identification or comparative analyses of functional and/or phylogenetically informative bark traits.
\end{abstract}

\section{Sequence of features}

This List deals with bark features in the following sequence: conducting elements and their associated cells (separately for angiosperms and gymnosperms; most other features apply to both angiosperms and gymnosperms), dilatation phenomena (in general), axial parenchyma, rays, sclerenchyma (at the cellular and tissue level), storied structure, growth rings, variations in location of the phloem, rhytidome (outer bark) and periderm (including lenticels and outgrowths), mineral and organic inclusions, secretory structures, and non-anatomical information.

\section{Definitions, comments and examples}

Features or character states are first concisely defined, unless the descriptor is fully self-explanatory. In comment sections additional information is provided, usually on occurrence, sometimes on development or problems in recognition of the feature or character state. The examples cited are a selection from the literature or from research or teaching experience among the IAWA Committee members. Because most plant families have not been studied in detail from a bark anatomical point of view or without sufficient species coverage, the examples listed can only be eclectic and are not fully representative.

\section{Numerical codes}

The hybrid nature of the IAWA Bark List as an illustrated glossary and an inventory of diagnostic character states has complicated the attribution of numerical codes. Roughly speaking, the following categories can be distinguished:

- No code given: This list defines and illustrates numerous features that can be encountered in all barks, such as for instance presence of sieve elements, sieve areas, conducting and nonconducting phloem, P-protein, and callose. Because of their ubiquitous presence these general features have not been given numerical codes.

- Code coincides with feature: In many cases features that only have presence or absence as divergent character states have been given a single code. Examples are nacreous walls (13), septate fibers (68), gelatinous fibers (69), sclereids (71), fiber-sclereids (72), all crystal types and silica bodies (129-144) and most secretory structures (158-173). Coding for these features automatically implies presence, and noncoding would indicate absence. 
- Different character states of one overarching feature are coded separately. This applies to most features such as sieve-tube grouping and distribution (1-4), sieve plates (5-10), companion cells (16-21), dilatation in the rays (25-27), parenchyma distribution (31-35), parenchyma strand length (36-39), ray width and height (45-51), ray composition (52-55), and sclerification of rays (59-62).

- Double coding of general features and more specific character states: In several instances we have given codes both to presence of a general feature (e.g. fibers (64), secretory cells (158), laticifers (163), and canals lined with an epithelium (168)) as well as to the various types or qualifiers for various fiber types and shapes (65-69), secretory cells (oil, mucilage, tannin, myrosin cells, 159-162), nonarticulated and articulated laticifers $(164,165)$, and resin or gum ducts lined with an epithelium (169, 170). This was done because, even in the absence of further detailed information, the simple presence or absence of fibers, secretory cells, laticifers and epithelia is important and informative.

- Quantitative features: For a selected number of features such as sieve-element size and fiber length character codes are listed. Recommended parameters to be recorded are: mean values \pm standard deviation, full range, and the number of measurements $(n=x)$.

When the IAWA Committees (1989 and 2004) compiled the Hardwood and Softwood Lists, a great attempt was made to keep the number of coded features to a minimum. For instance, the Hardwood List does not code for the default condition of vessel grouping in hardwoods (solitary and in short radial multiples) because that condition follows automatically for coding absence of "exclusively solitary vessels" or "vessel multiples of over four common". This extremely parsimonious attitude towards coding was partly inspired by the presumed limitations on computing capacity and speed, which have completely been overtaken by developments in computing and informatics. We are aware that in the current list there may be some coding redundancy (see for instance "double coding" - above), but we have chosen to allow that.

\section{Illustrations}

Great care was taken to select representative micrographs to illustrate most bark features defined in this list. All Committee members provided illustrations, but many if not most of the micrographs in this list were specially prepared from the rich personal slide collection of Ray Evert, which encompasses slides from his own work and that of Vernon Cheadle and Cornell University slides. This rich collection, currently with Carmen Marcati (UNESP, Botucatu) and Veronica Angyalossy (USP, São Paulo), was fundamental to compose the present list. For a number of features new sections were specially prepared at USP, São Paulo. Veronica Angyalossy, Carmen Marcati and Marcelo Pace screened the entire collection to photograph and search for the best photos, which were then reviewed and selected in Madison-WI by Ray Evert, Pieter Baas, Veronica Angyalossy and Marcelo Pace. Marcelo Pace finally edited and composed all the plates. 


\section{Microtechnique and staining protocols}

Because bark with its mixture of soft and hard tissues poses problems in sectioning, a methodology section is given as appendix to this list (page 609), with recommendations for fixation, embedding, sectioning, and staining. For specific staining and microchemical tests of organic inclusions protocols drafted by Solange C. Mazzoni-Viveiros and Marília de Moraes Castro are provided electronically as supplementary material with this IAWA Journal issue (see the online edition of this IAWA Journal).

\section{Limitations}

Initially, we planned to integrate bark microscopy with bark macroscopy in a combined list, because the huge and often diagnostic diversity of the outer bark can best be understood in combination with the underlying microscopic processes of dilatation, development of sequent phellogens, and the origin of patterned cracks or abscission layers (Junikka 1994; Evert 2006). Moreover, the practical links between microscopy and macroscopy are equally important in bark as in wood identification (Ruffinatto et al. 2015). Unfortunately we did not succeed in finalizing the macroscopic section of the bark list in time, but we hope to remedy this in the future.

Although we consulted and cited hundreds of original papers and reference books on bark anatomy, the list of references should not be seen as a complete bibliography on bark microscopy. Users are advised to consult more comprehensive bibliographies in for instance Esau (1969) and Evert (2006).

The IAWA List of Microscopic Bark Features provides a fairly comprehensive and ordered overview of bark anatomical diversity. Nevertheless, we are aware that there is more variation in structural detail in barks of angiosperms and gymnosperms than we have described or coded here. This List should therefore primarily be seen as a practical framework for studies of comparative bark anatomy, and we hope it will inspire much future research on the microscopy, development, and physiology of this crucial part of the plant body. 


\section{LIST OF FEATURES}

\section{CODED ANATOMICAL FEATURES *)}

\section{Secondary phloem}

Angiosperms

\section{Sieve-tube elements and companion cells}

\section{Sieve-tube grouping and distribution}
1. Solitary and in small groups
2. In radial rows
3. In tangential bands
4. In clusters

\section{Sieve plate complement}

5. All sieve plates simple

6. Simple and scalariform or reticulate (compound) sieve plates present

7. All sieve plates scalariform

8. Scalariform plates with $<10$ sieve areas

9. Scalariform with $\geq 10$ sieve areas

10. Reticulate sieve plates present

\section{Sieve plate inclination}

11. Transverse and/or slightly inclined

12. Strongly inclined

\section{Other sieve-tube features}

13. Nacreous walls

14. Sieve-tube size (area and/or diameter)

15. Sieve-tube element length

\section{Companion cells}

16. One companion cell per sieve-tube element

17. Two companion cells on opposite sides of the sieve tube

18. Two or more companion cells lying along the sieve tube

19. Companion cells fusiform

20. Companion cells in strands of 2 cells

21. Companion cells in strands of $>2$ cells

*) In addition to coded features this List includes definitions and illustrations of many other bark features that are common to all or most barks and have therefore not been given a numerical code. 


\section{Gymnosperms}

\section{Sieve cells}

22. Sieve cell size (area and/or diameter)

23. Sieve cell length

\section{Strasburger cells}

24. Strasburger cells present

\section{Angiosperms and Gymnosperms}

\section{Dilatation phenomena}

25 . In the rays

26. By cell expansion only

27. By anticlinal cell division and cell expansion

28. In axial parenchyma

29. In both axial parenchyma and rays

30. In the cortex and/or epidermis

\section{Axial parenchyma}

\section{Parenchyma distribution}

31. Diffuse and diffuse-in-aggregates

32. Narrow bands

33. Broad bands

34. Sieve-tube-centric

35. Axial parenchyma constitutes the ground tissue

\section{Parenchyma strand length}

36. Fusiform or two cells per parenchyma strand

37. 3-4 cells per parenchyma strand

38. 5-8 cells per parenchyma strand

39. Over eight cells per parenchyma strand

\section{Rays}

\section{Course of rays}

40. Straight

41. Undulated or wavy

\section{Ray dilatation}

42. (Seemingly) absent

43. Slightly dilated

44. Strongly dilated (wedge-shaped) 


\section{Ray width and height}

45. Rays exclusively uniseriate

46. Rays 1 to 3 cells wide

47. Larger rays commonly 4 - to 10 -seriate

48. Larger rays commonly $>10$-seriate

49. Rays of two distinct sizes

50. Ray height (in $\mathrm{mm}$ )

51. Rays of over $1 \mathrm{~mm}$ tall

\section{Ray composition}

52. All ray cells procumbent

53. All ray cells upright

54. Body ray cells procumbent with one to many rows of upright and/or square marginal cells

55. Rays with procumbent, square and upright cells mixed throughout the rays

56. Sheath cells present

57. Ray sieve-tube elements present

\section{Ray aggregation}

58. Aggregate rays present

\section{Sclerification of rays}

59. Absent

60. Ray cells sclerified only when touching axial sclerenchyma cells

61. Central or scattered groups of ray cells sclerified

62. (Almost) all ray cells sclerified

\section{Rays absent}

63. Phloem rayless

\section{Sclerenchyma: fibers and sclereids}

\section{Fibers, fiber-sclereids, and sclereids (cellular level)}

64. Fibers present

65. Fiber shape rounded to polygonal

66. Fiber shape square

67. Fiber shape tangentially elongate

68. Septate fibers (and/or fiber-sclereids) present

69. Gelatinous fibers present

70. Fiber length

71. Sclereids present

72. Fiber-sclereids present 


\section{Sclerification at the tissue level}

73. Absent

74. Present

75. Fibers only

76. Sclereids only

77. Fibers and sclereids (including fiber-sclereids) mixed together

\section{Arrangement of fibers, fiber-sclereids and sclereids}

78. Diffuse and diffuse-in-aggregates

79. Clusters

80. Tangential bands

81. Fibers constituting the ground tissue of the secondary phloem

82. Radial rows

\section{Fiber or fiber-sclereid band width}

83. Narrow: 1-2 cells wide

84. Medium: (2-)3-5 cells wide

85. Wide: more than 5 cells wide

\section{Storied structure}

86. Phloem elements nonstoried

87. All rays, axial parenchyma and sieve-tube elements storied

88. Low rays storied, high rays nonstoried

89. Axial parenchyma and/or sieve elements storied

90. Rays and/or axial elements irregularly storied

\section{Pericyclic and protophloem fibers and sclereids}

91. Pericycle remaining parenchymatous

92. Pericycle with a ring of discrete fiber strands embedded in parenchyma

93. Pericycle with a continuous or nearly continuous closed ring of fibers

94. Pericycle with alternating groups of fibers and sclereids in a continuous or nearly continuous ring

\section{Variation in the location of the phloem}

95. Intraxylary phloem present

96. Phloem strands or bands produced by successive cambia present throughout the stem

97. Interxylary phloem produced by a single cambium present throughout the stem

98. Phloem wedges present 


\section{Periderm and Rhytidome (outer bark)}

\section{Origins of the first periderm}

99. Epidermal

100. Subepidermal layer

101. Second and third cortical layers

102. Deep-seated: in inner cortex, endodermis, pericycle or the phloem

\section{Arrangement of sequent periderms in TS}

103. Reticulate

104. Concentric

\section{Types of phellem cells}

105. Phellem cells evenly thin-walled

106. Phellem cells evenly thick-walled and sclerified

107. Phellem cells with U-shaped wall thickenings

108. Phellem cells with inversely U-shaped wall thickenings

109. Phelloid cells present

\section{Stratification and aerenchyma in the phellem}

110. Alternating bands of thin-walled and thick-walled phellem cells

111. Alternating layers of cells with and without dark contents

112. Phellem nonstratified

113. Phellem aerenchymatous

\section{Phelloderm thickness}

114. Thin (1-3 cell layers)

115. Thick (more than 3 cell layers)

\section{Cell types and phelloderm stratification}

116. Phelloderm cells parenchymatous

117. Phelloderm cell walls evenly thickened and sclerified

118. Phelloderm cells sclerified with U-shaped or inversely U-shaped wall thickenings

119. Phelloderm consisting of alternating sclerified or nonsclerified cell layers

120. Phelloderm and phellem cells square and/or rectangular (tangentially elongate)

121. Phelloderm and phellem cells radially elongate

\section{Lenticels}

122. Filling tisssue nonstratified (homogeneous) and suberized

123. Filling tissue nonstratified (homogeneous) and largely nonsuberized

124. Filling tissue stratified (heterogeneous) 


\section{Outgrowths of the bark}

125. Prickles present

126. Prickles originating from the cortex

127. Prickles originating from the phellogen

128. Winged bark present

\section{Mineral and organic inclusions}

\section{Mineral inclusions}

\section{Crystal shape}

129. Prismatic crystals

130. Druses

131. Raphides

132. Acicular crystals

133. Styloids and elongated crystals

134. Crystal sand

\section{Crystals of other shapes (mostly small)}

135. Cubical crystals

136. Navicular crystals

137. Spindle-shaped crystals

138. Pyramidal crystals

139. Diamond-shaped crystals

140. Tabular crystals

141. Indented and twinned crystals

142. Acicular crystals in variously-shaped aggregates

143. Sphaerites or sphaerocrystals

\section{Silica}

144. Silica bodies

145. Vitreous silica

\section{Distribution of mineral inclusions}

146. In single axial parenchyma cells

147. In chambered axial parenchyma cells

148. In ray parenchyma cells

149. In fibers

150. In sclereids

151. In cristarque cells

152. In cell walls

153. In cortical cells

154. In phelloderm cells

155. In phellem cells 


\section{Organic inclusions}

156. Starch

157. Fructans including inulin

\section{Secretory structures}

158. Secretory cells

159. Oil cells

160. Mucilage cells

161. Tannin cells

162. Myrosin cells

163. Laticifers

164. Nonarticulated laticifers (latex cells)

165. Articulated laticifers (latex vessels)

166. Tanniniferous tubes/tubules

167. Secretory intercellular spaces (canals/ducts and cavities)

168. Secretory epithelium present

169. Resin ducts

170. Gum ducts

171. Mucilage cavities or canals

172. Breakdown ray areas

173. Kino veins

\section{Non-anatomical information}

\section{Habit}

174. Tree

175. Shrub

176. Vine/Liana

\section{Name \& geographical distribution}

177. Family, genus, species, authority

178. Geographical distribution

\section{Common legend for the staining used in the color plates}

$\mathrm{ab} / \mathrm{s}=$ Astra-blue and safranin

$\mathrm{acb} / \mathrm{s}=$ Alcian blue and safranin

$\mathrm{cv}=$ Crystal violet

$\mathrm{fg} / \mathrm{s} \quad=$ Fast-green and safranin

$\mathrm{h} / \mathrm{mg}=$ Hematoxylin $\&$ malachite green

$\mathrm{lb} / \mathrm{s}=$ Light blue and safranin

$\mathrm{n} \quad=$ Natural (unstained)

$\mathrm{og} / \mathrm{cv}=$ Orange $\mathrm{G}$ and crystal violet

$\mathrm{rb} / \mathrm{fc}=$ Resorcine blue and ferric chloride

$\mathrm{s}=$ Safranin

tb = Toluidine blue 


\section{BARK AND SIEVE ELEMENTS}

\section{Bark}

Definition: All tissues outside the vascular cambium.

Comments: In older trees, lianas and shrubs the bark may be divided into outer bark and inner bark (fig. $1 \& 2$ ). The inner bark consists of secondary phloem. The outer bark, also named rhytidome, corresponds to the innermost periderm and subsequent periderms with the tissues isolated by them. Each periderm is formed by the phellogen and its derivatives, the phellem and phelloderm. The outer layers of the rhytidome can be shed as trunks and branches mature and age. In the literature outer and inner bark are sometimes misleadingly contrasted as dead and living bark. However, the outer bark also contains living cells.
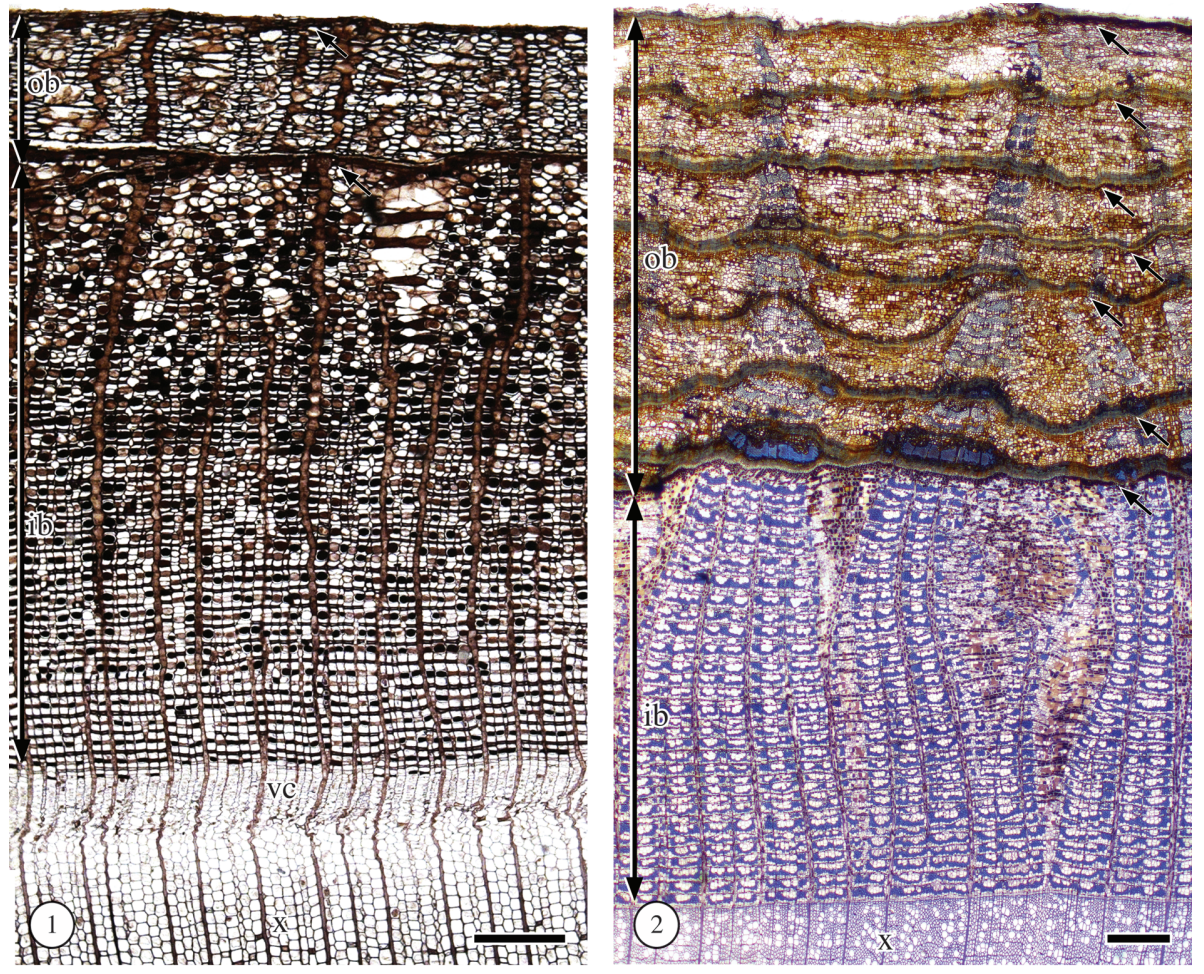

Figure 1 \& 2. - Bark, transverse sections. - 1: Bark of a gymnosperm. Sequoia sempervirens (Cupressaceae), rb/fc. - 2: Bark of an angiosperm. Tilia americana (Malvaceae), rb/fc. $1 \& 2$ : From the cambium to the outside inner bark (ib), which consists of the secondary phloem and the outer bark (ob). The outer bark is formed by sequent periderms (arrows), which enclose part of the nonconducting phloem, constituting a rhytidome. $-\mathrm{x}=\mathrm{xylem}, \mathrm{vc}=$ vascular cambium. - Scale bars for $1=250 \mu \mathrm{m}$; for $2=500 \mu \mathrm{m}$. 


\section{Secondary phloem}

Definition: The phloem tissue derived from the vascular cambium, composed of conducting and nonconducting phloem.

\section{Conducting and nonconducting phloem}

\section{Conducting phloem}

Definition: Portion of the secondary phloem adjacent to the cambium recognized by living sieve tubes/sieve cells with turgid companion cells/Strasburger cells (fig. $3 \& 4$ ). Comments: This part corresponds to the functioning phloem, in which the sieve elements conduct photosynthates. The phloem is conductive usually for just one growing season, but can remain functional for two or more seasons. Longitudinal sections should be consulted for cellular contents of the sieve elements.
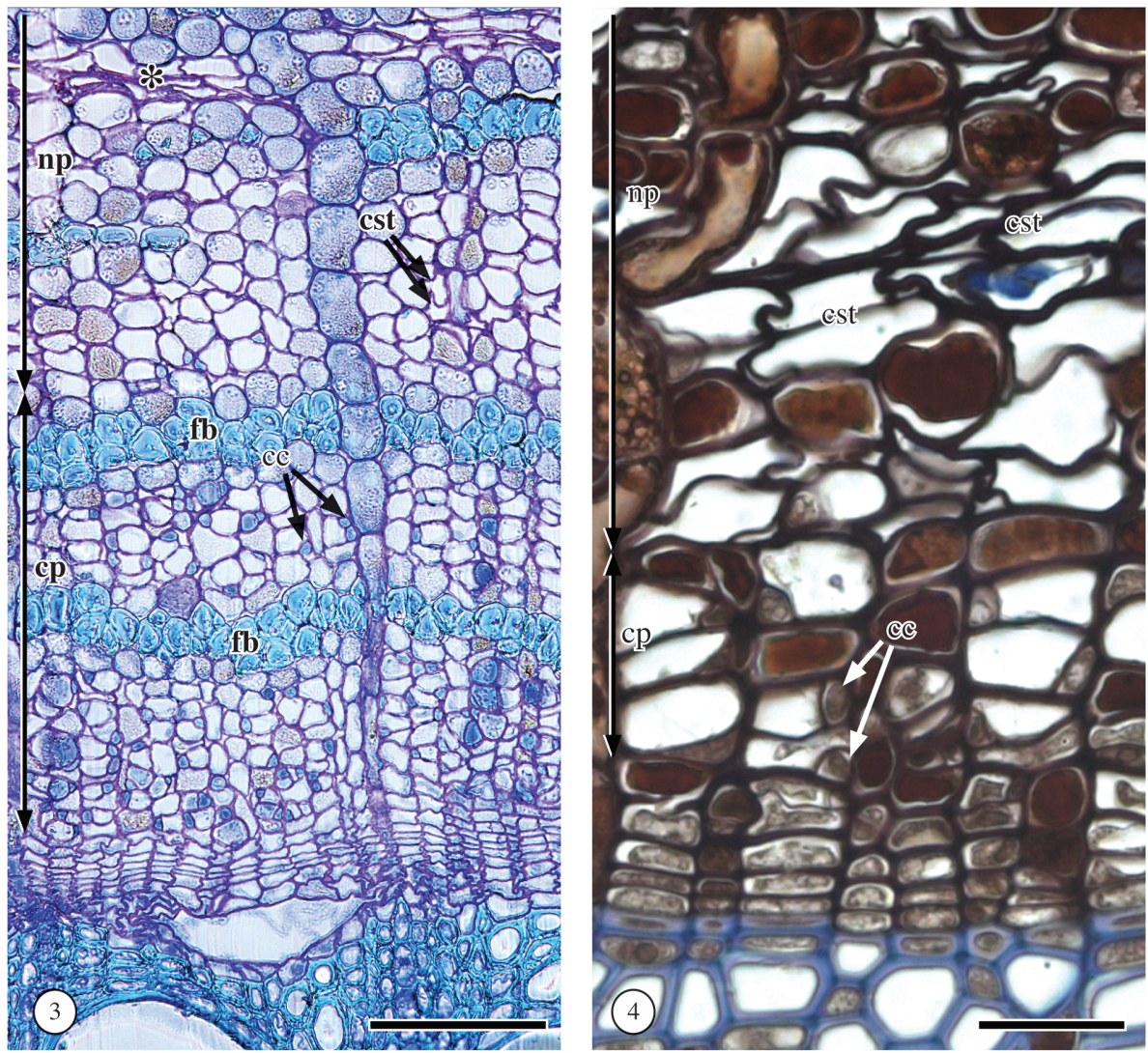

Figure 3 \& 4. - Conducting and nonconducting phloem, transverse sections. Conducting phloem (cp) with sieve tubes turgid, accompanied by equally turgid and dark stained companion cells (cc). Nonconducting phloem (np) marked by collapsing (cst) or totally collapsed (asterisk) sieve tubes. - 3: Bignonia magnifica (Bignoniaceae), tb. Large portion of conducting phloem, of about 20 cell rows $(\mathrm{fb}=$ fiber band). -4 : Alnus incana subsp. rugosa (Betulaceae), $\mathrm{rb} / \mathrm{fc}$. Narrow portion of conducting phloem, of about 4 cell rows. - Scale bars for $3=100 \mu \mathrm{m}$; for $4=50 \mu \mathrm{m}$. 


\section{Nonconducting phloem}

Definition: Portion of the secondary phloem recognized by sieve tubes/sieve cells with companion cells / Strasburger cells that have lost their cytoplasm and whose sieve elements are devoid of contents (fig. $3 \& 4$ ); definitive callose may be present at the sieve areas.

Comments: This part of the phloem has lost its conducting capacity. Other features, frequently associated with the nonconducting phloem, are collapse of the sieve elements (fig. 3), dilatation growth resulting from division and enlargement of parenchyma cells, sclerification, and the accumulation of secondary metabolites.

In the literature the terms "functional" vs "nonfunctional" and "collapsed" vs "noncollapsed" phloem have been used for conducting and nonconducting phloem (Esau 1969; Trockenbrodt 1990). We advise to avoid those terms, because a) clearly recognizable nonconducting phloem still continues to function in many other ways such as storage and mobilization of starch and other metabolites, and also as having meristematic capacity, e.g. to originate phellogen or dilatation tissue, and b) in many species sieve elements retain their shape for several years after they lose their conductive capacity (e.g., Tilia americana, Malvaceae; Eucalyptus, Myrtaceae).

\section{Sieve elements}

Definition: Cells in the phloem tissue bearing sieve areas on their walls, concerned with longitudinal transport of photosynthates throughout the plant body. Sieve elements are classified into gymnospermous sieve cells (page 542, fig. 29 \& 30) and angiospermous sieve-tube elements (fig. 5-8).

\section{Collapsed sieve elements}

Definition: Sieve elements that have been crushed and their structure made unrecognizable by growth adjustments within the tissue (fig. 7).

Comments: Groups of collapsed sieve elements together with collapsed associated parenchyma cells can give the impression of thick unlignified cell wall layers (fig. $3 \& 7$ ). In many species the nonconducting phloem is characterized by collapsed sieve elements; in others there is no obvious boundary between conducting and nonconducting phloem (Evert 2006).

\section{Sieve areas}

Definition: A portion of the sieve-element wall containing either scattered sieve pores (fig. 6) or sieve pores in clusters (fig. 8) through which the protoplasts of adjacent sieve elements are interconnected.

Comments: In angiosperms the pores on the lateral walls are smaller than those of the sieve plates. In the sieve cells of conifers the sieve areas are more numerous on the overlapping ends of the cells, and their pores are rather similar in size on all walls. 

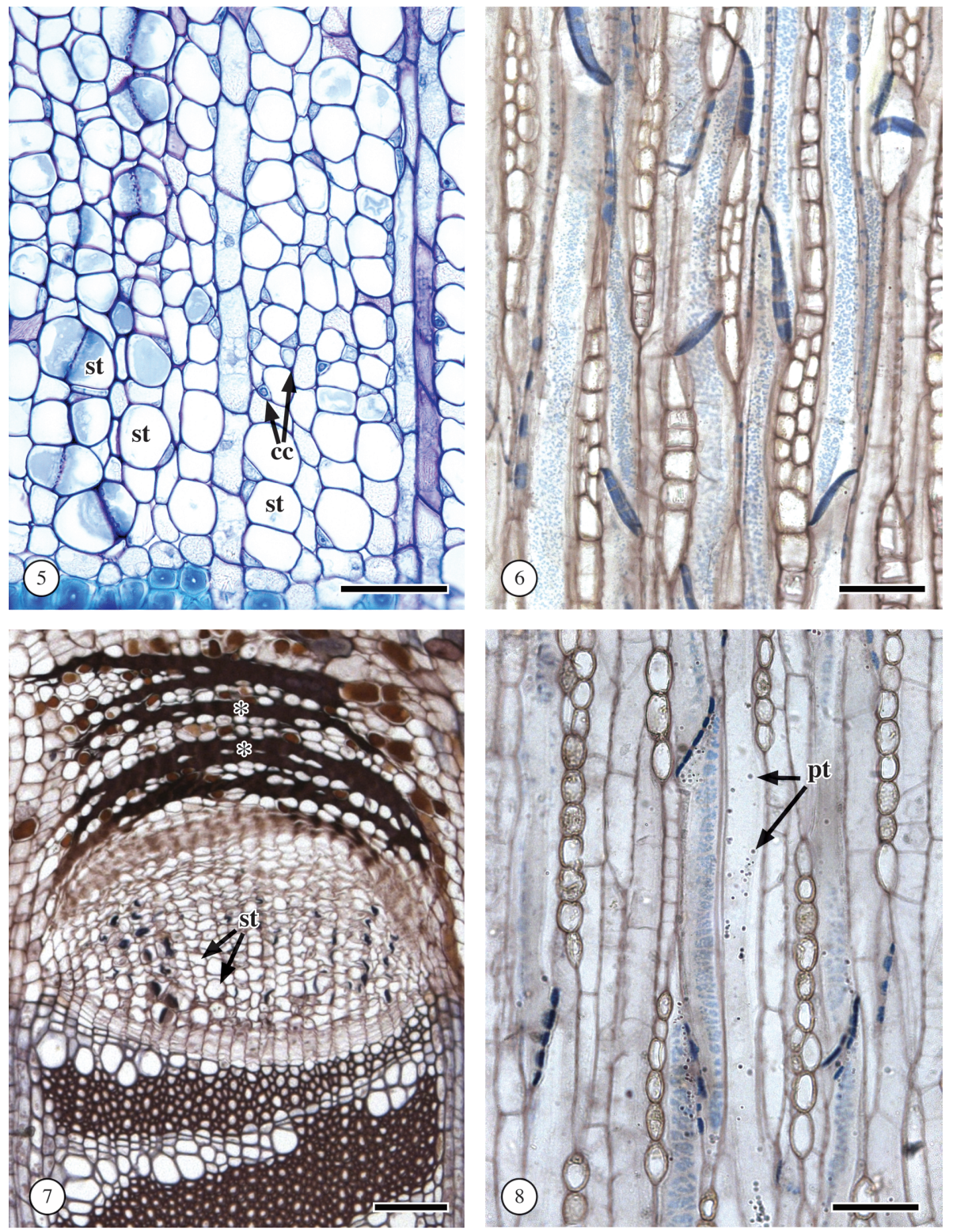

Figure 5-8. - Sieve-tube elements. - 5: Sieve-tubes (st) and their adjacent companion cells (cc), with dense cytoplasm and evident nuclei. Bignonia magnifica (Bignoniaceae), transverse section, tb. - 6: Sieve-tube elements with sieve plates inclined; lateral sieve-tube walls with scattered and minute pores. Cercidiphyllum japonicum (Cercidiphyllaceae), tangential section, rb/fc. 7: Sieve tubes (arrows) and their adjacent companion cells. Nonconducting phloem marked by totally collapsed sieve-tube elements (asterisks), alternating with noncollapsed axial parenchyma cells. Grevillea robusta (Proteaceae), rb/fc. - 8: Sieve-tube elements with sieve plates inclined, plastids (pt) evident. Lateral sieve-tube walls with pores clustered in sieve areas. Castanea dentata (Fagaceae), tangential section, rb/fc. - Scale bars for 5, $6 \& 8=50 \mu \mathrm{m}$; for $7=100 \mu \mathrm{m}$. 


\section{Angiosperms}

\section{Sieve tubes and companion cells}

Sieve-tube element (syn. sieve-tube member)

Definition: Elongate phloem cell, characterized by the presence of sieve plates with wide pores and lateral sieve areas with narrow pores; one of the components of a sieve tube (fig. $6 \& 8$ ).

Comment: Sieve-tube elements are associated ontogenetically and functionally with companion cells (fig. 5 \& 7).

\section{Sieve tube}

Definition: A series of sieve-tube elements arranged end-to-end and interconnected by sieve plates (fig. $6 \& 8$ ).

Sieve-tube grouping and distribution (to be determined in the conducting phloem)

1. Solitary and in small groups - Some tubes in pairs or groups of three, others solitary and scattered among other cell types (fig. 9).

2. In radial rows - Arranged in radial rows of 3-4 or more sieve tubes (fig. 10).

3. In tangential bands - Arranged in tangential bands of solitary and multiples of 2-4 or more sieve tubes and associated parenchyma cells (fig. 11).

4. In clusters - Arranged in more or less isodiametric groups of 3-4 or more sieve tubes (fig. 12).

Comment: In some species the tangential bands of sieve tubes alternate with tangential bands of fibers (fig. 11).

\section{Sieve plates}

Definition: Part of the sieve-tube element wall bearing highly differentiated sieve areas (fig. 13-18).

\section{Types of sieve plates}

Simple: Sieve plate composed of one sieve area (fig. $13 \& 14$ ).

Scalariform: Compound sieve plate with elongated sieve areas in a ladder-like arrangement (fig. 16-18).

Reticulate: Compound sieve plate with sieve areas arranged in a more or less netlike pattern (fig. 15).

\section{Sieve plate complement}

5. All sieve plates simple (fig. $13 \& 14$ )

6. Simple and scalariform or reticulate (compound) plates present

7. All sieve plates scalariform

8. Scalariform plates with $<\mathbf{1 0}$ sieve areas (fig. 16)

9. Scalariform plates with $\geq \mathbf{1 0}$ sieve areas (fig. $17 \& 18$ )

10. Reticulate sieve plates present (fig. 15) 

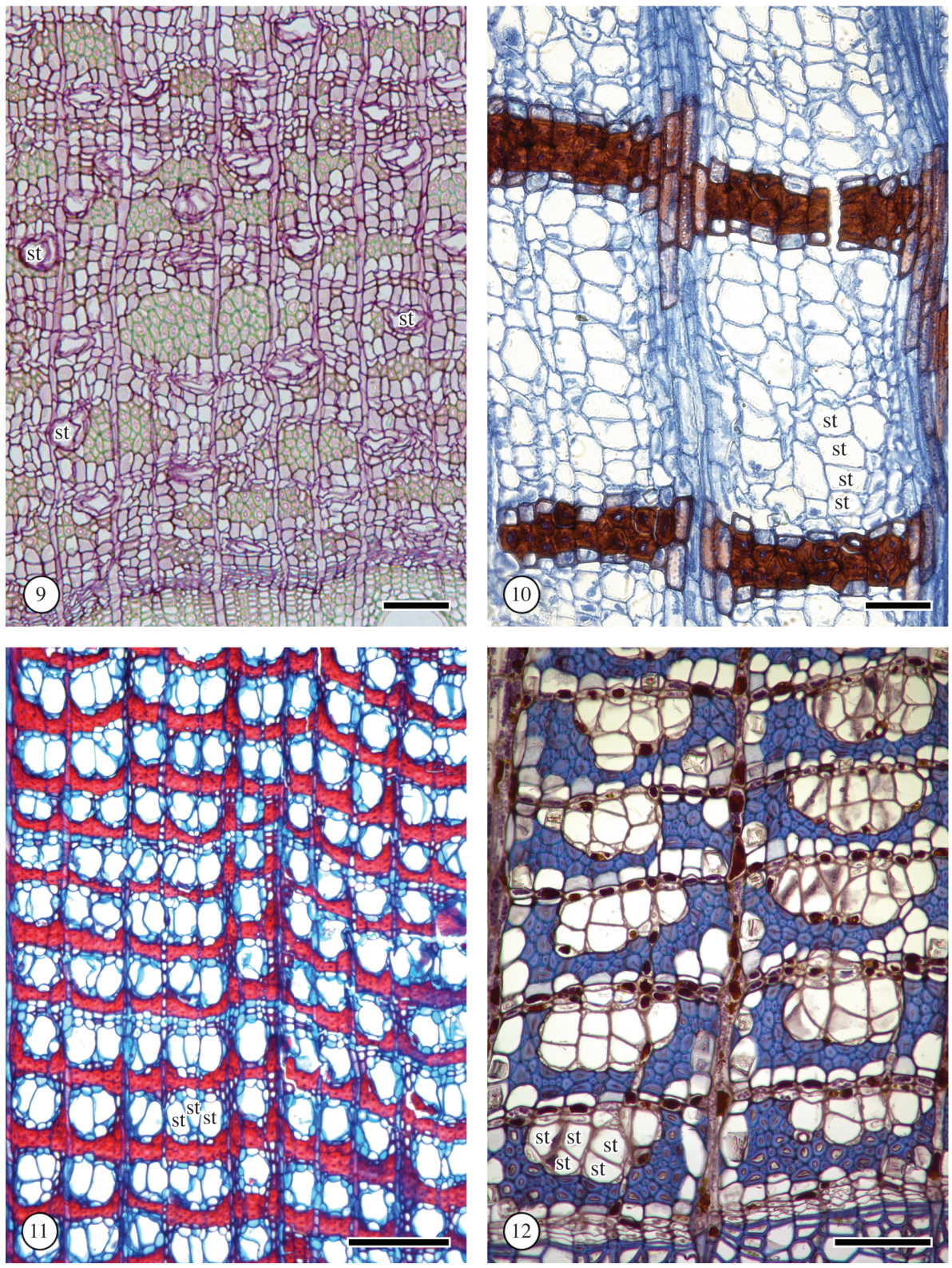

Figure 9-12. - Sieve-tube grouping and distribution, transverse sections. - 9: Sieve tubes soli-tary (st) or in groups of two to three. Eucalyptus globulus (Myrtaceae), h/mg. - 10: Sieve tubes (st) arranged in radial rows. Mansoa difficilis (Bignoniaceae), ab/s. - 11: Sieve tubes (st) arranged in tangential bands, solitary or in groups of two to three, Fridericia triplinervia (Bignoniaceae), ab/s. - 12: Sieve tubes (st) in clusters. Tilia americana (Malvaceae), rb/fc. - Scale bar for 9, $10 \& 12=100 \mu \mathrm{m}$; for $11=200 \mu \mathrm{m}$. 

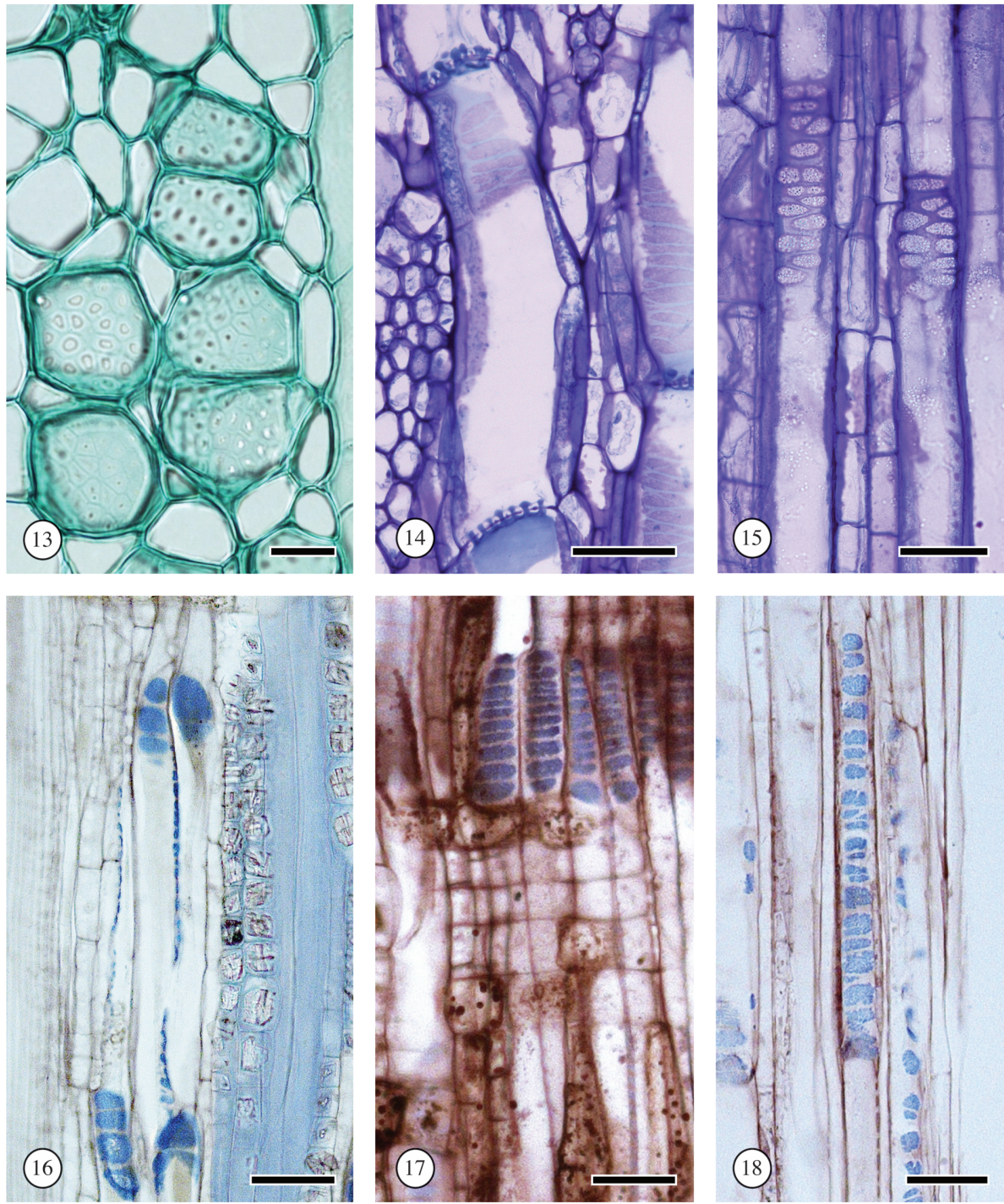

Figure 13-18. - Sieve plates. - 13: Simple sieve plates. Ficus lapathifolia (Moraceae), transverse section, fg/s. - 14: Simple sieve plates. Ficus benjamina (Moraceae), tangential section, tb. - 15: (More or less) reticulate sieve plates. Entada polystachya (Leguminosae), radial section, tb. - 16: Scalariform sieve plate with less than 10 sieve areas. Strongly inclined sieve plate. Quercus alba (Fagaceae), radial section, rb/fc. - 17: Scalariform sieve plate with $\geq 10$ sieve areas. Strongly inclined sieve plate. Juglans hindsii (Juglandaceae), radial section, rb/fc. - 18: Scalariform sieve plate with over 10 sieve areas. Strongly inclined sieve plate. Polyscias murrayi (Araliaceae), radial section, rb/fc. - Scale bar for $13=20 \mu \mathrm{m}$; for $16=$ $40 \mu \mathrm{m}$, for $14,15,17 \& 18=50 \mu \mathrm{m}$. 
Comments: Scalariform and reticulate sieve plates are jointly also called compound plates. The combined occurrence of simple and scalariform plates in the same taxon is much more common in barks than the combined occurrence of simple and scalariform perforations in secondary xylem. The number of sieve areas per sieve plate is an informative character for some plant groups, but can also be highly variable within a sample, which should then be coded for both features 8 and 9 . Numerous sieve-tube elements should be observed before a species can be characterized as having exclusively scalariform or simple plates or a certain number (range) of sieve areas.

Reticulate sieve plates have been reported in the literature (Esau 1969) and were found by us in a number of taxa but are of rare occurrence. These compound plates are often more or less reticulate, not strictly so, and may intergrade with scalariform plates. Sieve plates of this type have been seen in several mimosoid Legumes (e.g., Entada polystachya, Leucaena leucocephala, Mimosa velloziana).

Sieve plate inclination: Angle of the end wall relative to the vertical axis as seen in TLS. Simple sieve plates composed of single sieve areas commonly occur on more or less transverse end walls. Compound sieve plates are characteristic of the longer and more inclined end walls.

11. Transverse and/or slightly inclined (fig. $13 \&$ 14)

12. Strongly inclined (fig. 15-18)

Comment: (Nearly) transverse end walls are at angles of $>60-90^{\circ}$ to the vertical axis; strongly inclined end walls are at angles much less than $60^{\circ}$ to the vertical axis.

\section{P-protein, slime and callose}

\section{P-protein}

Definition: Phloem-protein; a proteinaceous substance found almost exclusively in sieve-tube elements (formerly called slime).

Comment: P-protein can be present either as dispersive P-protein bodies, eventually deposited in a parietal position, but forming slime plugs upon disturbance, and nondispersive P-protein bodies (Behnke 1991; Evert 2006), as conspicuous in for instance papilionoid legumes and Boraginaceae (Behnke 1991) (fig. 19).

\section{Slime plug}

Definition: An accumulation of P-protein on a sieve plate (fig. 19, 26), usually with extensions to the sieve plate pores (Evert 2006) (fig. 27).

\section{Callose}

Definition: A cell wall polysaccharide ( $\beta-1,3$ glucan) in the sieve areas of sieve elements; common constituent of sieve elements. Callose also develops rapidly in response to injury (fig. 19). In the nonconducting phloem definitive callose may occur, blocking the sieve area pores (fig. 20) (Evert 2006).

Comment: Since microtechnical procedures result in injury, callose in the conducting phloem is always wound callose (fig. 19). 

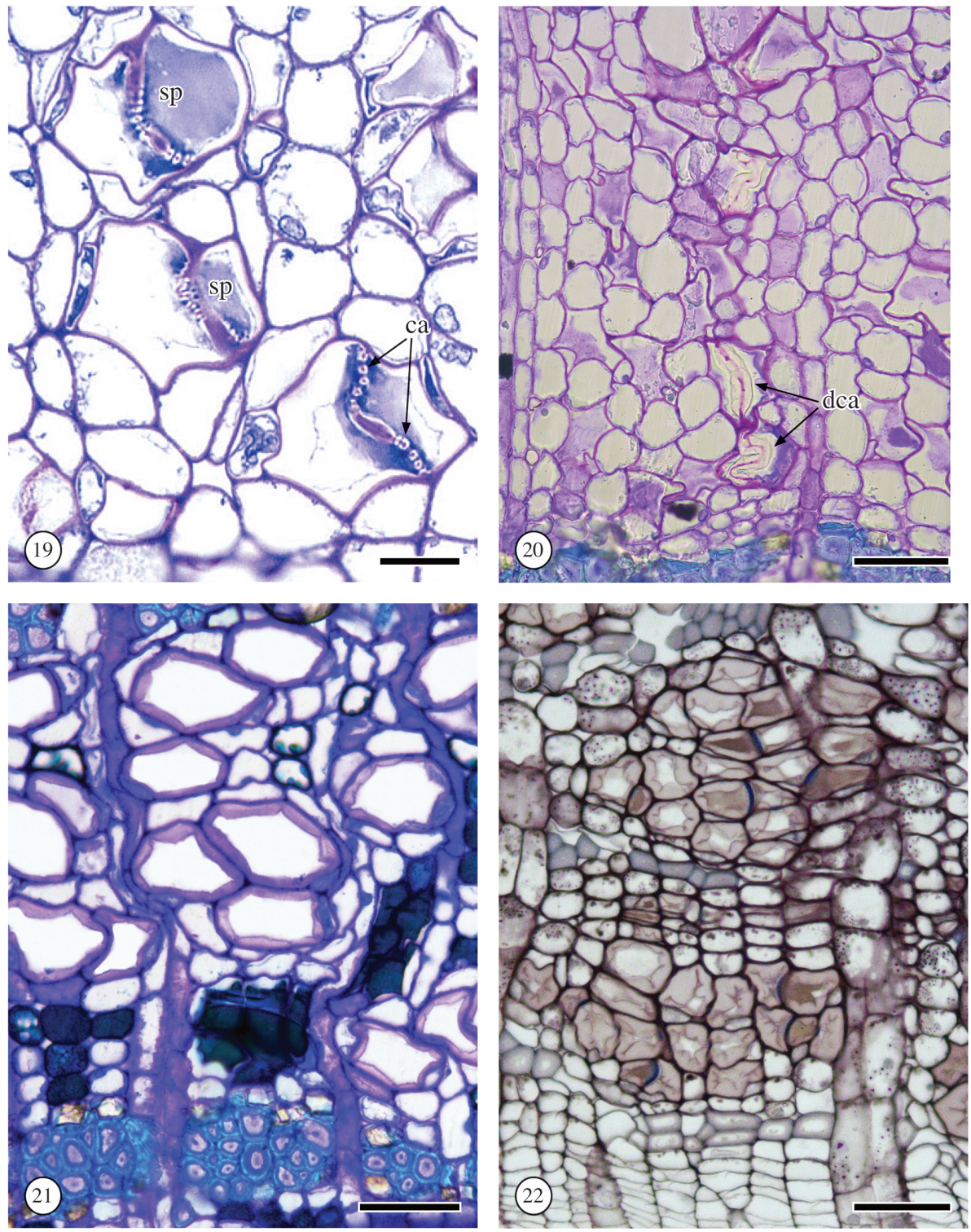

Figure 19-22. - 19: Sieve-tube elements with P-protein forming a slime plug (sp) in the sieve plates. Wound callose lining the pores (ca; bright aspect, arrow). Cordia trichotoma (Boraginaceae), by courtesy of Erika Amano, tb. - 20: Sieve-tubes with massive definitive callose (dca) at sieve plates. Amphilophium crucigerum (Bignoniaceae), tb. - 21 \& 22: Sieve tubes with nacreous walls. - 21: Gouania blanchetiana (Rhamnaceae), tb. -22 : Magnolia kobus (Magnoliaceae), rb/fc. $-19-22$ : transverse sections. - Scale bar for $19=20 \mu \mathrm{m}$, for 20, $21 \&$ $22=50 \mu \mathrm{m}$. 


\section{Sieve-tube plastids}

Definition: As per descriptor.

Comments: Plastids (fig. 8) are important components of sieve-tube protoplasts, and can best be studied at the ultrastructural level (Behnke \& Sjolund 1990; Evert 2006). There are two basic types: S-type (S, starch) and P-type (P, protein) that can be diagnostic for major clades in the angiosperms (Behnke 1991). The S-type occurs in two forms, one of which contains only starch, the other devoid of any inclusion. The P-type exists in six forms and contains one or two kinds of proteinaceous inclusions. Two of the six also contain starch. In sections, the plastids may be found accumulated at the sieve plates.

\section{Nacreous walls}

Definition: A nonlignified wall thickening that is often found in sieve elements and resembles a secondary wall when it attains a considerable thickness (Evert 2006) (fig. $21 \& 22$. )

Comments: The term nacreous is based on the glistening appearance of the wall in fresh tissue (Evert 2006). Esau \& Cheadle (1958) and Esau (1969) stressed the great variation in nacreous walls, depending on both developmental stages and plant group. Nacreous walls are consistently present in some taxa (e.g. Gouania, Rhamnaceae, many Annonaceae, Lauraceae, Magnoliaceae, and several Leguminosae).

14. Sieve-tube size (area and/or diameter, in TS; minimum-maximum, mean \pm standard deviation, $\mathrm{n}=\mathrm{x}$ )

Definition: As per descriptor.

Comments: In xylem anatomy, vessel frequency and vessel diameter are among the most well-documented features, because of their important roles in hydraulic functioning as well as their more limited diagnostic value (IAWA Committee 1989). The relevance of sieve tube size and frequency for the symplastic transport of photosynthates is also considerable.

In view of the irregular shape of sieve tubes we recommend to measure sieve-tube area rather than diameter (of at least 25 sieve tubes). Since most researchers are more familiar with diameter than area and the literature on cell dimensions always shows diameter, the corrected diameter of sieve tubes can be obtained through the equation $d=2 . \sqrt{ }(a / \pi)$ (in which a $=$ sieve-tube area and $d=$ diameter) (Mullendore et al. 2010). Admittedly, this introduces a source of error, varying with the actual shape of the sieve tubes.

15. Sieve-tube element length (minimum-maximum, mean \pm standard deviation, $\mathrm{n}=\mathrm{x}$ )

Definition: As per descriptor.

Comments: Measure the sieve tube elements in tangential sections of the conducting phloem, maximum length from tip to tip. Observation of individual sieve-tube elements in macerations is possible, but we do not recommend this because of frequent deformation. 

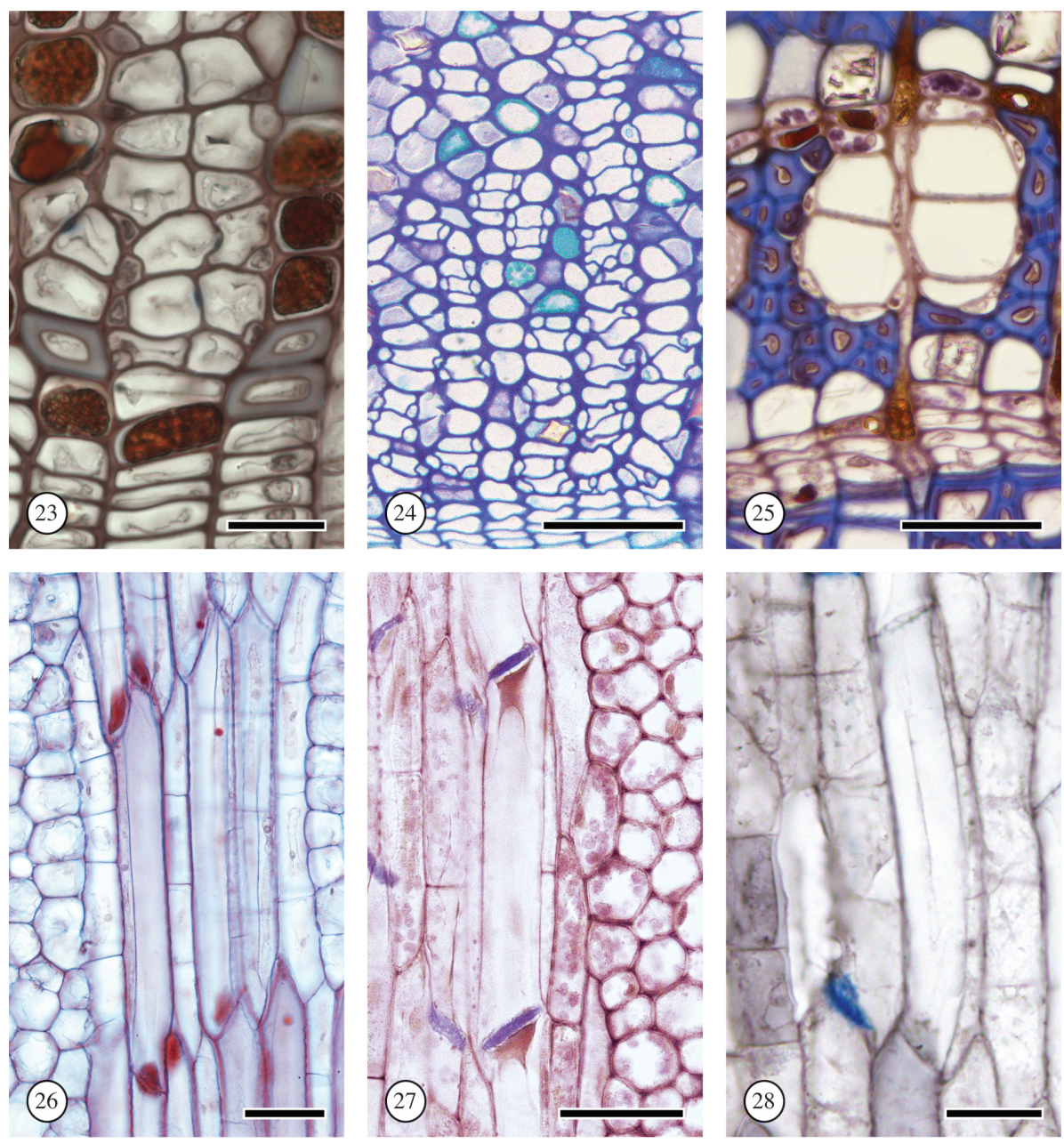

Figure 23-28. - Companion cells, as seen in transverse (23-25) or tangential section (26-28). -23: One companion cell (cc) per sieve tube. Machilus nanmu (Lauraceae), rb/fc. - 24: Two companion cells lying on opposite sides of the sieve tubes. Ficus pumila (Moraceae), tb. - 25: Two or more companion cells along the sieve tubes. Tilia americana (Malvaceae), rb/fc. -26 : Companion cell (cc) fusiform. Slime plugs at the sieve plates. Brachychiton (Malvaceae), rb/fc. 27: Companion cells (cc) in strands of two cells. Slime plugs with extensions (brown-red). Cordia caffra (Boraginaceae), rb/fc. - 28: Companion cells (cc) in strands of three cells. Robinia pseudoacacia (Leguminosae), rb/fc. - Scale bar for $23 \& 28=20 \mu \mathrm{m}$; for $24-27=50 \mu \mathrm{m}$.

\section{Companion cells}

Definition: A companion cell is a specialized parenchyma cell associated with a sievetube element and derived from the same mother cell as the sieve-tube element (fig. 23-28).

Comments: Companion cells have only been reported in angiosperms and constitute a synapomorphy for this large clade of vascular plants. Their main function is the main- 
tenance of their associated, enucleate, sieve-tube elements, and loading and unloading of sieve-tube elements. In the conducting phloem the companion cells are turgid and, in transverse section, typically appear in the corners of the sieve-tube elements (fig. $23,26,28)$.

Companion cells usually have a dense cytoplasm, but in some species they can be considerably vacuolated. In the nonconducting phloem the companion cells first lose their cytoplasm and after that typically collapse when their associated sieve-tube elements cease to function and therefore are difficult to discern. Very rarely companion cells can become sclerified in old phloem (Brook 1951; Evert 1963a). Companion cells associated with sieve-tube elements are also present in angiosperms with vesselless wood such as Trochodendraceae (original observation) and Winteraceae (Esau \& Cheadle 1984).

\section{Number of companion cells per sieve-tube element}

As seen in TS

16. One companion cell (fig. 23)

17. Two companion cells, lying on opposite sides of the sieve tube (fig. 24)

18. Two or more companion cells lying along the sieve tube (fig. 25) As seen in RLS or TLS

19. Companion cells fusiform: the companion cells have the same length as the sieve element or may be shorter, and are not subdivided (fig. 26)

20. Companion cells in strands of 2 cells (fig. 27)

21. Companion cells in strands of $>2$ cells (fig. 28)

Definition: As per descriptors.

Comments: The diagnostic value of the different character states remains to be evaluated. Within a single plant the number of companion cells may vary with the age of the plant (Esau 1969).

\section{Gymnosperms}

\section{Sieve cells}

Definition: Sieve elements found in the phloem of gymnosperms with sieve areas of uniform (narrow) pore size on all walls; lacking sieve plates (fig. $29 \& 30$ ).

\section{Sieve cell size (area and/or diameter)}

\section{Sieve cell length}

Comment: Sieve cells can be measured in the same way as sieve-tube elements (see features 14 and 15).

\section{Strasburger cells}

Definition: Ray and axial parenchyma cells spatially and functionally associated with the sieve cells through sieve areas (fig. $31 \& 32$ ). Analogous to the companion cells of angiosperms but not originating from the same precursory cells as the sieve cells (Evert 2006). 

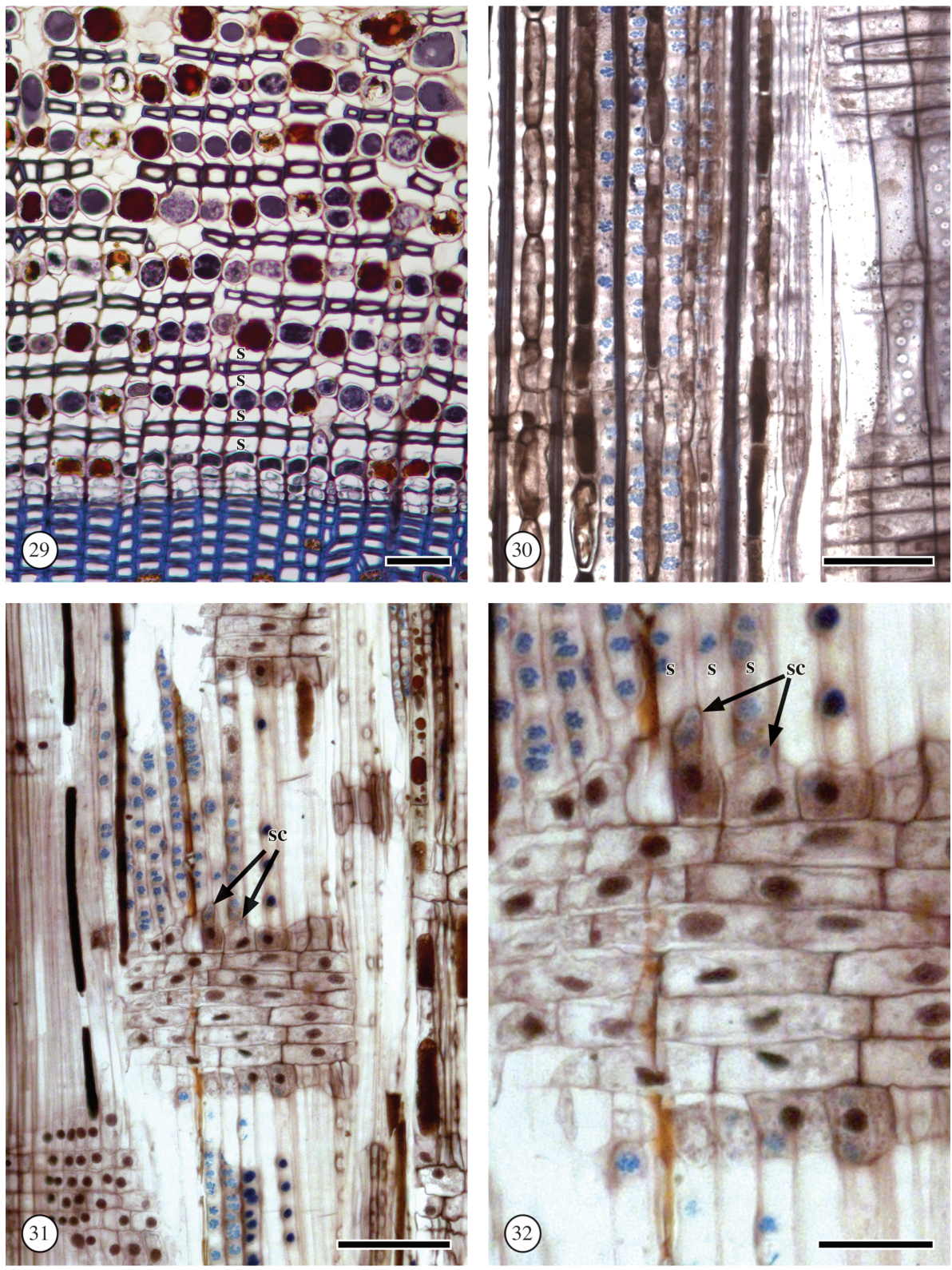

Figure 29-32. - Sieve cells and Strasburger cells, gymnosperms. - 29: Sieve cells (s) alternating with rows of fibers and axial parenchyma cells (with dark contents). Metasequoia glyptostroboides (Cupressaceae), transverse section, $\mathrm{rb} / \mathrm{fc} .-30$ : Sieve cells with lateral sieve areas stained blue, as seen in radial section. Taxodium distichum (Cupressaceae), rb/fc. -31 \& 32: Radial Strasburger cells in Pinus pinea (Pinaceae), radial sections, rb/fc. - 31: Strasburger cells (arrows) are in the ray margins. - 32: Strasburger cells in the rays have symplastic connections (sc), seen as smaller sieve areas, in contact with the sieve cells (s). - Scale bar for $30 \& 31=$ $100 \mu \mathrm{m}$; for $29 \& 32=50 \mu \mathrm{m}$. 
Comments: Strasburger cells in gymnosperms are the counterparts of the companion cells in angiosperms, and are distinguished from other parenchyma cells of the phloem by their symplastic connections with the sieve cells, seen as smaller sieve areas (fig. 32). They frequently have more densely staining protoplasts than other phloem parenchyma cells, but they are not always easy to distinguish. Like companion cells, Strasburger cells die when their associated sieve cell die. Presumably, the Strasburger cell plays a role similar to that of the companion cell: maintenance of its associated (enucleate) sieve element and its loading and unloading. We agree with Trockenbrodt (1990) that the synonymous term albuminous cell should be abandoned, because the assumption that they always have a high protein content is incorrect.

The distribution of Strasburger cells may vary from restricted to the ray cell or the axial phloem parenchyma to presence in both types of parenchyma, depending on the taxon. However, because Strasburger cells are often so difficult to recognize, especially in the axial system, we have refrained from recognizing individual character states for their distribution.

\section{Dilatation phenomena}

\section{Dilatation}

Definition: Increase in the circumference of the bark by parenchyma cell division and cell expansion (Fig. 33-36).

Comments: Dilatation is a process in which bark increases in circumference to adjust to the secondary growth of the xylem (adapted from Trockenbrodt 1990 and Evert 2006). The dilatation occurs in the secondary phloem, in the rays or the axial parenchyma or in both, and in the cortex and epidermis if persistent. Intercellular spaces can also be modified in shape and size during dilatation, especially in the cortex.

\section{Types of dilatation}

25. In the rays: the ray cells are tangentially expanded and/or undergo anticlinal division

\section{By cell expansion only (fig. 33)}

\section{By anticlinal cell division and cell expansion (fig. 34)}

Definition: As per descriptors. Feature 25 includes features 26 and 27 as subtypes. Comments: Ray dilatation is common in woody plants with multiseriate xylem and phloem rays, and often results in flaring or wedge-shaped rays (see page 550 under ray features) that are relatively narrow near the cambium and very broad towards the periphery of the bark. Sometimes the ray cell divisions are restricted in the median region of wedge-shaped rays and form a so-called dilatation meristem (Malvaceae s.l., fig. 34; Cordia trichotoma, Boraginaceae) and sometimes restricted to the ray margins (e.g. Amphilophium crucigerum, Bignoniaceae). In other species cell expansion and anticlinal cell divisions occur throughout the multiseriate ray. Dilating and nondilating rays often co-occur in both the conducting and nonconducting phloem. 

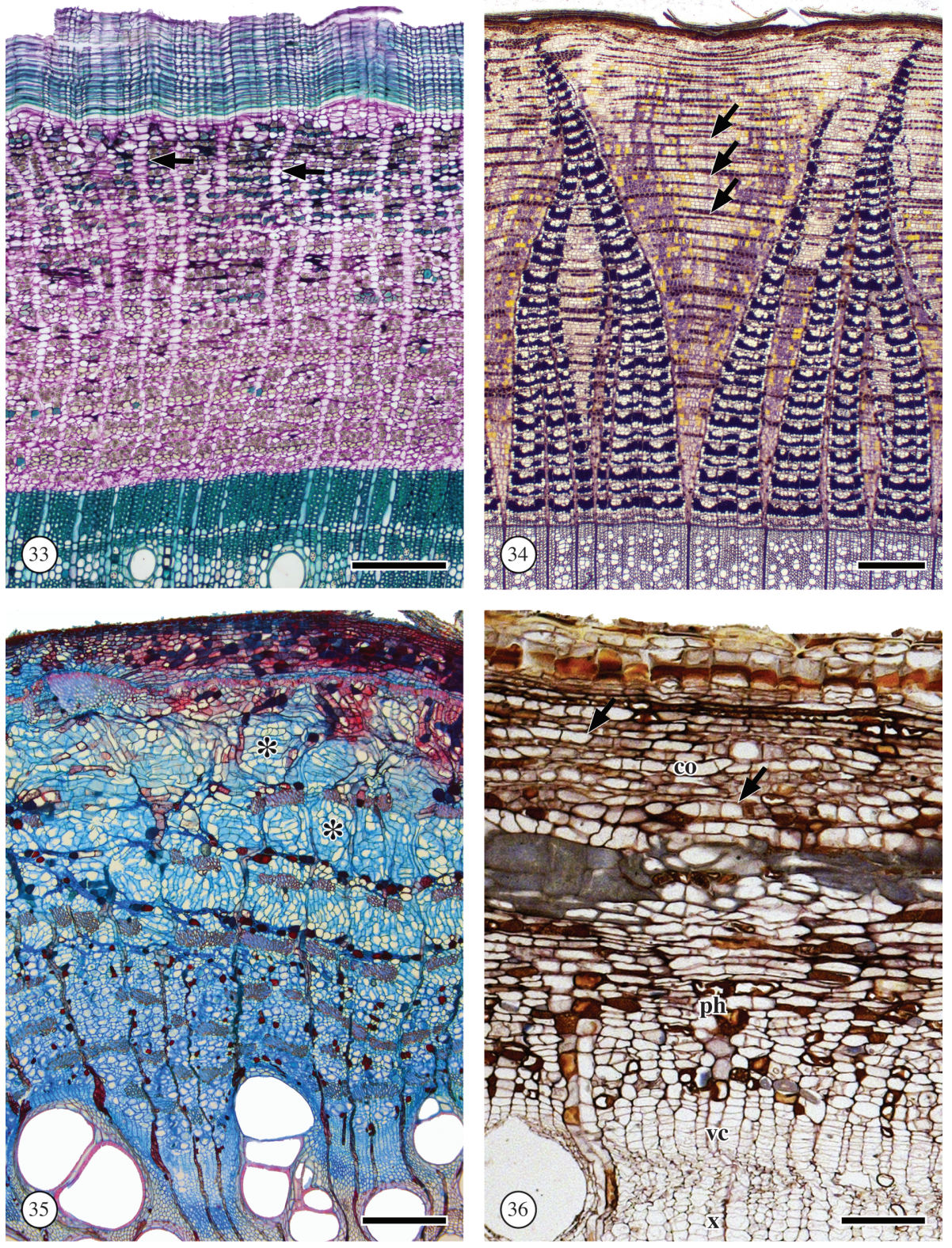

Figure 33-36. - Types of dilatation, transverse sections. - 33: Dilatation of the rays by cell expansion only (arrows). Terminalia guyanensis (Combretaceae), h/mg. - 34: Dilatation in central region of wedge-shaped rays by means of a dilatation meristem (arrows). Tilia americana (Malvaceae), rb/fc. - 35. Dilatation conspicuous in the axial parenchyma (*). Entada polystachya (Leguminosae), ab/s. - 36: Dilatation of cortical cells (co, arrows), and phloem (ph) axial and ray parenchyma, by both cell divisions and cell expansion. Litsea calicaris (Lauraceae), rb/fc. co $=$ cortex $; \mathrm{ph}=$ phloem; $\mathrm{vc}=$ vascular cambium, $\mathrm{x}=$ xylem. - Scale bar for $33 \& 35=$ $200 \mu \mathrm{m}$; for $34=500 \mu \mathrm{m}$; for $36=100 \mu \mathrm{m}$. 


\section{In axial parenchyma}

Definition: Dilatation through tangential expansion and/or anticlinal cell division of axial parenchyma (fig. 35).

Comments: Like in ray dilatation, the axial parenchyma dilatation through cell expansion and cell division may result in the formation of horizontal, tangential strands of parenchyma cells. Multiseriate rays are not conspicuously flaring or wedge-shaped in species with this type of bark dilatation. Axial parenchyma dilatation is the main form of dilatation in most conifer barks.

\section{In both axial parenchyma and rays}

Definition: Both the axial and ray parenchyma take part in dilatation (fig. 36).

Comment: The participation of both ray and axial parenchyma in the dilatation of the secondary phloem is common (e.g. Rhus typhina, Anacardiaceae), but equal participation of both cell types has been reported to be rare (Holdheide 1951).

30. In the cortex and/or epidermis: often the primary tissues remain present for a considerable period (e.g., Apiales), and then dilate through tangential cell expansion and anticlinal cell division (fig. 36).

\section{Axial parenchyma}

\section{Axial phloem parenchyma}

Definition: Parenchyma cells in the secondary phloem derived from fusiform initials of the vascular cambium.

Comments: Phloem parenchyma cells (axial and radial) characteristically retain their protoplasts at maturity, and, as long as their walls are unlignified, remain capable of dividing and expanding (Evert 2006). Fusiform cambial derivatives typically form transverse division walls, resulting in parenchyma strands. Here we do not consider the parenchyma of the phelloderm, derived from the phellogen or cork cambium, which does not produce fusiform cells or strands.

Other terms used to refer to axial phloem parenchyma: phloem parenchyma, bast parenchyma, bark parenchyma. Here we recommend the use of "axial phloem parenchyma" or simply "axial parenchyma" when describing the secondary phloem.

Parenchyma distribution (as seen in TS)

31. Diffuse and diffuse-in-aggregates. Axial parenchyma cells scattered among other cells of the secondary phloem, either solitary or in short discontinuous tangential or oblique aggregates (fig. 37).

32. Narrow bands. Axial parenchyma cells in discontinuous or continuous bands of 1(-2) cells wide (fig. 38).

33. Broad bands. Axial parenchyma cells in discontinuous or continuous bands of (2-)3 or more cells wide (fig. 40).

34. Sieve-tube-centric. Axial parenchyma cells around the sieve elements, in a complete or incomplete sheath (fig. 39). Typically found in species where the fibers form the ground tissue of the phloem (e.g. Carya, Juglandaceae, and Cuspidaria, Bignoniaceae).

35. Axial parenchyma constitutes the ground tissue (fig. 41). 

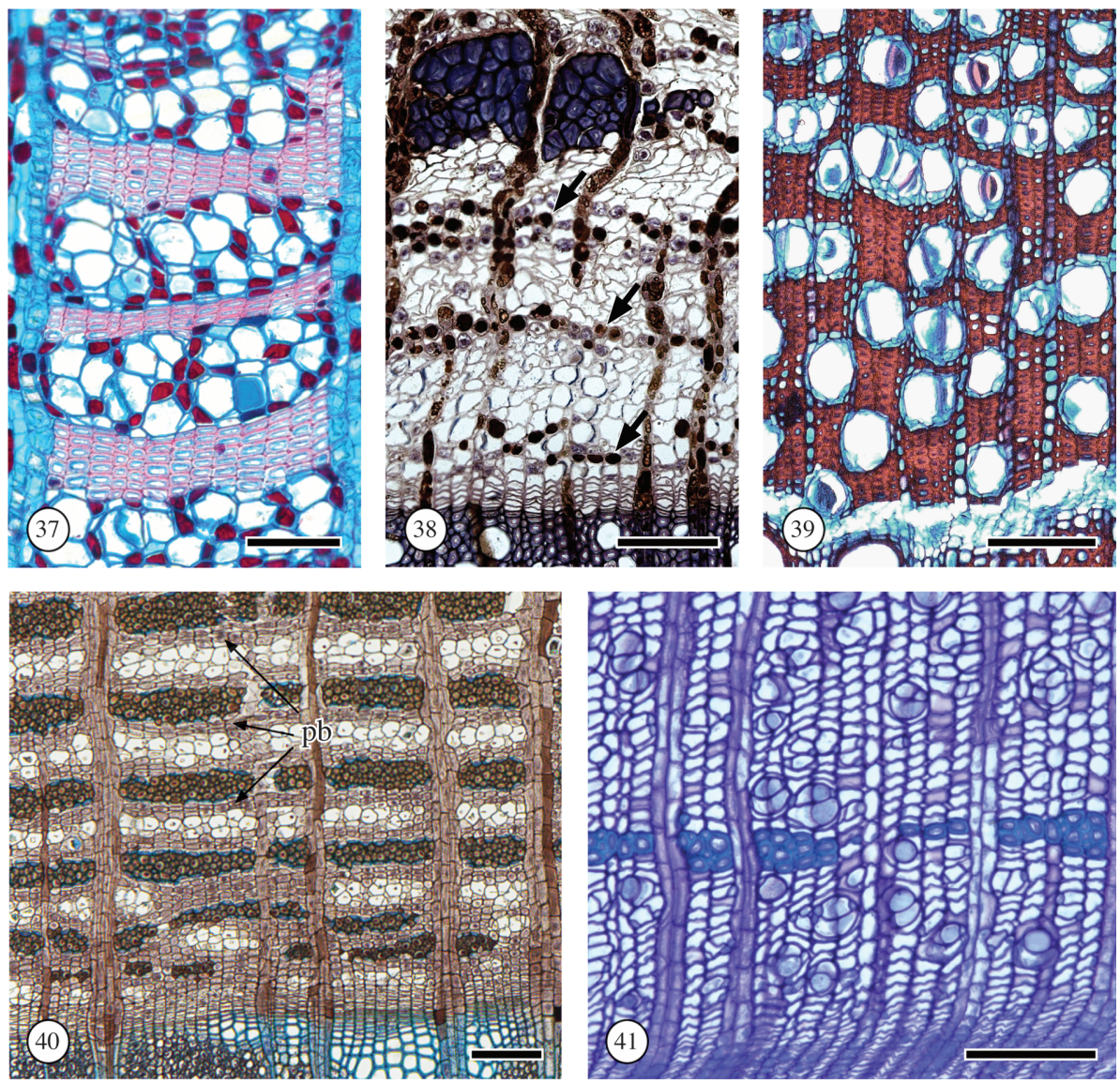

Figure 37-41. - Axial parenchyma distribution, transverse sections. - 37: Axial parenchyma (cells with colored contents) diffuse to diffuse-in-aggregates. Vitis bourgaeana (Vitaceae), ab/s. - 38: Axial parenchyma in narrow bands (arrows). Crataegus intricata (Rosaceae), $\mathrm{rb} /$ fc. - 39: Axial parenchyma sieve-tube-centric. Xylophragma myrianthum (Bignoniaceae), $\mathrm{ab} / \mathrm{s}$. - 40: Axial parenchyma in broad bands, 2-4 cells wide (pb, arrows). Robinia pseudoacacia (Leguminosae), rb/fc. - 41: Axial parenchyma forming the background tissue. Tecoma stans $($ Bignoniaceae), tb. - Scale bars $=100 \mu \mathrm{m}$.

Comments: Axial parenchyma associated with secretory canals is not included in this classification.

When recording parenchyma distribution, a distinction should be made between conducting and nonconducting phloem. Dilatation phenomena in nonconducting phloem, involving tangential cell expansion and anticlinal parenchyma cell divisions, as well as the obliteration of sieve elements may alter parenchyma distribution patterns significantly. For instance, species with diffuse or banded axial parenchyma and without fibers in the conducting phloem may develop nonconducting phloem in which parenchyma constitutes the ground tissue, due to the obliteration of the sieve tubes and companion cells. 
Although the character states defined above are partly inspired by the different patterns of parenchyma distribution in the secondary xylem, they can also be diagnostic in the secondary phloem. However, in the phloem the patterns are sometimes less easy to recognize, because axial parenchyma and sieve elements may resemble each other in TS.

\section{Parenchyma strand length}

Definition: Number of cells originating from one fusiform initial (as seen in TLS).

36. Fusiform or two cells per parenchyma strand (fig. $42 \& 43$ )

37. 3 or 4 cells per parenchyma strand (fig. 44)

38. 5-8 cells per parenchyma strand

39. Over eight cells per parenchyma strand (fig. 45)

Comments: In fusiform axial parenchyma the cambial derivatives remain undivided when differentiating into axial parenchyma, they are typical of storied structure and often co-occur with short parenchyma strands of two cells.

The above categories are almost identical to those for xylem parenchyma strand length. To our knowledge the diagnostic value of strand length remains to be tested in the secondary phloem.

\section{Other phloem parenchyma features}

For modifications of cell shapes and cell contents of phloem parenchyma see under dilatation (page 544), secretory structures (595), and mineral inclusions (588). These special kinds of parenchyma can be distinctive in their distribution and strand length from the "ordinary" phloem parenchyma (Kotina \& Oskolski 2010).
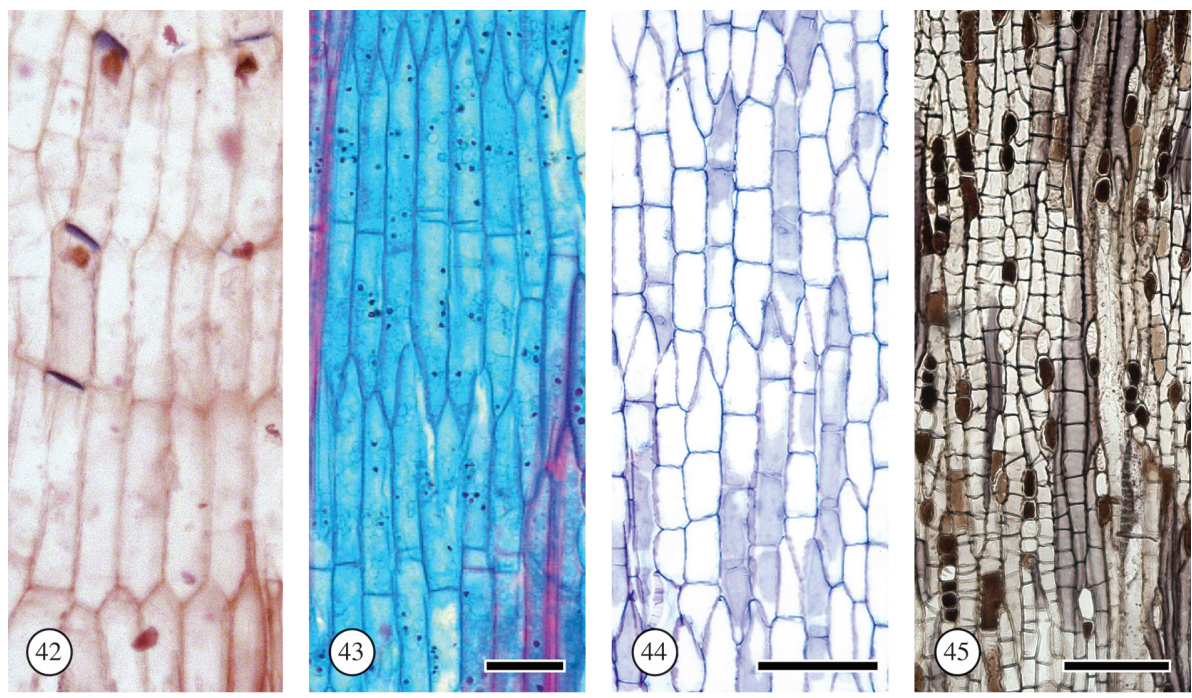

Figure 42-45. - Parenchyma strand length, tangential sections. - 42. Fusiform parenchyma cells. Erythrina lysistemon (Leguminosae), rb/fc. - 43. Two cells per parenchyma strand. Rhynchosia phaseoloides (Leguminosae), ab/s. - 44. Four cells per parenchyma strand. Amphilophium crucigerum (Bignoniaceae), ab/s. - 45. Over eight cells per parenchyma strand. Eucalyptus delegatensis (Myrtaceae), rb/fc. - Scale bar for $42-44=50 \mu \mathrm{m}$; for $45=100 \mu \mathrm{m}$. 

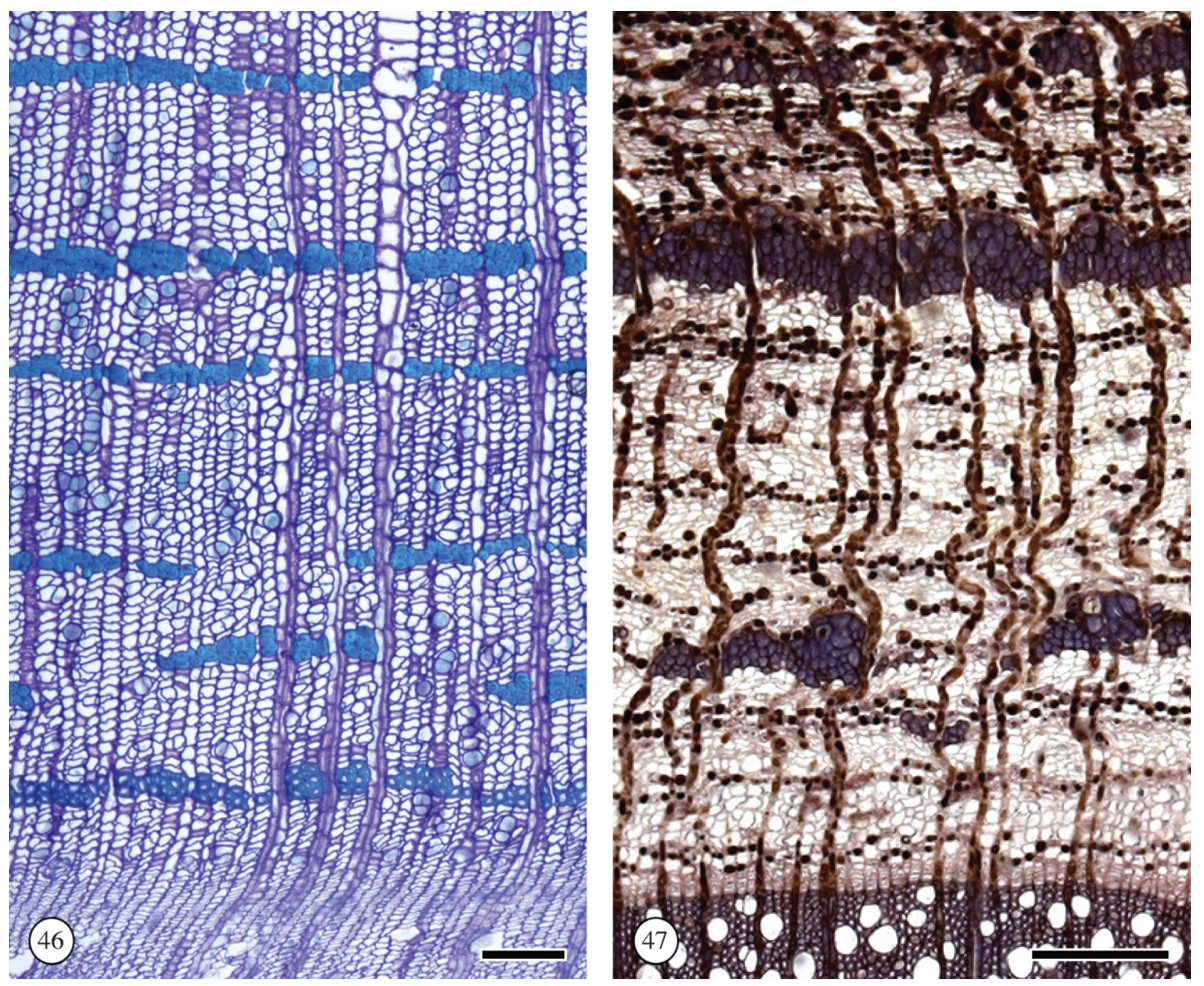

Figure $46 \& 47$. - Course of rays in nonconducting phloem, transverse sections. - 46: Course of rays straight. Tecoma stans (Bignoniaceae), tb. - 47: Course of rays undulated or wavy. Crataegus intricata (Rosaceae), rb/fc. - Scale bar for $46=100 \mu \mathrm{m}$; for $47=200 \mu \mathrm{m}$.

\section{Rays}

\section{Phloem ray}

Definition: A panel of parenchyma cells variable in height and width, formed by the ray initials in the vascular cambium and extending radially in the secondary phloem (Evert 2006).

Comments: The phloem rays are continuous with the xylem rays, since both arise from the same ray initials in the cambium. Therefore, near the cambium the phloem and xylem rays are usually similar in height, width and ray cell composition. The older (more peripheral) part of the phloem rays often increase in width (ray dilatation), sometimes to a considerably extent (e.g. in Malvaceae). Phloem ray width, the presence of rays of two distinct sizes and ray height classification are inspired by the ray classification in the xylem (IAWA Committee 1989).

Because phloem rays change dramatically during bark development due to the increase in circumference of the wood cylinder, the conducting phloem of mature stems represents character states that are more or less constant for a species. However, since conducting phloem is generally a small fraction of the entire secondary phloem, these character states are of limited value, especially if one has to characterize commercial 
bark samples, lacking the conducting phloem. Some ray features that may change dramatically outside the conducting phloem can therefore be considered "optional".

Rays in conifers show much less variation than in angiosperms. They are typically uniseriate in the conducting phloem and early nonconducting phloem, but some genera show dilatation towards the outer bark (Cedrus (Pinaceae), Cupressus, Juniperus, Fitzroya (Cupressaceae), Podocarpus (Podocarpaceae)). Rays in conifers may contain Strasburger cells (see page 542), as marginal, upright or square cells (fig. 31 \& 32); occasionally Strasburger cells occur in the middle of the ray (Esau 1969).

Course of rays (in the nonconducting phloem, as seen in TS)

40. Straight (fig. 46)

41. Undulated or wavy (fig. 47)

Definition: As per descriptor.

Comments: During development of the nonconducting phloem, rays may deviate from their straight course due to collapse of sieve tubes or expansion of other cells in the axial system resulting in a wavy or undulating course of the rays. According to Holdheide (1951) and Roth (1981) this can be diagnostic.

Ray dilatation (as seen in TS, see also page 544)

42. (Seemingly) Absent - ray width more or less constant throughout the conducting and nonconducting phloem (fig. 48)

43. Slightly dilated - some of the multiseriate rays flaring (irregularly funnelshaped) towards the outer bark (fig. 49)

44. Strongly dilated (wedge-shaped) - some of the multiseriate rays strongly broadening triangularly towards the periphery (fig. 50)

Comments: Strongly dilated rays always alternate with slightly or irregularly dilated or nondilated rays. Conspicuously wedge-shaped rays are typical of the order Malvales and several plant families from other groups (Metcalfe \& Chalk 1950; Esau 1969). The wedge-shaped rays may have lateral or central dilatation meristems of variable distinctness (see also page 546 in the chapter on dilatation). 

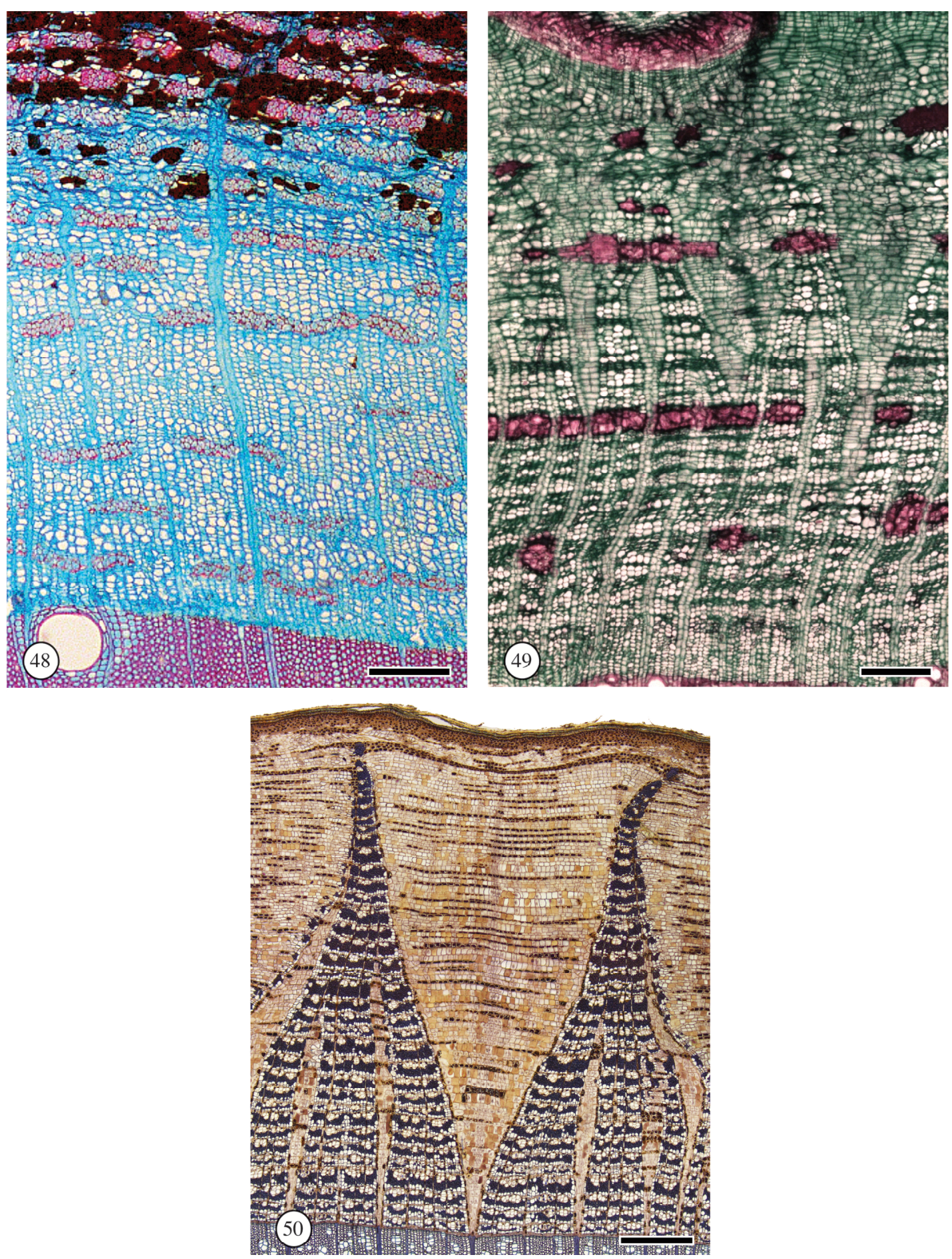

Figure 48-50. - Ray dilatation, transverse sections. - 48: Ray dilatation seemingly absent. Leucaena leucocephala (Leguminosae), ab/s. - 49: Rays slightly dilated. Harpalyce arborescens (Leguminosae), fg/s. - 50: Rays strongly dilated (wedge-shaped). Tilia americana (Malvaceae), rb/fc. - Scale for $48 \& 49=200 \mu \mathrm{m}$; for $50=400 \mu \mathrm{m}$. 
Ray width in cell number (as seen in TLS)

45. Rays exclusively uniseriate (fig. 51)

46. Rays 1 to 3 cells wide (fig. 52)

47. Larger rays commonly 4- to-10-seriate (fig. 53)

48. Larger rays commonly $>\mathbf{1 0}$-seriate (fig. 54)

49. Rays of two distinct sizes: when viewed in TLS rays form two distinct populations by their width and height (fig. 55)
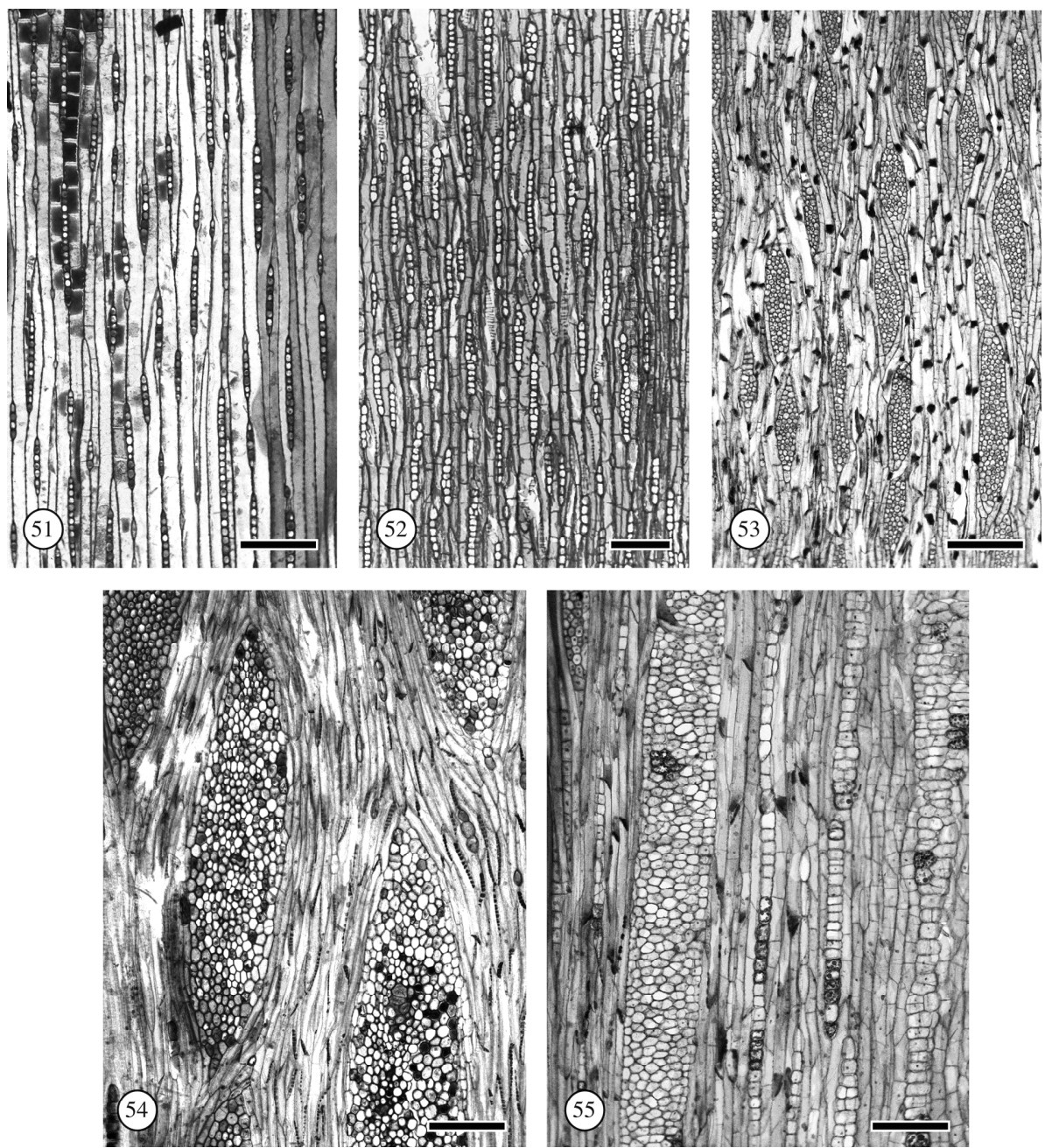

Figure 51-55. - Ray size, tangential sections. - 51: Rays exclusively uniseriate. Taxodium distichum (Cupressaceae). - 52: Rays 1 to 2 cells wide. Aspidosperma australe (Apocynaceae). 53: Larger rays commonly 4-10-seriate. Morus alba (Moraceae). - 54: Larger rays commonly more than 10 cells wide. Grevillea robusta (Proteaceae). - 55: Rays of two distinct sizes. Trochodendron aralioides (Trochodendraceae). - Scale bar for 51, $53 \& 55=200 \mu \mathrm{m}$; for 54 $\& 52=100 \mu \mathrm{m}$. 
Comments: Ray width must be determined in tangential sections by counting the number of cells in the widest part of the ray. Since ray dilatation may occur, ray width should be recorded in the conducting phloem. The classification is according to the IAWA Hardwood List categories for xylem rays; to be analyzed in the conducting phloem.

In species with flaring rays (see character 43), phloem ray width in the nonconducting phloem has little meaning, since it changes so much from the cambium outwards.

50. Ray height in $\mathbf{m m}$ (minimum-maximum, mean \pm standard deviation, $\mathrm{n}=\mathrm{x}$ ) to be measured in TLS in or near the conducting phloem

Definition: As per descriptor.

Comment: Although ray height remains more or less constant from the conducting to the nonconducting phloem, we recommend measuring it in the conducting phloem because the delimitation of rays from the axial tissues may be obscured in the outer bark due to dilatation phenomena in both the ray and axial parenchyma cells.

\section{Rays over $1 \mathrm{~mm}$ tall}

Definition: The large phloem rays commonly exceed $1 \mathrm{~mm}$ in height.

Comment: Presence or absence of tall phloem rays can be diagnostic - as it is in the secondary xylem (IAWA Committee 1989).

Ray composition (to be analyzed in the conducting phloem as seen in RLS)

52. All ray cells procumbent (fig. 56)

53. All ray cells upright (fig. 57)

54. Body ray cells procumbent with one to many rows of upright and/or square marginal cells (fig. 58)

55. Rays with procumbent, square and upright cells mixed throughout the rays (fig. 59)

Comments: The phloem rays may be composed of cells of similar shape, or they may contain procumbent, square and upright cells. The first ray type is named homocellular and the latter heterocellular (in the older literature referred as homogeneous and heterogeneous).

The above classification of ray cell composition partly mirrors that of xylem rays (IAWA Committee 1989). However, ray composition may change dramatically from the inner to the outer bark, as ray dilatation, compression and sclerification takes place. It is also related to cambial age and diameter of the stem or branch. For nonconducting phloem with its limited radial width this ray composition classification is hardly practical.

56. Sheath cells (as seen in TLS, fig. 60)

Definition: Ray cells that are located along the side of broad rays (more than 3-seriate) as viewed in tangential section and that are much larger than the central ray cells.

Comment: As in sheath cells in the secondary xylem, sheath cells in the phloem commonly arise from the conversion of fusiform initials into ray initials (Chattaway 1951). 

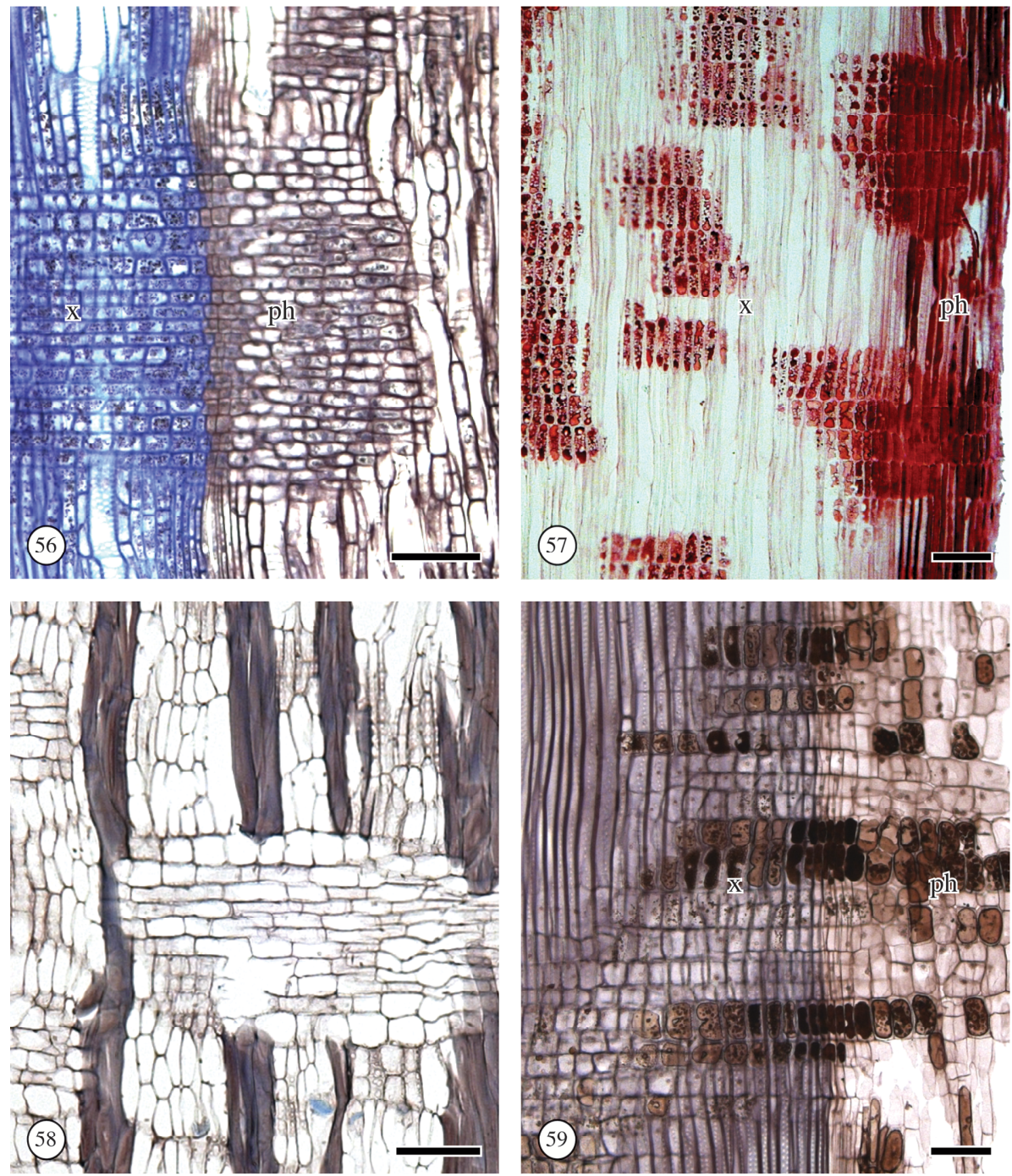

Figure 56-59. - Ray composition, radial sections. - 56: All phloem ray cells procumbent. Gymnocladus dioica (Leguminosae), rb/fc. - 57: All ray cells upright. Vaccinium corymbosum (Ericaceae), s. - 58: Body ray cells procumbent with one row of square marginal cells. Brachylaena transvaalensis (Asteraceae), $\mathrm{rb} / \mathrm{fc}$. -59 . Ray with procumbent, square and upright cells mixed throughout the rays. Drimys lanceolata (Winteraceae), $\mathrm{rb} / \mathrm{fc} .-\mathrm{x}=\mathrm{xylem}, \mathrm{ph}=$ phloem. Scale bars $=100 \mu \mathrm{m}$.

\section{Ray sieve-tube elements (as seen in TLS, RLS)}

Definition: Sieve-tube elements, either solitary on in groups, found in the phloem rays of some angiosperms (fig. 61-63).

Comments: Ray sieve-tube elements may serve to interconnect axial sieve tubes on either side of the ray (fig. 61), and are then analogous to perforated ray cells in the 

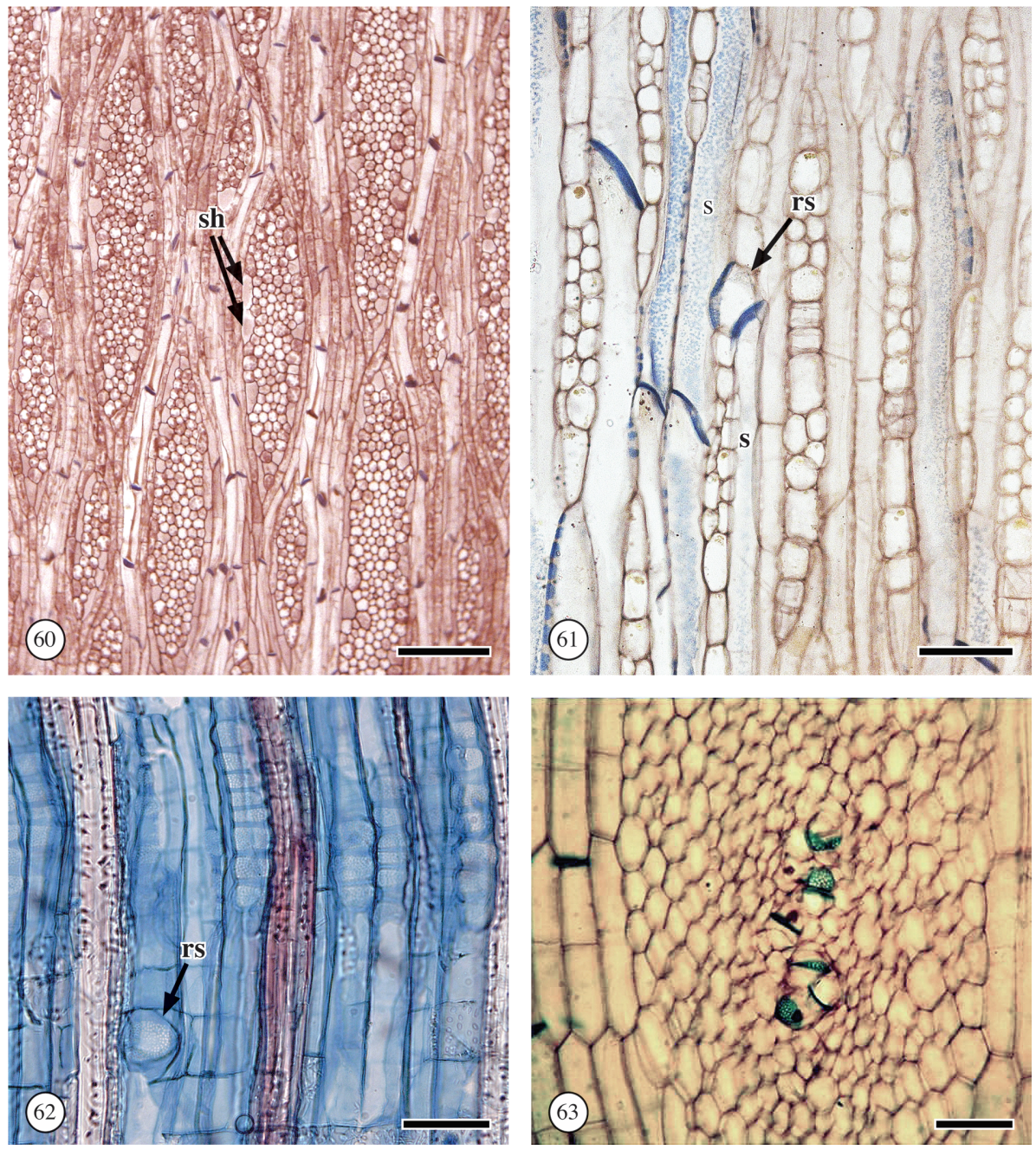

Figure 60-63. - 60. Sheath cells (sh). Cordia caffra (Boraginaceae), tangential section, rb/fc. 61: Ray sieve-tube element (rs), connecting two sieve-tubes (s). Cercidiphyllum japonicum (Cercidiphyllaceae), tangential section, rb/fc. - 62: Solitary ray sieve-tube element (rs). Amphilophium crucigerum (Bignoniaceae), radial section, ab/s. - 63: Ray sieve-tube elements forming groups. Erythrina indica (Leguminosae), tangential section, by courtesy of Kishore Rajput, $\mathrm{rb} / \mathrm{fc}$. - Scale bar for $60=200 \mu \mathrm{m}$; for $61-63=50 \mu \mathrm{m}$.

secondary xylem. Radially arranged sieve-tube elements may also occur within some multiseriate phloem rays (cf. Rajput 2004; fig. 63). In some species with perforated ray cells, ray sieve-tube elements are also present in the phloem (e.g., in the lianas Stizophyllum riparium and Dolichandra unguis-cati (Bignoniaceae) (Angyalossy et al. 2012; Pace et al.2015), and the treelet Styrax camporum (Styracaceae). 
58. Aggregate rays (to be observed in TS and/or TLS)

Definition: A number of individual rays, so closely associated with one another, that they appear as a single large ray (modified from aggregate wood rays, IAWA Committee 1989) (fig. 64-67).

Comments: There is variation in the size of individual rays: in some species the aggregate rays are composed of narrow rays (fig. $64 \& 65$ ); in others of broad rays (fig. 66 \& 67). Taxa with aggregate xylem rays also have aggregate phloem rays in the conducting phloem (e.g. Alnus, Carpinus, Corylus, Betulaceae). Dilatation and sclerification of the aggregate ray complex is usually stronger than in the intervening phloem portions (Holdheide 1951).

Sclerification of rays (see also Sclerenchyma, page 560)

Definiton: Some or all ray cells in the nonconducting secondary phloem sclerified (i.e. with thick, lignified, polylamellate walls).

59. Absent (fig. 68)

60. Ray cells sclerified only when touching axial sclerenchyma cells (fig. 69)

61. Central or scattered groups of ray cells sclerified (fig. 70)

62. (Almost) all ray cells sclerified (fig. 71)

Comments: Sclerification in rays can be highly diverse, and may develop over a long period of time in the nonconducting phloem (Esau 1969). Sclerification of ray cells in contact with fibers or sclereids is typical for e.g. Alnus (Betulaceae), Morus (Moraceae) and Pyrus (Rosaceae; Holdheide 1951). Groups of sclereids develop for instance in broad rays of Quercus (Fagaceae; Esau 1969), several Menispermaceae (Tamaio 2006) and Karelian birch (Betula pendula and B. pubescens, Betulaceae).

\section{Phloem rayless}

Definition: Phloem with only axial parenchyma and other axial elements (fig. $72 \& 73$ ). Comment: Secondarily woody taxa with rayless woods (e.g. some Brassicaceae, Amaranthaceae (including Chenopodiaceae), Caryophyllaceae, Frankeniaceae, Scrophulariaceae) may also lack rays in the secondary phloem (Carlquist 2001; Lens et al. 2009, 2013; Crivellaro \& Schweingruber 2013).

\section{Other ray features}

Tile cells - Tile cells, which are a highly diagnostic feature in xylem anatomy of the Malvales, do not occur in the secondary phloem as far as known (Chattaway 1933), and confirmed by original observations (fig. $74 \& 75$ ). 

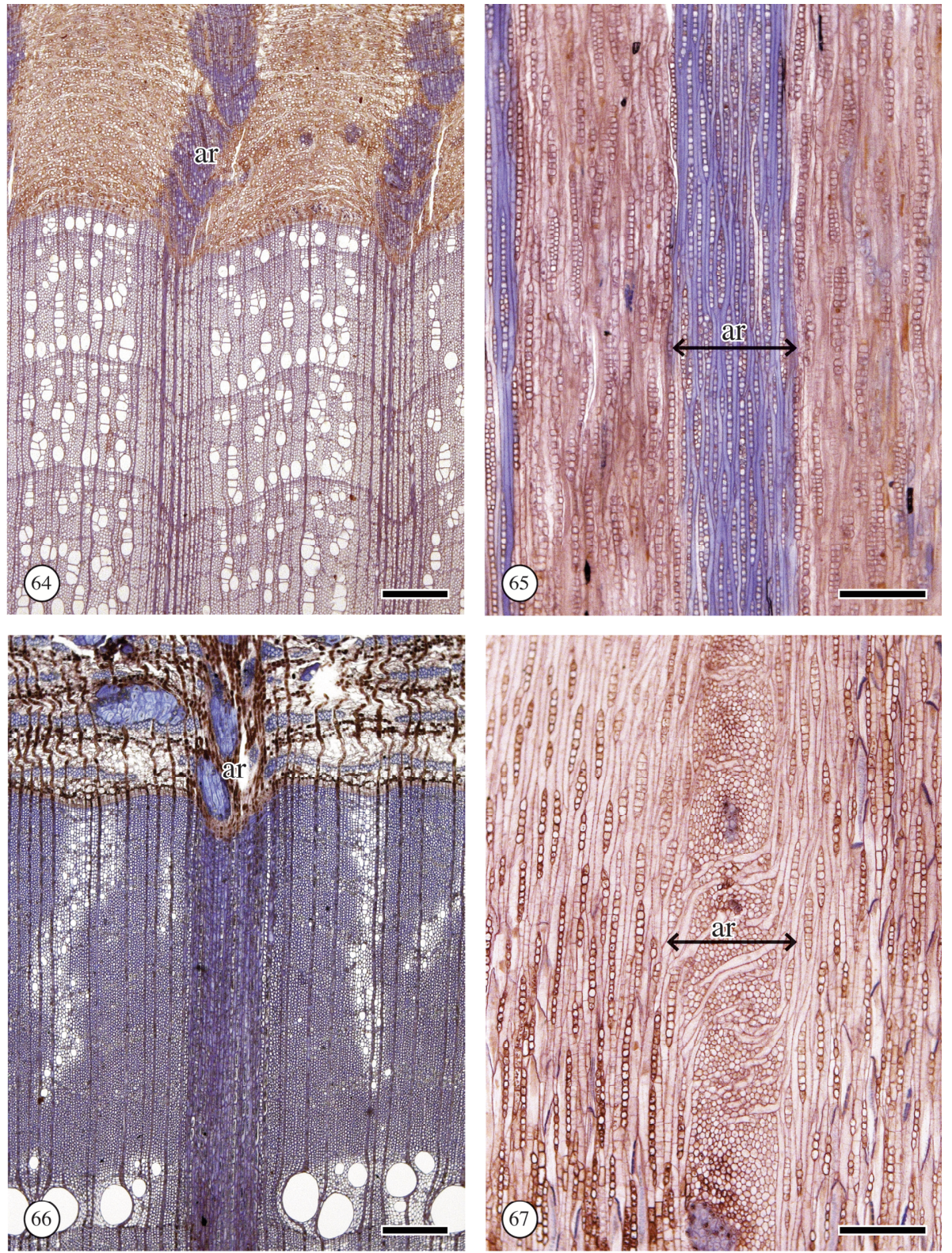

Figure 64-67. - Aggregate rays, rb/fc. - 64 \& 65: Aggregate rays (ar) composed of narrow rays. Carpinus caroliniana (Betulaceae). - 64: Transverse section. - 65: Tangential section. 66 \& 67: Aggregate rays (ar) composed of broad rays. Quercus alba (Fagaceae). - 66: Transverse section. -67 : Tangential section. - Scale bar for $64 \& 66=300 \mu \mathrm{m}$; for $65 \& 67=$ $200 \mu \mathrm{m}$. 

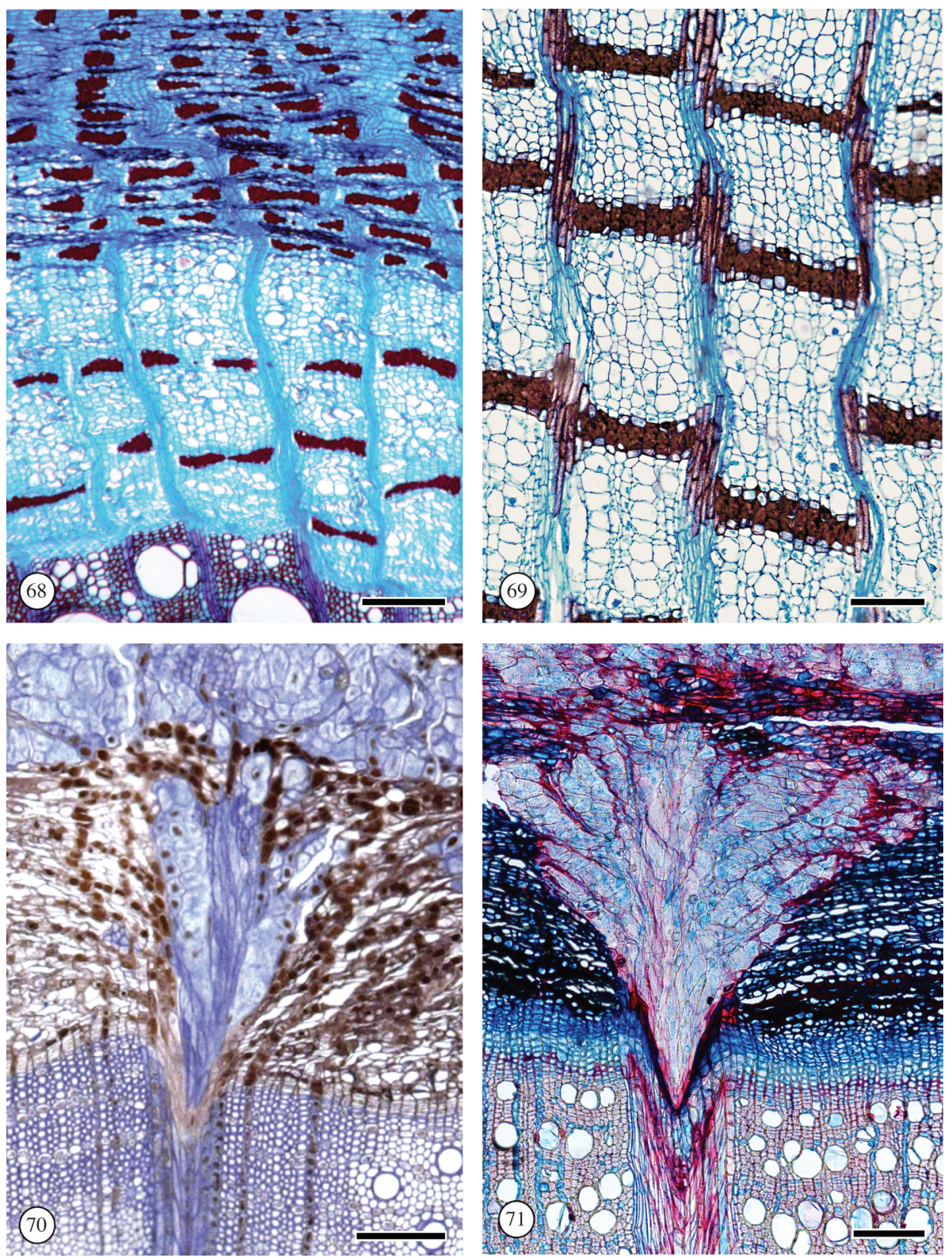

Figure 68-71. - Ray sclerification, transverse sections. - 68: Sclerification of rays absent. Amphilophium crucigerum (Bignoniaceae), ab/s. - 69: Ray cells sclerified when touching sclerenchyma cells. Mansoa difficilis (Bignoniaceae), ab/s. - 70: Central ray cells sclerified (blue). Quercus coccinea (Fagaceae), rb/fc. - 71: Almost all ray cells sclerified. Fagus sylvatica (Fagaceae), ab/s. - Scale bar for $68 \& 70=200 \mu \mathrm{m}$; for $69=100 \mu \mathrm{m}$; for $71=150 \mu \mathrm{m}$. 

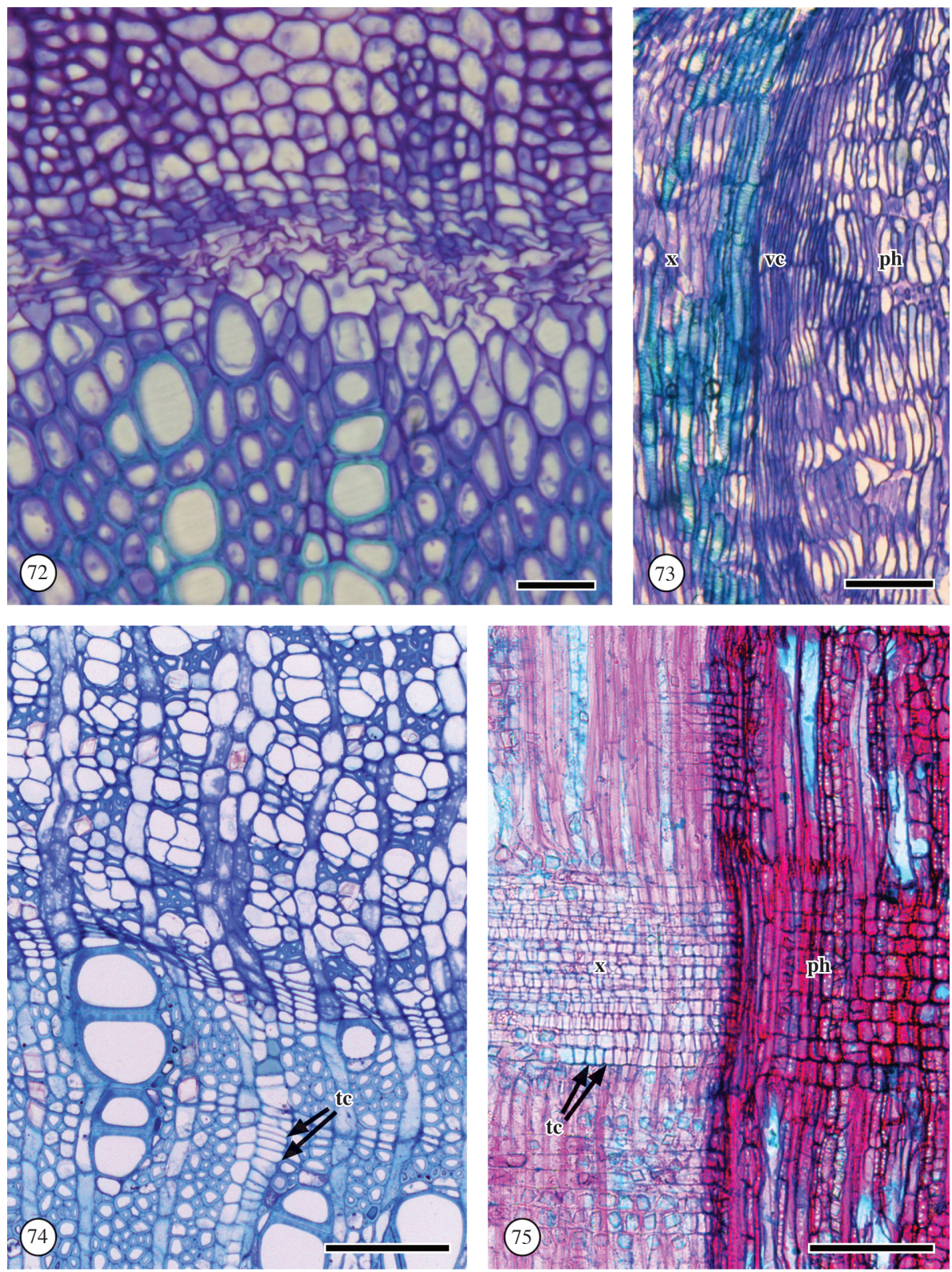

Figure 72-75. - 72 \& 73: Rayless phloem, Arabidopsis thaliana (Brassicaceae) hypocotyl, 1 month old plant, wild type, tb. - 72: Transverse section. - 73: Radial section. - 74 \& 75: Tile cells (tc) present in the xylem and absent in the phloem. Luehea divaricata (Malvaceae). 74: Transverse section, tb. -75 . Radial section, ab/s. $-x=x y l e m, v c=$ vascular cambium, $\mathrm{ph}=$ phloem.- Scale bar for $72=40 \mu \mathrm{m}$; for $73=200 \mu \mathrm{m}$; for $74=100 \mu \mathrm{m}$; for $75=150 \mu \mathrm{m}$. 


\section{Sclerenchyma: Fibers and Sclereids}

\section{Sclerenchyma}

Definition: A tissue composed of sclerified cells that are variable in form and size, and have more or less thick, often lignified, secondary walls. Belongs to the plant's supporting tissues - cells may or may not be devoid of a protoplast at maturity (Evert 2006). Sclerenchyma includes fibers, fiber-sclereids and sclereids.

\section{At the cellular level}

\section{Fibers}

Definition: Elongated, tapering sclerenchyma cells with lignified (or less commonly - in gelatinous fibers - unlignified) secondary walls (Evert 2006).

Comments: Phloem fibers develop either from procambium (primary phloem fibers), or from fusiform cambial derivatives (secondary phloem fibers), typically undergoing intrusive growth during development. Intrusive elongation of fibers can be recognized by tapered tips, and by their longer length in comparison with sieve-tube elements and axial parenchyma strands. Pitting in fiber walls is usually inconspicuous. Some fibers retain their protoplasts at maturity.

Often, fibers in the secondary phloem are accompanied by chambered cristalliferous cells (Kristallkammerfasern, sensu Holdheide 1951) - see under "Mineral inclusions".

Phloem fiber wall thickness can range from thin- to very thick-walled, but in contrast with secondary xylem fibers is of little diagnostic value. Most phloem fibers are thick-walled.

\section{Fiber shape in TS}

65. Rounded to polygonal (fig. 76)

66. Square (fig. 77)

67. Tangentially elongate (fig. 78)

Definition: As per descriptor.

Comments: In most cases fibers are square to rounded or rounded-polygonal in transverse section, but in some plant groups they are characteristically angular and square or rectangular (most conifers and Zamiaceae and Cycas spp.). Because of their tapering ends, the shape in TS of fibers differs between the fiber body and the fiber tips; always determine fiber shape of the fiber body only. Radially elongate sclerenchyma cells may also occur, but then are more likely fiber-sclereids and not fibers (fig. 79). 

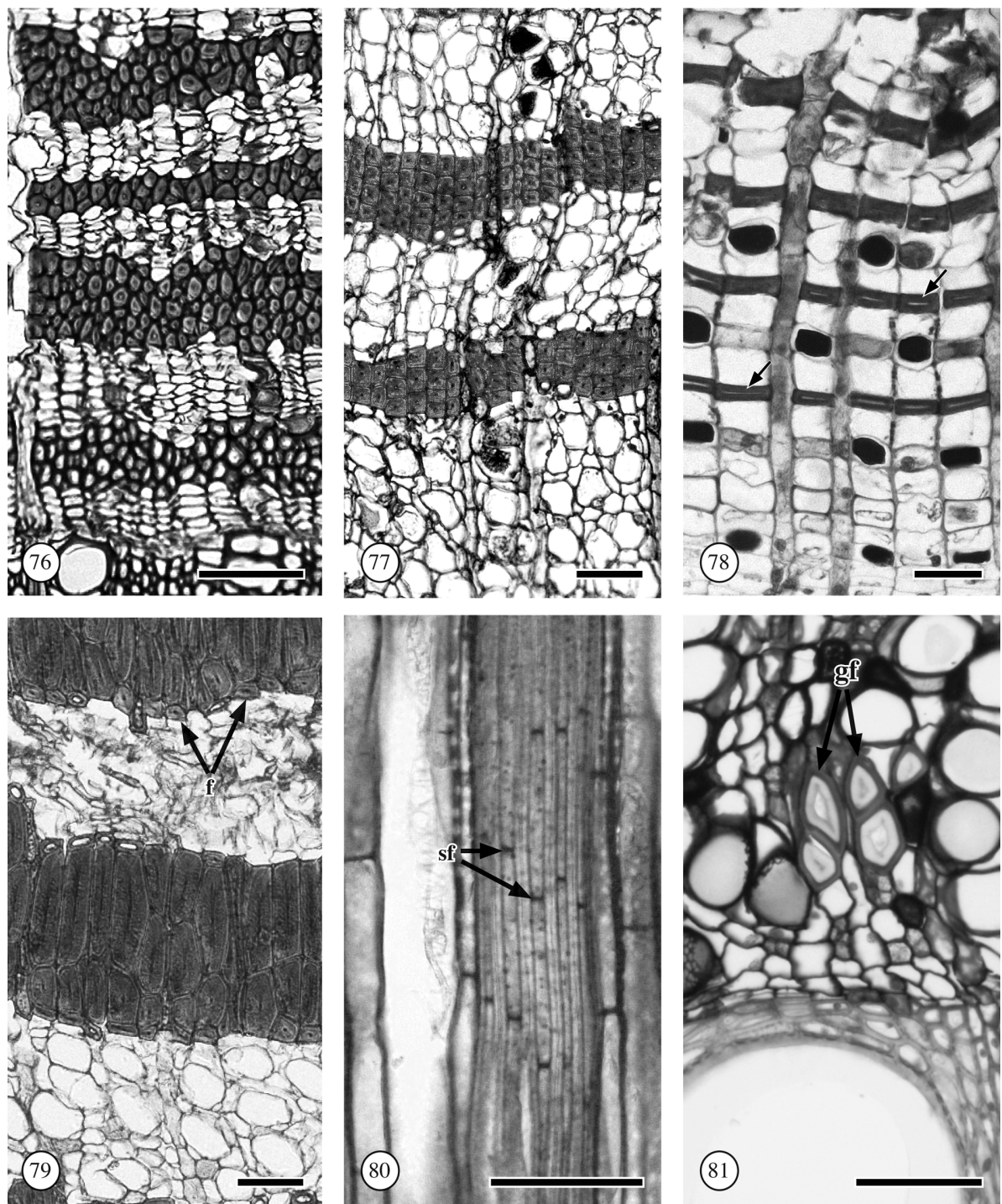

Figure 76-81. - 76-79: Fiber shape, transverse sections. - 76: Fibers rounded to polygonal. Brachylaena transvaalensis (Asteraceae). - 77: Fibers and/or fiber-sclereids square. Anemopaegma chamberlaynii (Bignoniaceae). - 78: Fibers tangentially elongate (arrows). Taxodium distichum (Cupressaceae). - 79: Bands of radially elongate fiber-sclereids, lined by rounded fibers (f). Manaosella cordifolia (Bignoniaceae). - 80: Septate fibers (sf). Vitis riparia (Vitaceae), radial section. - 81: Gelatinous fibers (gf). Stigmaphyllon cavernulosum (Malpighiaceae), transverse section. - Scale bar for $76 \& 81=100 \mu \mathrm{m}$; for $77-80=50 \mu \mathrm{m}$. 


\section{Septate fibers and/or septate fiber-sclereids}

Definition: Fibers or fiber-sclereids with thin division walls formed after completion of the secondary cell wall. Septa are always very thin, unpitted, and do not extend to the compound middle lamella between adjacent fibers or fiber-sclereids (fig. 80).

Comments: Septate fibers and fiber-sclereids are poorly documented for the phloem, and are probably much less common in bark than in wood (Esau 1969; Parameswaran \& Liese 1968, 1970; Roth 1981). Septate fibers were recorded in the barks of Antiaris toxicaria (Moraceae), Cecropia sciadophylla (Urticaceae), Hernandia guianensis (Hernandiaceae), Laetia procera (Salicaceae) and Vitis (Vitaceae).

\section{Gelatinous fibers (fig. 81)}

Definition: Fibers, resembling tension wood fibers in the xylem, with an innermost secondary wall layer, the so-called G-layer, that can be distinguished from the outer secondary wall layer(s) by its high cellulose content and lack of lignin.

Comments: Gelatinous fibers have been recorded in the barks of Antiaris africana (Moraceae), Brya ebenus (Leguminosae), Euphorbia schlechtendalii (Euphorbiaceae), Gouania blanchetiana (Rhamnaceae), Hernandia avigera (Hernandiaceae), Pterocarpus marsupium (Leguminosae), and Stigmaphyllon cavernulosum (Malpighiaceae) (Parameswaran \& Liese 1968, 1970). Their occurrence is probably much more common (Crivellaro \& Schweingruber 2015). Tomlinson (2001, 2003) demonstrated that gelatinous bark fibers in Gnetum (Gnetales) function like reaction wood fibers.

70. Fiber length in $\mu \mathrm{m}$ or $\mathbf{m m}$ (minimum-maximum, mean \pm standard deviation, $\mathrm{n}=\mathrm{x}$ )

Comments: Fiber length in barks may vary strongly with its position in the bark. For instance, primary phloem or pericyclic fibers are often much longer than fibers in the secondary phloem and measure from 5 up to $250 \mathrm{~mm}$ in economically important fiber plants such as Linum (Linaceae), Cannabis (Cannabaceae) and Boehmeria (Urticaceae). Secondary phloem fibers are much shorter than that, but often longer than xylem fibers, although there are also exceptions where the reverse holds true (Esau 1969). Fiber length is an important predictor of the physico-mechanical properties of any fiber product.

Macerations are needed to measure fiber length. For meaningful data, clearly indicate from which part of the bark the fibers were measured, and include at least 25 fibers in each mean value. For analyses of commercial bark fibers a greater number of fibers should be measured. 
71. Sclereids (fig. $82 \& 83$ )

Definition: Sclerenchyma cells, variable in form and size, but typically not much elongated, with thick, often polylamellate, lignified secondary walls with many pits (modified from Evert 2006).

Comments: Sclereids develop mainly in the nonconducting phloem, cortex, and periderm by modification of parenchyma cells. There are some examples of earlier development directly from cambial derivatives, e.g. in Diospyros (Ebenaceae), Styrax (Styracaceae) and Pleonotoma (Bignoniaceae). Sclereids are extremely variable in size and shape. This diversity has been classified into different sclereid types for the plant body as a whole (brachysclereids, columnar sclereids, osteosclereids, astrosclereids, filiform sclereids). The dominant type in bark is the brachysclereid or stone cell (Evert 2006). Pits in sclereids are often conspicuous, but the following informal categories may be used in descriptions and remains to be tested for diagnostic value: inconspicuous; conspicuous with unbranched pit canals; conspicuous with branched pit canals.

\section{Fiber-sclereids (fig. $84 \& 85$ )}

Definition: Elongate sclereids with characteristics intermediate between those of a fiber and a sclereid (Evert 2006).

Comments: Fiber-sclereids originate from axial parenchyma cells in the nonconducting phloem (Holdheide 1951). These cells may or may not undergo some intrusive growth, and at maturity they may be hard to distinguish from true phloem fibers (feature 64). However, in contrast with true phloem fibers their walls are often more distinctly pitted, and polylamellate rather than having the less conspicuous S-wall-layering typical of phloem and xylem fibers, with a dominant $S_{2}$ layer. There are, however, no very precise criteria to separate fibers from fiber-sclereids (Esau 1969). Fiber-sclereids, which typically differentiate later than true phloem fibers, have been recorded $e . g$. in species of Fagus (Fagaceae), Fraxinus (Oleaceae), Malus, Pyrus (Rosaceae), Ulmus (Ulmaceae), and Sambucus (Adoxaceae) (Holdheide 1951; Evert 1960, 1963b; Esau 1969).

\section{At the tissue level}

\section{Sclerification}

73. Absent (fig. 86)

74. Present (fig. 87)

Comments: Sclerification is common in the nonconducting phloem, especially in dilated tissues. In many species massive portions of the secondary phloem sclerify forming large irregular bands or groups of sclerenchyma cells in the nonconducting phloem, in extreme cases the entire ground tissue of the secondary phloem is sclerified (e.g. Diplopterys, Malpighiaceae, Myrsine, Primulaceae, and several Asteraceae). The different character states of bark sclerification are listed below. A minority of woody species have barks that are (virtually) devoid of sclerenchyma, e.g. species of Buxus (Buxaceae), Lycium (Solanaceae), Ribes (Grossulariaceae), Rhus (Anacardiaceae; Esau 1969), and Pinus (Pinaceae; Srivastava 1963). 

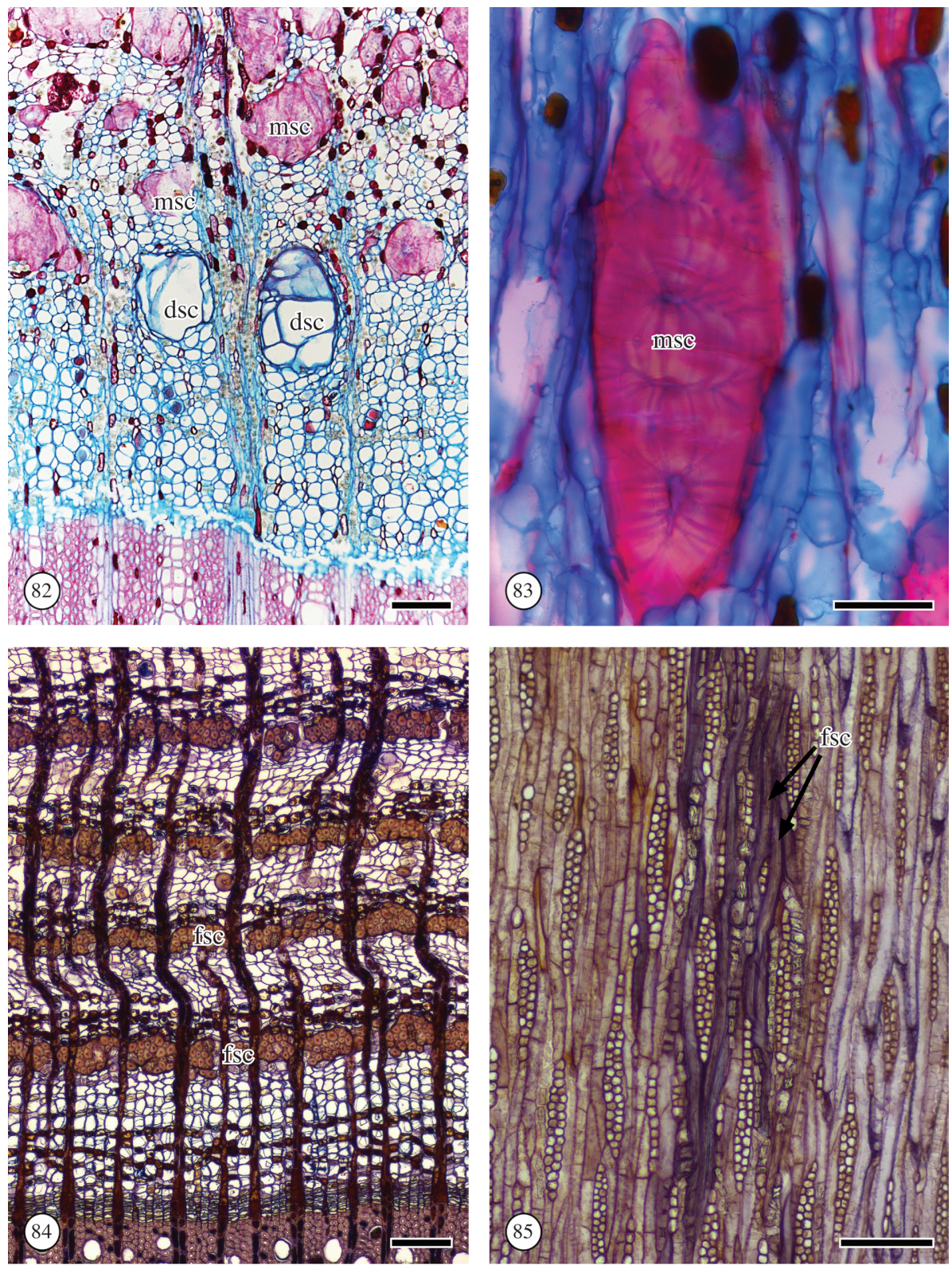

Figure 82-85. - Sclereids. -82 \& 83: Sclereids of Heteropterys intermedia (Malpighiaceae), by courtesy of André C. Lima, ab/s. - 82: Sclereids differentiating from axial parenchyma cells (dsc) and fully differentiated, mature sclereids (msc), transverse section. - 83: Sclereids with conspicuous branched pit canals, radial section. $-84 \& 85$ : Fiber-sclereids (fsc). Malus domestica (Rosaceae), rb/fc. -84 : Transverse section. -85 : Fiber-sclereids (fsc) are elongate, as seen in tangential section. - Scale bar for $82,84 \& 85=100 \mu \mathrm{m}$; for $83=50 \mu \mathrm{m}$. 

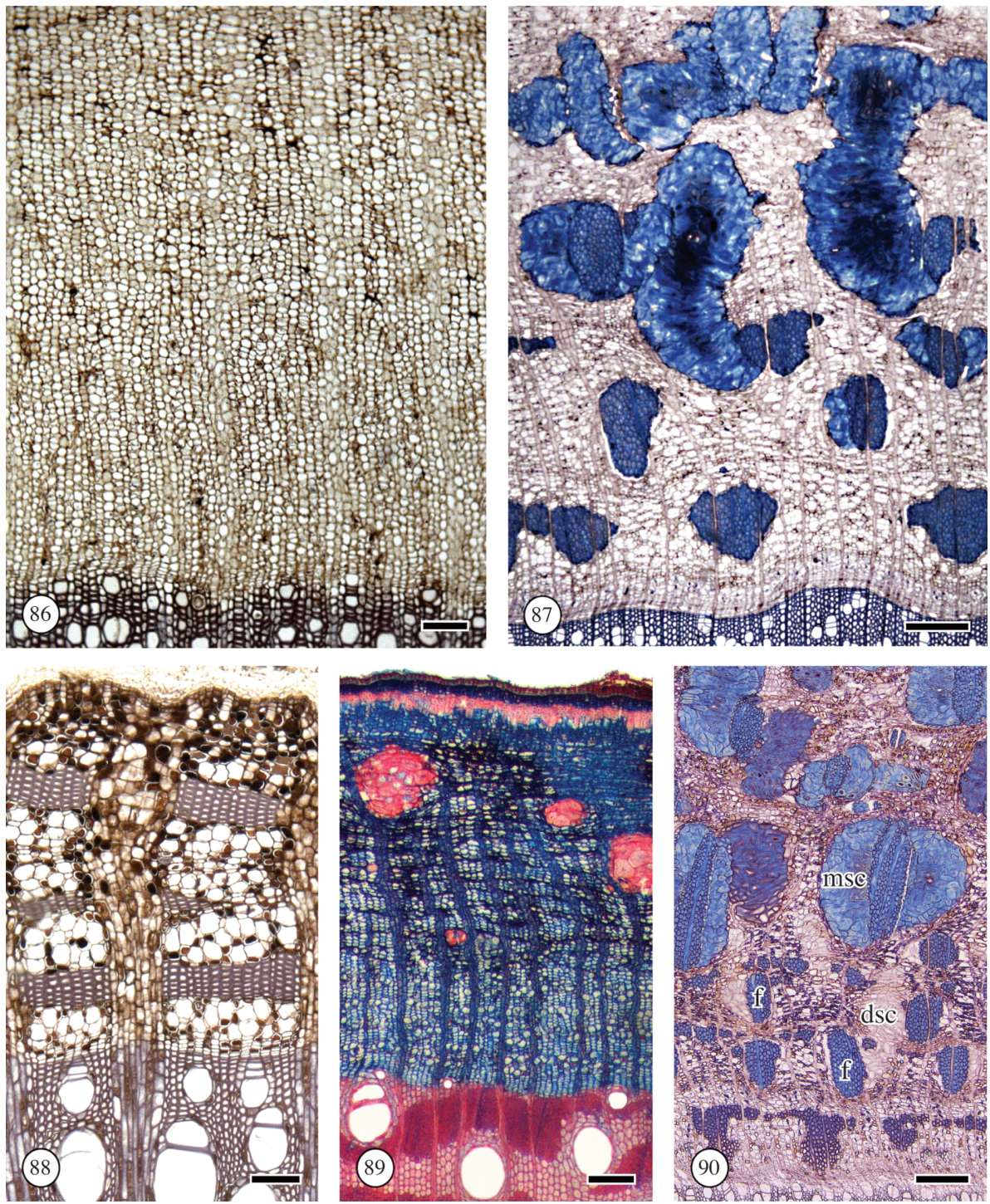

Figure 86-90. - Phloem sclerification, transverse sections. - 86: Phloem devoid of sclerenchyma. Cassinopsis ilicifolia (Icacinaceae), rb/fc. - 87: Sclerification (groups of fibers and sclereid clusters) present. Populus tremuloides (Salicaceae), rb/fc. - 88: Phloem sclerenchyma composed of only fibers. Vitis riparia (Vitaceae), rb/fc. - 89: Phloem sclerenchyma composed only of sclereids. Caesalpinia ferrea (Leguminosae), ab/s. - 90: Phloem sclerenchyma composed of both fibers (f) and mature sclereids (msc) differentiated from cells (dsc) next to the fibers. Populus tremuloides (Salicaceae), rb/fc. - Scale bar for $86 \& 88=100 \mu \mathrm{m}$; for $87=250 \mu \mathrm{m}$; for $89=200 \mu \mathrm{m}$; for $90=150 \mu \mathrm{m}$. 

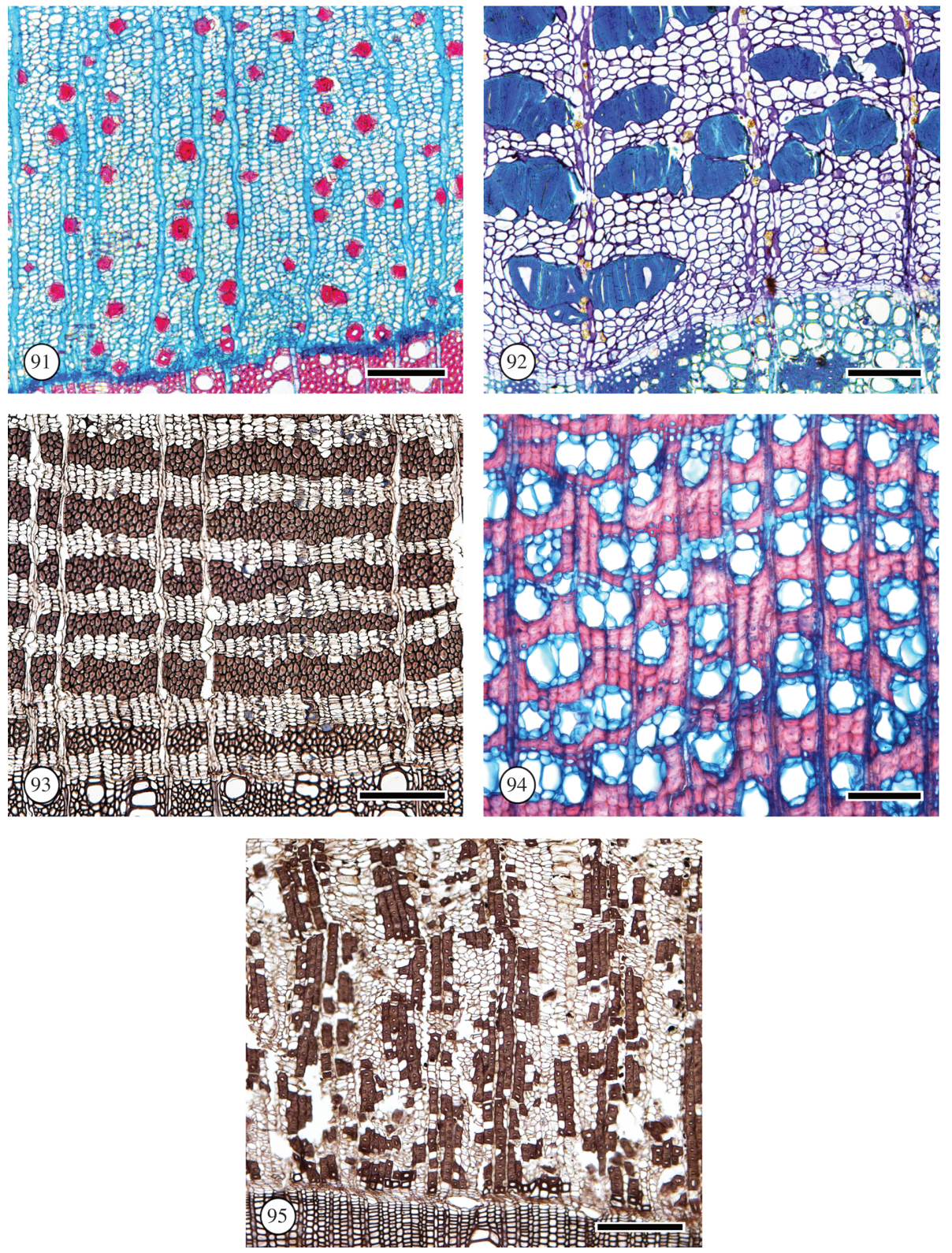

Figure 91-95. - Sclerenchyma arrangement in secondary phloem, transverse sections. 91: Diffuse fibers. Aspidosperma australe (Apocynaceae), ab/s. - 92: Clusters (sclereids). Bunchosia montana (Malpighiaceae), tb. - 93. In tangential bands (fibers). Brachylaena transvaalensis (Asteraceae), rb/fc. - 94: Fibers constituting the ground tissue. Fridericia nigrescens (Bignoniaceae), ab/s. - 95. In radial rows (fibers). Astronidium sp. (Melastomataceae), rb/fc. Scale bar for $91,92 \& 94=150 \mu \mathrm{m}$; for $93 \& 95=200 \mu \mathrm{m}$. 


\section{Composition of sclerenchyma groups}

75. Fibers only (fig. 88)

76. Sclereids only (fig. 89)

77. Fibers and sclereids (including fiber-sclereids) mixed together (fig. 87, 90)

Definition: as per descriptors.

Comments: The composition of sclerenchyma groups (bands, aggregates or clusters) is highly diagnostic. Often they are composed of one cell type only, but combinations of different cell types are common. In several taxa sclerenchyma groups are exclusively composed of fibers in the conducting phloem, and of fibers plus sclereids in the nonconducting phloem (Holdheide 1951; Davis \& Evert 1968; Esau 1969; Pace et al. 2015).

\section{Arrangement of fibers, fiber-sclereids and sclereids}

78. Diffuse and diffuse-in-aggregates: Sclerenchyma cells isolated or in small aggregates scattered among the other cells of the phloem (fig. 91).

79. Clusters: Groups of sclerenchyma cells are nested or clustered together (fig. 92); e.g. Nothofagus (Nothofagaceae) and several Malpighiaceae.

80. Tangential bands: Sclerenchyma cells present in continuous or discontinuous tangential bands, alternating with other cells of the secondary phloem (fig. 93). This arrangement is most common for phloem fibers (e.g. in Malvales s.l.), but tangential bands may also incorporate sclereids or fiber-sclereids.

81. Fibers constituting ground tissue of the secondary phloem (fig. 94): e.g. several Bignonieae with sieve-tube-centric parenchyma (Pace et al.2015) and some species of Polygalaceae and Carya (Juglandaceae; Evert 2006).

82. Radial rows: Sclerenchyma cells in radial rows (fig. 95) (e.g. Coincya, Brassicaceae and Jatropha dhofarica, Euphorbiaceae).

\section{Fiber or fiber-sclereid band width}

83. Narrow: 1(-2) cells wide (fig. 96)

84. Medium: (2-)3-5 cells wide (fig. 97)

85. Wide: more than 5 cells wide (fig. 98)

Definition: as per descriptors.

Comments: The width of the fiber bands can be diagnostic, e.g. in several Lauraceae (Richter 1981), and lianescent Bignoniaceae (Pace et al.2015), sometimes at the genus level but more often at species level. However, there is also considerable variation within some species, sometimes related to seasonality. 

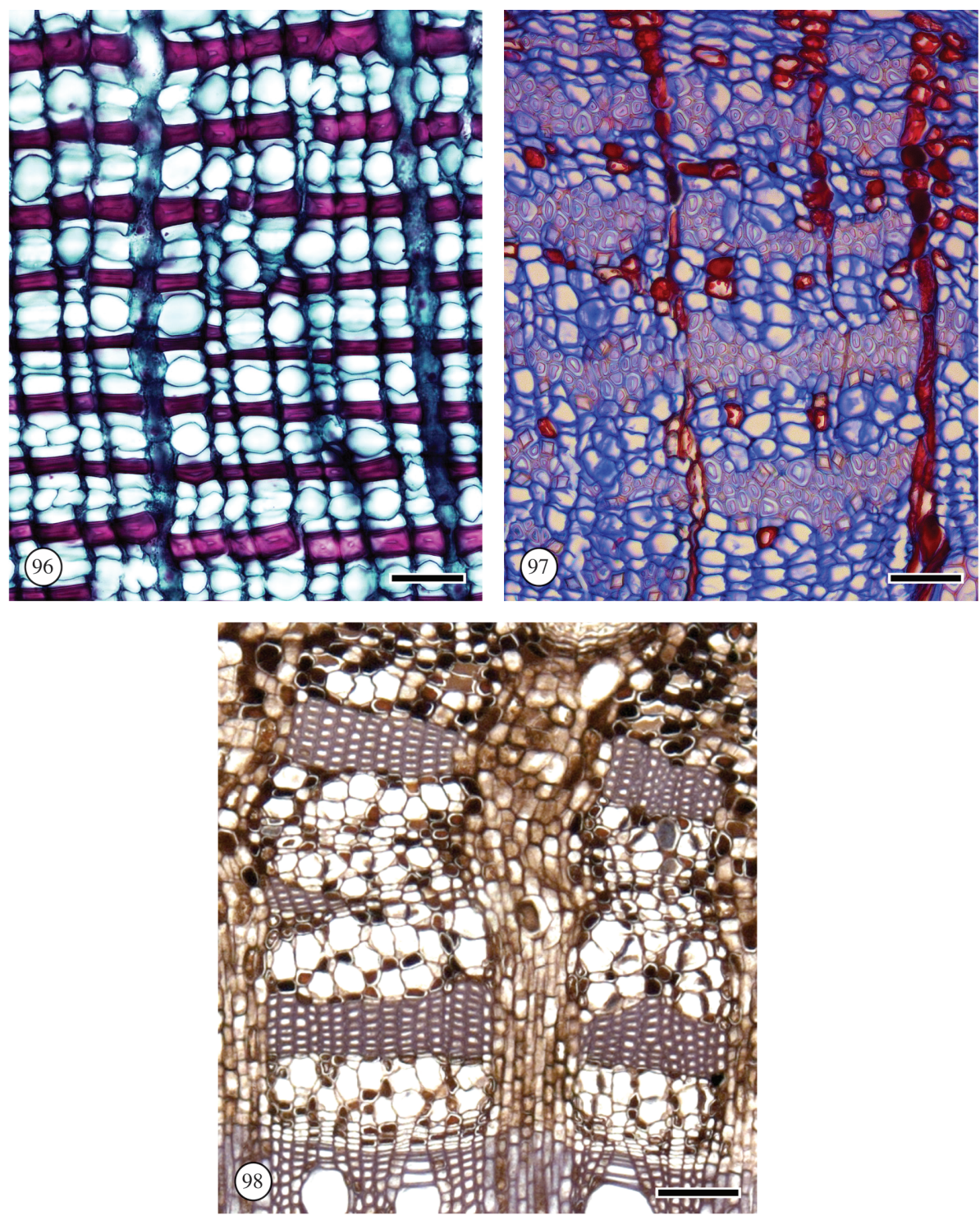

Figure 96-98. - Fiber band width, transverse sections. - 96: Narrow fiber bands. Juniperus flaccida (Cupressaceae), fg/s. - 97: Medium width fiber bands. Mimosa velloziana (Leguminosae). Note that these fibers are gelatinous, ab/s. -98 : Wide fiber bands. Vitis riparia (Vitaceae), rb/fc. - Scale bar for $96 \& 97=50 \mu \mathrm{m}$; for $98=100 \mu \mathrm{m}$. 

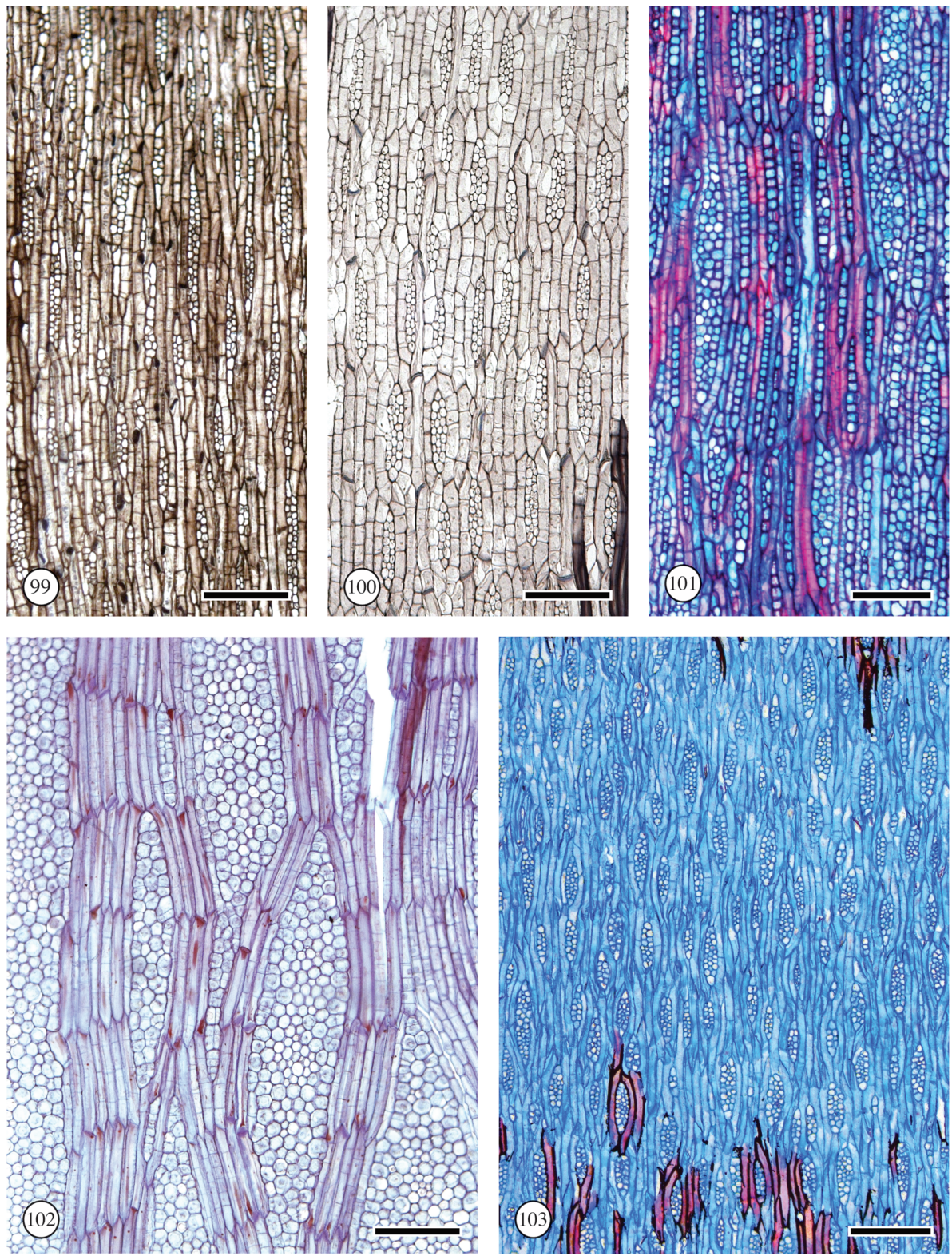

Figure 99-103. - Storied structure, tangential sections. - 99: Phloem elements nonstoried. Sideroxylon (Sapotaceae), rb/fc. - 100: All rays storied. Note also storied axial parenchyma and sieve-tube elements. Brachylaena transvaalensis (Asteraceae), rb/fc. - 101: Low rays storied, high rays nonstoried. Luehea divaricata (Malvaceae), ab/s. - 102: Axial parenchyma and sievetube elements storied, rays nonstoried. Brachychiton (Malvaceae), rb/fc. - 103: Rays and axial elements irregularly storied. Moquiniastrum polymorphum (Asteraceae), ab/s. - Scale bar for $99 \& 100=200 \mu \mathrm{m}$; for $101 \& 103=150 \mu \mathrm{m}$; for $102=100 \mu \mathrm{m}$. 


\section{Storied structure}

\section{Storied structure}

Definition: Axial and/or radial elements arranged in horizontal tiers on tangential surfaces (to be analyzed in the conducting phloem in TLS).

86. Phloem elements nonstoried (fig. 99)

87. All rays, axial parenchyma and sieve-tube elements storied (fig. 100)

88. Low rays storied, high rays nonstoried (fig. 101)

89. Axial parenchyma and/or sieve elements storied (fig. 102)

90. Rays and/or axial elements irregularly storied (fig 103)

Comments: In most angiosperms and all conifers the cambium and secondary phloem and xylem are not storied. In some eudicots storied structure occurs (see also IAWA Committee1989 for definitions and examples in the xylem). There should be a one to one relationship between storied structure in secondary xylem and the conducting phloem, but dilatation phenomena may disturb storeying in the nonconducting phloem in older barks.

\section{Phloem growth rings}

Definition: A growth layer of secondary phloem produced during a single growth season (usually annual; fig. 104-107).

Comments: The identification of growth rings, or growth increments, must be made with reference to accurately dated development of the tissues throughout the seasons. Abrupt change in radial diameter from early to late sieve elements in the same year appears to be the best documented growth ring marker in conifers (Srivastava 1963; Alfieri \& Evert 1968, 1973; Alfieri \& Kemp 1983) and woody angiosperms from both temperate (Huber 1939; Derr \& Evert 1967; Tucker \& Evert 1969) and tropical environments (Deshpande \& Rajendrababu 1985; Rajput \& Rao 1998; Amano et al.2003; Angyalossy et al. 2007). Radially narrow sieve elements (fig. 107) can be terminal markers (Artschwager 1950; Rajput \& Rao 1998; Amano et al.2003; Angyalossy et al . 2007). Tangential bands of certain cell types (of fibers, fiber-sclereids, parenchyma) are usually not growth ring markers, as for instance in Tilia americana (Malvaceae) which forms more than one fiber band per year, although the first-formed band of phloem fibers in a given increment is often wider than the last-formed band (fig. 105). In some species a band of axial parenchyma is a terminal marker (Jenke 1971; fig. 106).

\section{Primary phloem}

Definition: Phloem differentiated from the procambium in the primary plant body, and spatially associated with the primary xylem in the vascular system.

Comments: Primary phloem is composed of sieve elements, companion cells, parenchyma cells, and often also fibers that develop in the nonconducting protophloem. In mature barks remnants of the primary phloem (except the fibers) are usually collapsed and obliterated by dilatation phenomena. 

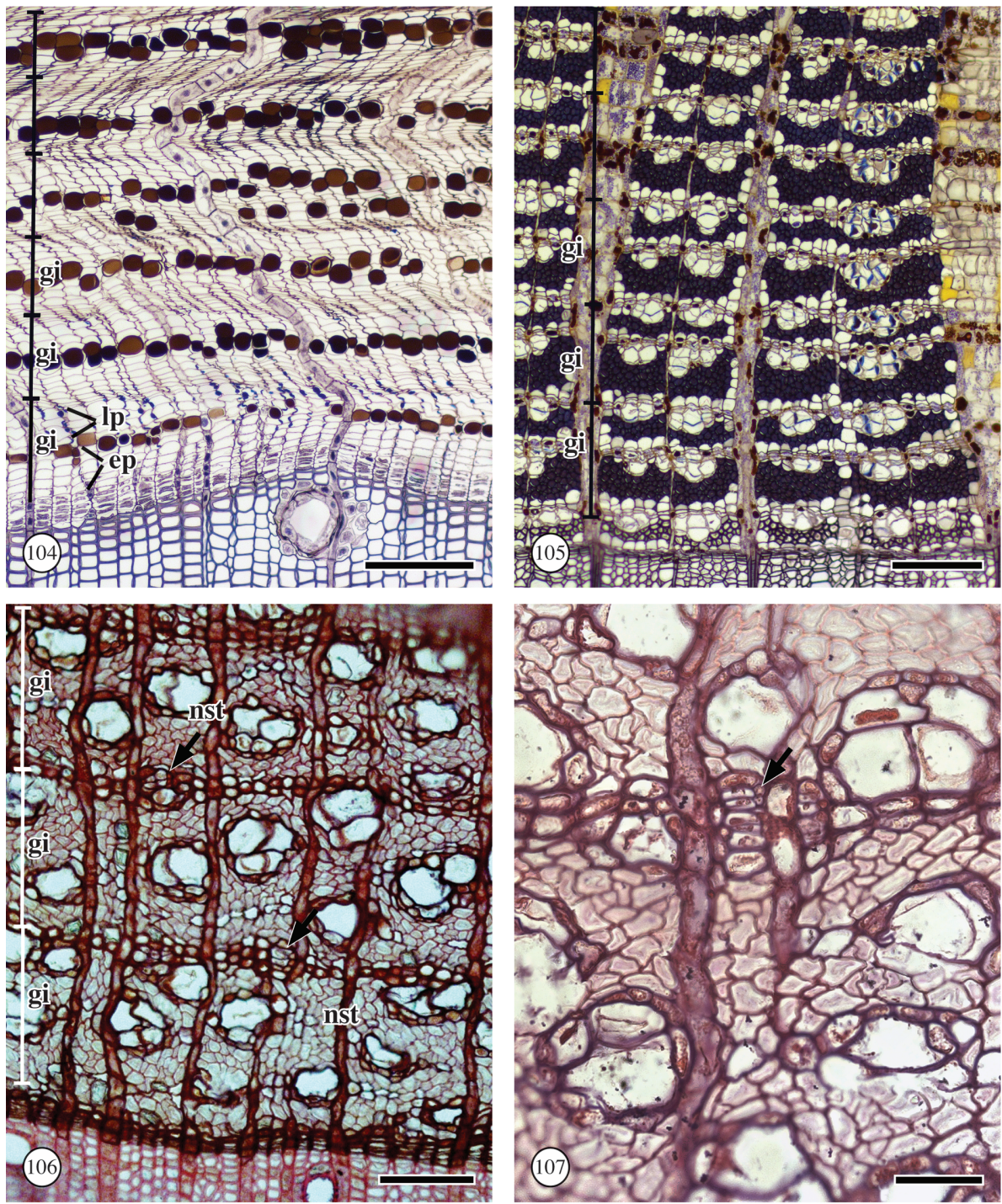

Figure 104-107. Growth rings, transverse sections. - 104: Grown increments (gi, brackets) can be delimited by presence of collapsed late phloem sieve cells at the end of each growth increment. A continuous band of phloem parenchyma separates early phloem (ep) from late phloem (lp). Pinus strobus (Pinaceae), by courtesy of Frank J. Alfieri. - 105: Growth increments (gi, brackets) can be delimited by the alternation of thick and narrow fiber bands. Tilia americana (Malvaceae).- 106 \& 107. Carya cordiformis (Juglandaceae). - 106: Growth rings delimited by radially narrow sieve-tubes (nst) arranged in radial rows, embedded in a band of terminal axial parenchyma. -107 : Detail of the radially narrow sieve tubes arranged in a radial row (arrow). Scale bar for $104 \& 105=200 \mu \mathrm{m}$; for $106=100 \mu \mathrm{m}$; for $107=40 \mu \mathrm{m}$. 


\section{Pericyclic and protophloem fibers and sclereids (fig. 108-110)}

Definition: Pericyclic fibers are located in the periphery of the vascular cylinder inside the innermost cortical layer (endodermis or starch sheath) and outside the primary phloem. Protophloem fibers (also called primary phloem fibers) originate in the earliest part of the primary phloem (the protophloem) but mature as fibers after this part of the phloem ceases to function in conduction.

Comments: Since a developmental study is required to distinguish between pericyclic fibers and protophloem fibers, systematic anatomists long have referred to both groups of fibers as pericyclic fibers (Metcalfe \& Chalk 1950; Blyth 1958; Metcalfe \& Chalk 1979). Esau (1979) suggested that the simple topographical designation "pericycle" or "pericyclic" may continue to be used, rather than introducing a special term such as perivascular for this purpose.

The various distribution patterns as seen in transverse sections are:

\section{Pericycle remaining parenchymatous}

92. Pericycle with a ring of discrete fiber strands embedded in parenchymatous ground tissue (fig. 108)

93. Pericycle with a continuous or nearly continuous closed ring of fibers (fig. 109)

94. Pericycle with alternating groups of fibers and sclereids in a continuous or nearly continuous ring (fig. 110)

Definitions: As per descriptors.

Comments: The pattern of pericyclic sclerenchyma varies with the age of the material, so that for taxonomic or diagnostic purposes equivalent stages of development must be compared. With increasing stem diameter, continuous fiber rings may become disrupted. In some species, parenchyma cells intrude into the gaps and may develop into sclereids. In barks with subsequent periderms, the pericyclic sclerenchyma may be shed.

\section{Cortex}

\section{Cortex}

Definition: Primary ground tissue region between the vascular system and the dermal tissue (epidermis/superficial periderm) (fig. 108-110).

Comments: In the bark the cortex usually is highly modified due to dilatation (see page 544). In this bark list we only mention the most important characters that may be retained for a long time in the cortex.

The ground tissue is usually composed of parenchyma and collenchyma, with or without extensive intercellular spaces. Chloroplasts are often present. This ground tissue can become highly sclerified in diverse patterns. Secretory structures and cells containing crystals can also be present. In certain families, cortical vascular bundles occur (e.g. Araliaceae, Cactaceae, Melastomataceae, Piperaceae, Napoleonaea of the Lecythidaceae s.l.). 

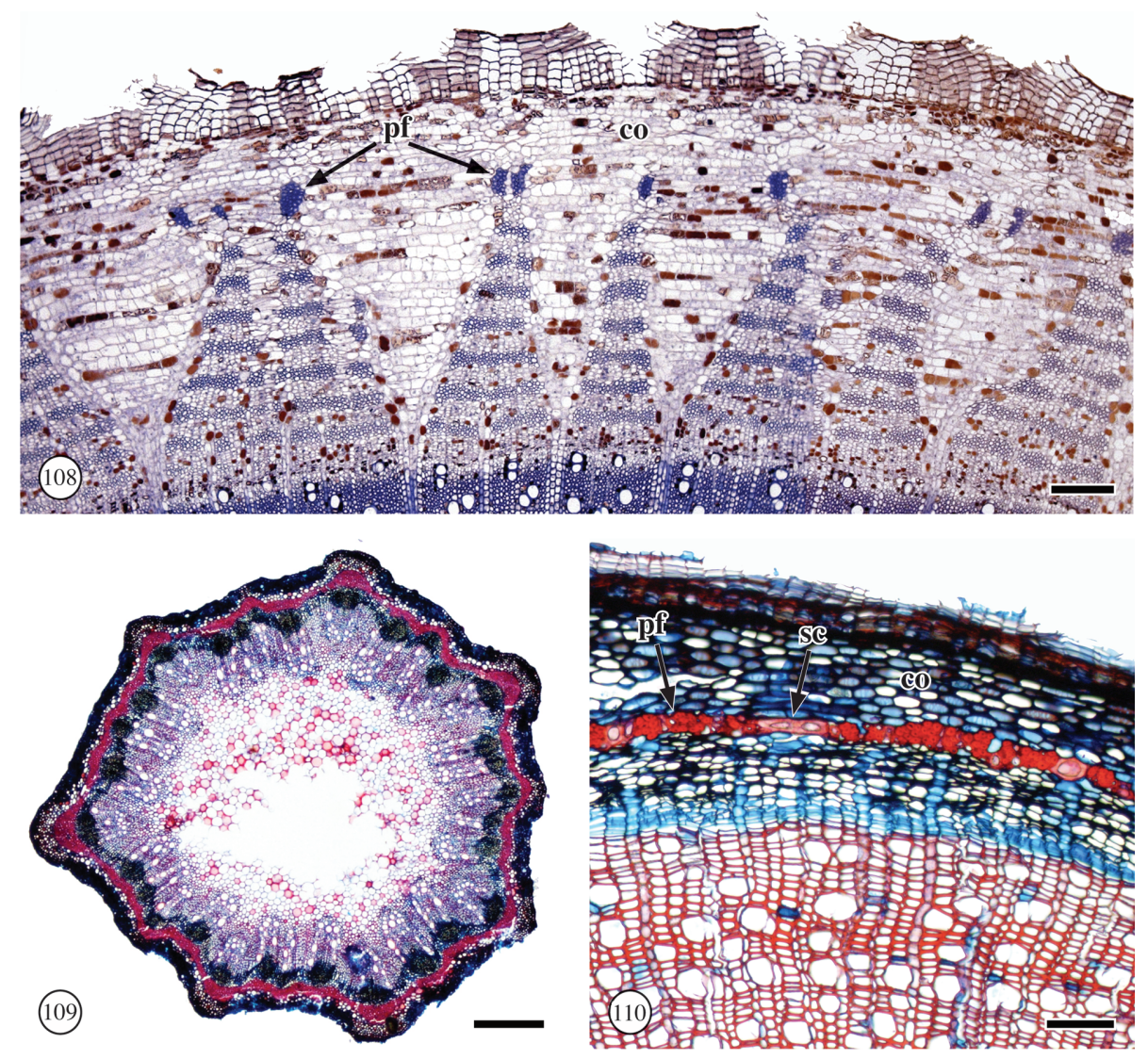

Figure 108-110. - Pericyclic fibers (pf). - 108: Pericycle with a ring of discrete fiber strands embedded in parenchymatous tissue, Gossypium anomalum (Malvaceae), rb/fc. - 109: Continuous or nearly continuous pericyclic fibers. Plumbago europaea (Plumbaginaceae), ab/s. 110: Alternating groups of pericyclic fibers (pf) and sclereids (sc). Alnus orientalis (Betulaceae), ab/s. - co $=$ cortex. - Scale bar for $108 \& 110=100 \mu \mathrm{m}$; for $109=1 \mathrm{~mm}$.

\section{Variation in the location of the phloem}

General comment: Although not strictly forming part of the bark (defined as all tissues outside the vascular cambium), we give here a brief overview of alternative phloem locations in the primary and secondary plant body.

\section{Intraxylary phloem}

Definition: Phloem strands present at the periphery of the pith (also called internal phloem, fig. 111).

Comments: In the primary plant bodies of some families (notably the Cucurbitaceae) the primary vascular bundles contain both internal and external phloem derived from the same procambial strand (Hérail 1885; Fukuda 1967). Such bundles are called bicollateral bundles. In other plants some of the internal phloem of stems form independent strands 
in the peripheral part of the pith, separated from the protoxylem by a few parenchyma cells. The term intraxylary phloem is used to denote phloem strands in the periphery of the pith (Fukuda 1967; Metcalfe 1983a). Entire orders (e.g. Myrtales) and families (e.g. Apocynaceae, Convolvulaceae) have intraxylary phloem as a constant feature of great diagnostic value.

\section{Cambial variants}

In some plants the form of secondary growth and hence the location of the secondary phloem deviates considerably from the common form in which a single vascular cambium produces secondary phloem externally and secondary xylem internally. The term cambial variant is used to indicate such deviant secondary growth. Cambial variants are more common in lianas than in any other life form (Schenck 1893; Chodat \& Vischer 1917; Carlquist 2001; Angyalossy et al. 2015). Three types of cambial variants are considered here: successive cambia, interxylary phloem produced by a single cambium, and phloem wedges (furrowed xylem).

\section{Phloem strands or bands produced by successive cambia present throughout the stem (fig. 112)}

Definition: As per descriptor.

Comments: Series of vascular cambia arise successively outside the original cylinder of vascular bundles and produce secondary xylem towards the inside and secondary phloem towards the outside. The strands of xylem and phloem are usually embedded in parenchyma and/or sclerenchyma tissue called "conjunctive tissue" (fig. 112).

In the past the phloem produced by successive cambia has been incorrectly referred to as interxylary phloem and included phloem (also in the IAWA Committee 1989). Carlquist (2007) notes that the secondary phloem of successive cambia is not included within the wood and recommends that the term included phloem be abandoned. We concur with his recommendation. Carlquist (2001) lists 34 families of eudicotyledons, some genera of which have successive cambia.

\section{Interxylary phloem produced by a single cambium present throughout the stem (fig. 113-115)}

Definition: Strands of phloem embedded in the secondary xylem.

Comments: The presence of a single vascular cambium is emphasized by Carlquist $(2001,2013)$ to distinguish interxylary phloem from the phloem produced by successive cambia. Interxylary phloem may be produced in three different ways (Bonnemain 1969; Van Veenendaal \& Den Outer 1993): (1) by small segments of the vascular cambium producing phloem strands toward the inside for a brief period instead of xylem (fig. 113); (2) by small segments of the vascular cambium that temporarily produce little or no xylem, resulting in depressions in which increased outward phloem production results in phloem strands that are later overarched by flanking cambium producing inward xylem and outward phloem at normal rates (fig. 114). (3) In this mode of interxylary phloem formation, certain axial parenchyma cells some distance from the vascular cambium dedifferentiate and redifferentiate as strands of phloem (fig. 115). Carlquist (2013) lists 15 families of eudicotyledons for which the presence of interxylary phloem has been "well substantiated". 
98. Phloem wedges. Certain portions of the cambium reduce the production of xylem and increase the production of phloem, forming phloem wedges that furrow the xylem (fig. 116), e.g. Bignoniaceae, Icacinaceae.
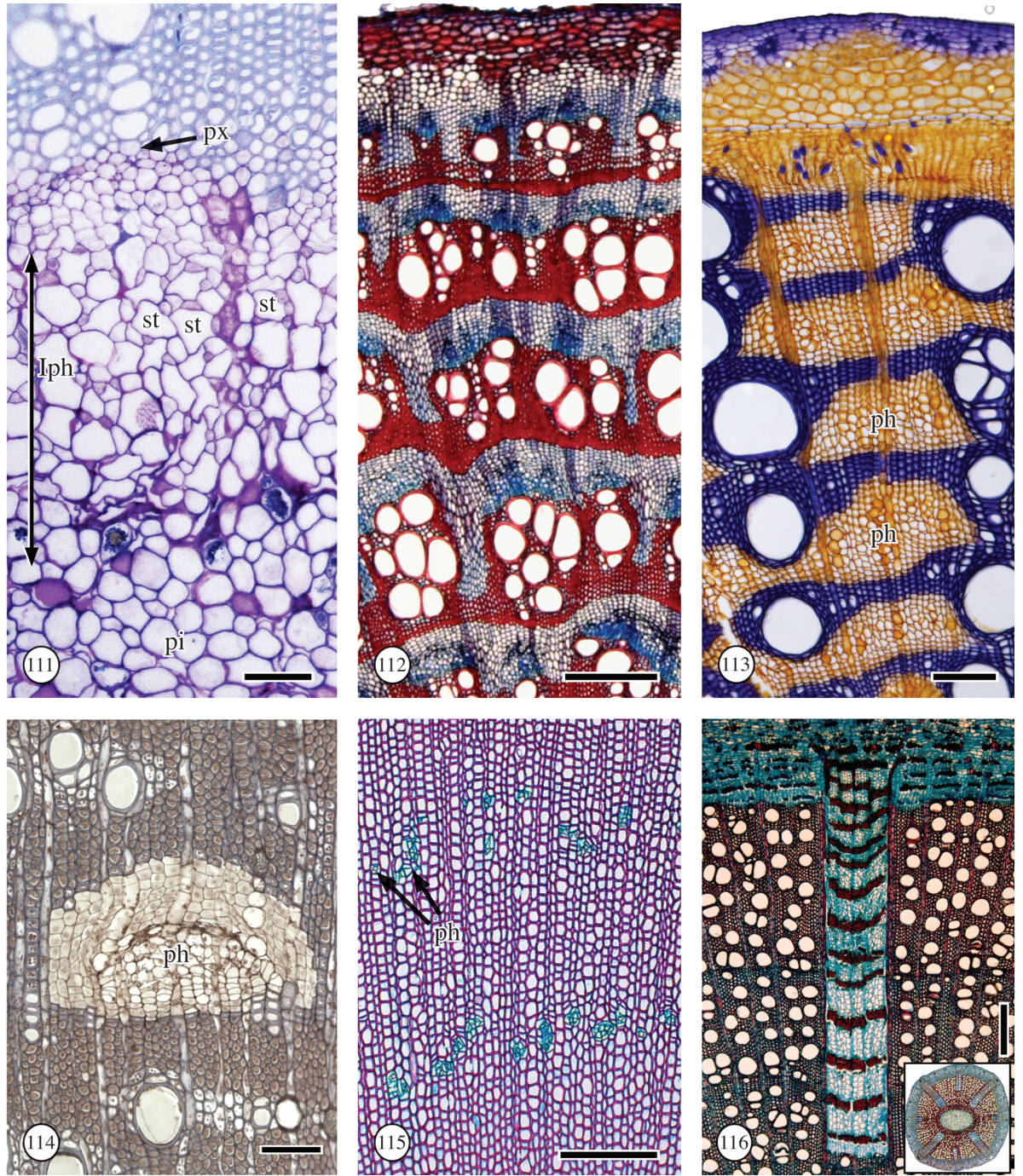

Figure 111-116. - Variation in the location of the phloem, transverse sections. - 111: Intraxylary phloem. Odontadenia lutea (Apocynaceae), tb. - 112: Phloem produced by successive cambia. Hebanthe eriantha (Amaranthaceae), ab/s. - 113-115: Interxylary phloem. 113: Thunbergia alata (Acanthaceae), og/cv. - 114: Combretum apiculatum (Combretaceae), $\mathrm{rb} / \mathrm{fc}$. - 115: Ixanthus viscosus (Gentianaceae), ab/s. - 116: Phloem wedge in detail. Note in the lower right part how the phloem wedges are distributed in the stem. Bignonia magnifica $($ Bignoniaceae $), a b / s .-I p h=$ intraxylary phloem, $\mathrm{ph}=$ phloem, $\mathrm{pi}=$ pith, $\mathrm{px}=$ protoxylem, st $=$ sieve-tube. - Scale bar for $111=50 \mu \mathrm{m}$; for $112=400 \mu \mathrm{m}$; for $113=200 \mu \mathrm{m}$; for $114 \&$ $116=500 \mu \mathrm{m}$; for $115=100 \mu \mathrm{m}$. 


\section{Periderm and Rhytidome (outer bark)}

\section{Periderm}

Definition: Secondary protective tissue that replaces the epidermis in stems and roots, rarely in other organs. Consists of phellem (cork), phellogen (cork cambium), and phelloderm (Evert 2006) (fig. 117).

\section{Phellogen (or cork cambium)}

Definition: A lateral meristem forming the periderm. Produces phellem (cork) to the outside, and phelloderm to the inside by periclinal cell divisions (Evert 2006) (fig. $119,132)$.
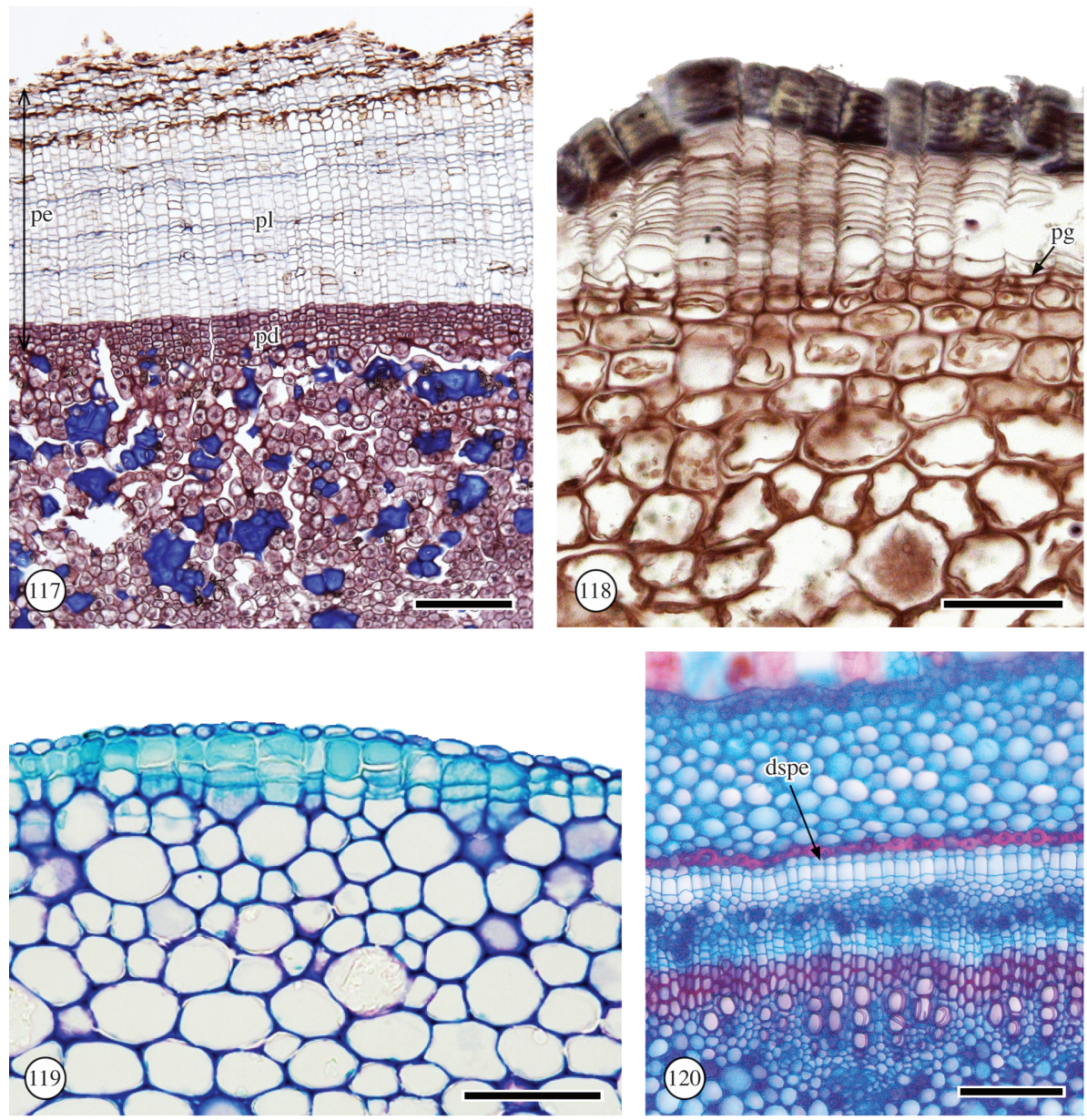

Figure 117-120. - 117 \& 118: Periderm, transverse sections. - 117: Periderm (pe), phellem (pl) and phelloderm (pd). Phellodendron amurense (Rutaceae), rb/fc. - 118: Phellogen (pg). Pereskia (Cactaceae), rb/fc. - 119. Periderm origin subepidermal. Miconia chamissois (Melastomataceae), tb. -120 . Periderm origin deep seated (dspe). Tibouchina heteromalla (Melastomataceae), $\mathrm{ab} / \mathrm{s}$. - Scale bar for $117=200 \mu \mathrm{m}$; for $118=100 \mu \mathrm{m}$; for $119=50 \mu \mathrm{m}$; for $120=150 \mu \mathrm{m}$. 


\section{Origin of the first periderm (= location of the first phellogen)}

The location of the first phellogen is often diagnostic and can be phylogenetically informative. Metcalfe \& Chalk (1950) listed families with so-called superficial and deep-seated cork, referring to respectively epidermal, subepidermal and outer cortex layers, or inner cortex, endodermis and/or pericycle as site of origin for the first periderm. Later formed, subsequent, or sequent, periderms originate more deep-seated, usually in the nonconducting phloem, but sometimes even in the phelloderm of the earlier periderm (Evert 2006).

\section{Epidermal}

100. Subepidermal layer (fig. 119)

101. Second and third cortical layers

102. Deep-seated: in inner cortex, endodermis, pericycle or the phloem (fig. 120)

Comments: the first-formed periderm originates relatively rarely in the epidermis itself. Evert (2006) mentions Malus, Pyrus (Rosaceae), Nerium (Apocynaceae), Myrsine (Primulaceae) and Viburnum (Adoxaceae). Cactaceae constitute another example (Terrazas \& Arias 2003). The subepidermal cortex layer is the most common site of origin of the first periderm. Aristolochia (Aristolochiaceae), Quercus (Fagaceae), Gleditsia, Robinia (Leguminosae), Pinus and Larix (Pinaceae) are examples with periderms originating in the outer (second and third) cortical cell layers. These cell layers as well as the subepidermal layer may be collenchymatous, before dedifferentiating into thin-walled meristematic phellogen cells. Deep-seated periderms occur in stems of for instance Amaranthaceae s.l., Caryophyllaceae, Cupressaceae and Ericaceae. A pericyclic origin of the periderm is typical of roots of both conifers and angiosperms (Eames \& MacDaniels 1947; Esau 1969; Fahn 1974; Evert 2006).

\section{Rhytidome}

Definition: The outer bark, which consists of the innermost periderm and tissues isolated by it, namely more peripheral periderms, phloem tissues, and - until shed - cortical tissues and epidermis (fig. 1 \& 2).

Comments: Rhytidome formation occurs by the successive development of periderms. Consequently, barks that have only one superficial periderm by definition do not form a rhytidome (Roth 1981; Evert 2006).

\section{Arrangement of sequent periderms (as seen in TS)}

\section{Reticulate (net-like)}

Definiton: Sequent periderms appear as discontinuous but overlapping and anastomosing layers, resulting in a net-like appearance (fig. 121).

Comment: A reticulate pattern of sequent periderms is very common, and is associated with scaly bark (as in Tilia, Malvaceae; fig. 2), where individual scales correspond with approximately shell-shaped rhytidome fragments which are delimited by reticulate subsequent periderms. 

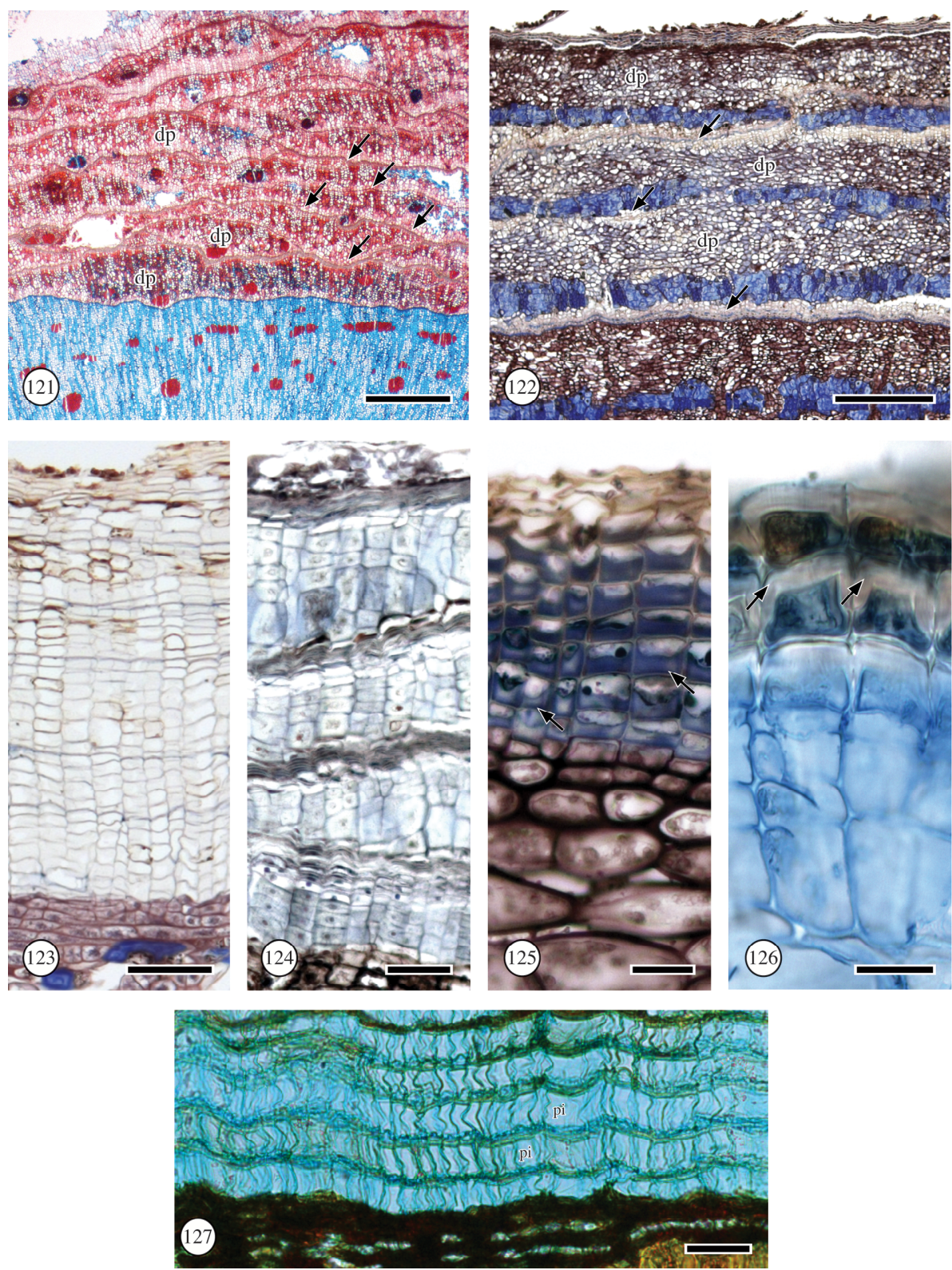

Figure 121-127. - $121 \&$ 122: Appearance of sequent periderms, transverse sections (arrows $=$ periderms, $\mathrm{dp}=$ dead phloem).-121 : Reticulate (net-like). Podranea ricasoliana (Bignoniaceae), ab/s. - 122: Concentric. Nyssa sylvatica (Cornaceae), rb/fc. $-123 \& 124$. Types of phellem cells. - 123: Phellem cells evenly thin-walled. Phellodendron amurense (Rutaceae), radial section, rb/fc. - 124: Phellem cells evenly thick-walled. Capparis tomentosa (Capparaceae), transverse section, rb/fc. - 125: Phellem cells with U-shaped thickenings (arrows). Berberis pruinosa (Berberidaceae), transverse section, $\mathrm{rb} / \mathrm{fc}$. -126 : Phellem cells with inversely 


\section{Concentric}

Definition: Sequent periderms arranged in (nearly) continuous concentric layers (fig. 122).

Comments: Concentric periderms are less common than reticulate periderms and are associated with ring bark as occurs in for instance several Cupressaceae, Clematis (Ranunculaceae), Lonicera (Caprifoliaceae), Vitis (Vitaceae; Evert 2006). In some barks the sequent periderms run concentric for a relatively long distance before they anastomose, resulting in an intermediate character state, associated with very large scales, typical of Platanus (Platanaceae) barks.

\section{Phellem (cork)}

Definition: Protective tissue composed of nonliving cells with suberized walls and formed centrifugally by the phellogen (cork cambium) as part of the periderm (Evert 2006) (fig. 123-126).

Comments: Phellem cells are usually compactly arranged in radial files, and nonliving at maturity. They are mostly air-filled. Cork is a technical term for the phellem. Phellem or cork can greatly vary in thickness between and within species. It may show clear seasonal growth increments marked by abrupt changes in the radial diameter of the phellem cells, for instance in Quercus suber (Fagaceae), the cork oak, Betula papyrifera (Betulaceae), and Rhus typhina (Anacardiaceae). Other types of layering of the phellem may also occur (see below).

\section{Types of phellem cells}

Comment: Although often a uniform tissue of compact, suberized walls, the mature phellem may show a diversity of cell types, cell wall thickenings, sclerification and stratification that can be highly diagnostic (Esau 1969; Roth 1981; Evert 2006).

\section{Phellem cells evenly thin-walled (fig. 123)}

Comment: This is a common condition. Examples are described in several Pinaceae by Srivastava (1963) and Krahmer \& Wellons (1973).

\section{Phellem cells evenly thick-walled and sclerified (fig. 124)}

Comments: Lignification/sclerification of phellem cells is very common, especially in older periderms. In many Pinus (Pinaceae) species and numerous tropical species (e.g. Diplotropis (Leguminosae), Torrubia (Nyctaginaceae), cf. Roth 1981) the thickwalled cells develop into heavily lignified stone cells (Evert 2006).

\footnotetext{
shaped thickenings (arrows). Cadia purpurea (Leguminosae), transverse section, ab/s. 127: Phelloid cells (pi). Eugenia uniflora (Myrtaceae), transverse section, by courtesy of Patricia Soffiatti, h/mg. - Scale bar for $121=1 \mathrm{~mm}$; for $122=500 \mu \mathrm{m}$; for $123=100 \mu \mathrm{m}$; for $124=$ $50 \mu \mathrm{m}$; for $125 \& 126=20 \mu \mathrm{m}$; for $127=75 \mu \mathrm{m}$.
} 
107. Phellem cells with U-shaped wall thickenings (fig. 125)

Definition: Inner tangential walls are thickened and sclerified together with adjoining parts of the radial wall.

Comment: Also referred to as horseshoe-shaped thickenings by Parameswaran \& Liese (1970) and Roth (1981), who listed many tropical barks with these unilaterally thickened phellem cells.

108. Phellem cells with inversely U-shaped wall thickenings (fig. 126)

Definition: Outer tangential wall is thickened together with adjoining parts of radial wall.

Comment: Although slightly less common than phellem cells with thickened inner tangential and radial walls, Roth (1981) and Parameswaran \& Liese (1970) list several tropical tree species that have inversely U-shaped thickenings. For instance Nectandra coriacea and Laurus nobilis (Lauraceae) show this feature.

\section{Phelloid cells}

Definition: Cells in the phellem without suberin in their walls (Evert 2006) (fig. 127).

Comments: Phelloid cells may remain thin-walled, but may also develop a thick, lignified, secondary wall. This makes it difficult to separate them from "ordinary" sclerified phellem cells. In the latter, secondary wall deposition and lignification may mask the presence of suberized wall layers in the primary wall region. We therefore recommend to only use the term phelloid cell for thin-walled nonsuberized cells in the phellem, after confirmation with a specific histochemical test for suberin such as Sudan III or IV.

Stratification of the phellem (to be observed in TS)

110. Alternating bands of thin-walled and thick-walled phellem cells (fig. 128) Examples can be found in species of Eucalyptus and Eugenia (Myrtaceae) (Chattaway 1953, 1959), Pinus, Picea, Larix (Pinaceae) (Srivastava 1963), Betula populifolia (Betulaceae), Robinia pseudoacacia (Leguminosae; Waisel et al. 1967), some Cassinoideae (Celastraceae) of southern Africa (Archer \& Van Wyk 1993), several tropical trees (Roth 1981).

\section{Alternating layers of cells with and without dark contents}

Comment: In the older literature phellem layers with dark cell contents have been referred to as phlobaphene cork (Trockenbrodt 1990).

\section{Phellem nonstratified}

Comment: This is the common pattern in angiosperms and conifers (fig. 129). 

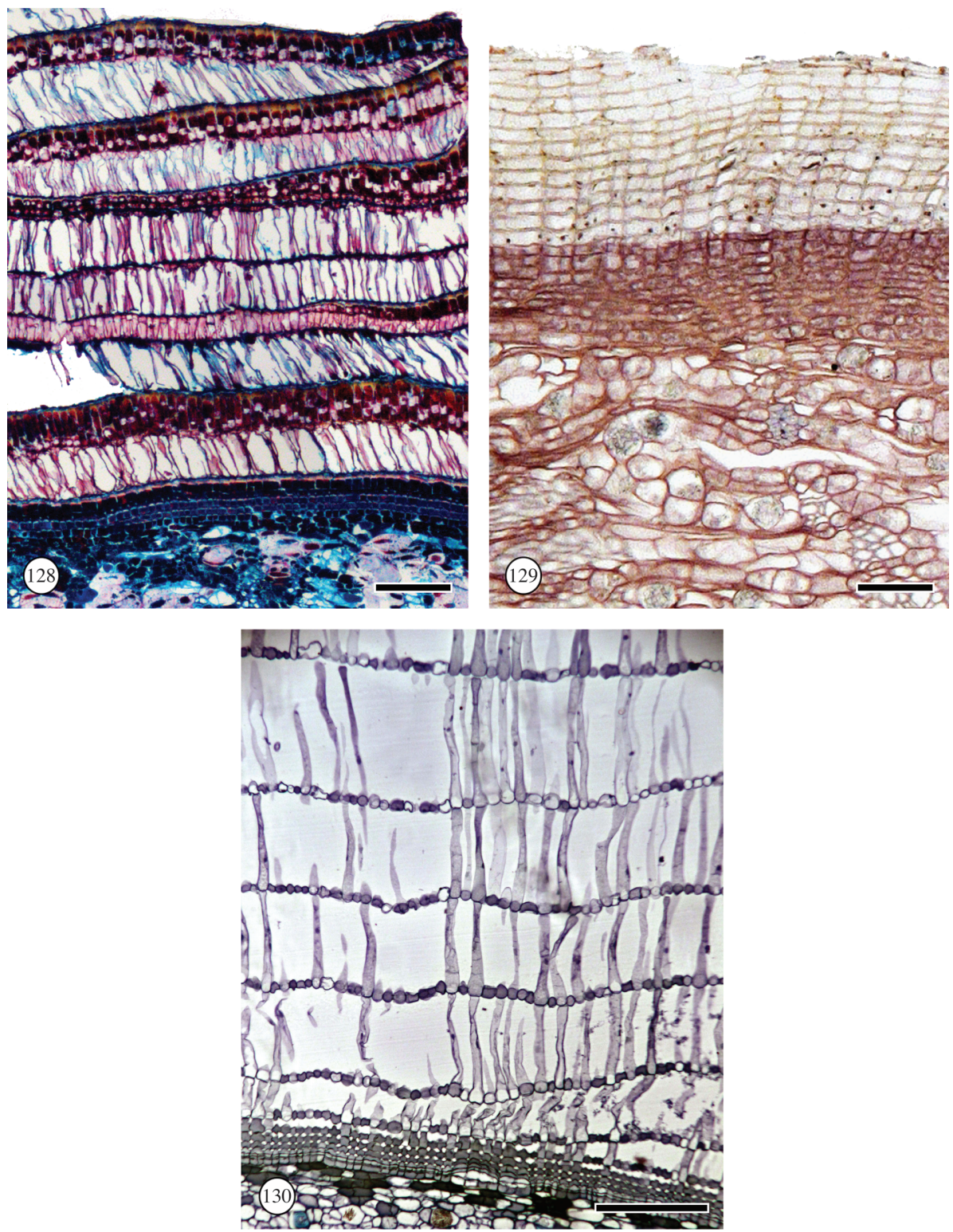

Figure 128-130. - Phellem stratification. - 128: Alternating bands of thin- and thick-walled phellem cells. Curatella americana (Dilleniaceae), ab/s. - 129: Phellem nonstratified. Hibiscus syriacus (Malvaceae), rb/fc. - 130: Aerenchymatous phellem. Ludwigia octavalvis (Onagraceae), rb/fc. - Scale bar for $128=200 \mu \mathrm{m}$; for $129 \& 130=100 \mu \mathrm{m}$. 


\section{Aerenchymatous phellem}

Definition: Phellem containing large intercellular spaces (fig. 130).

Comments: Aerenchymatous phellem or cork aerenchyma occurs in a number of tropical rainforest species (e.g., Alseis labatioides and Coutarea hexandra, Rubiaceae; Parkia pendula, Leguminosae), in which large intercellular spaces arise between radial files of cork cells (Roth 1981). Flooding may induce it as demonstrated by Angeles et al. (1986) and Angeles (1992): in flooded Ulmus americana (Ulmaceae) stems the system of intercellular spaces of the cork was continuous with that of the cortex via intercellular spaces in the phellogen. Cork aerenchyma may be continuous with and resemble the filling tissue of lenticels.

\section{Phelloderm}

Definition: Cells produced centripetally by the phellogen (cork cambium) as part of the periderm, often but not always resembling cortical parenchyma (Evert 2006) (fig. 131-133).

Comment: Although typically much thinner than the phellem, the phelloderm may also show a diversity of cell types and patterns, often paralleling that of the phellem, with the exception that phelloderm cells are not suberized.

\section{Phelloderm thickness}

\section{Thin (1-3 cell layers) (fig. 131)}

Comments: Thin phelloderm is the most common character state. The number of phelloderm cells in the same layer of periderm may change somewhat as the stem ages, and it is therefore (and for many other reasons) important to note the stem diameter when recording this feature. In Tilia (Malvaceae), for example, the phelloderm may be one cell deep in the first year, two in the second, and three or four later. The subsequent periderms formed in later years, contain as much phelloderm as the first or less (Evert 2006).

115. Thick (more than 3 cell layers) (fig. 132)

Comment: Thick phelloderms are present in for instance certain Cucurbitaceae, Malpighiaceae, Brosimum and Ficus (Moraceae) and in certain gymnosperms, notably Pinus (Pinaceae) and Ginkgo (Ginkgoaceae; Evert 2006; Roth 1981).

\section{Cell types and phelloderm stratification}

Comment: Highly specialized phelloderm cells are rare but similar in shape and attributes to those illustrated for the phellem. Therefore, we have not attempted to illustrate all phelloderm cell diversity here. 

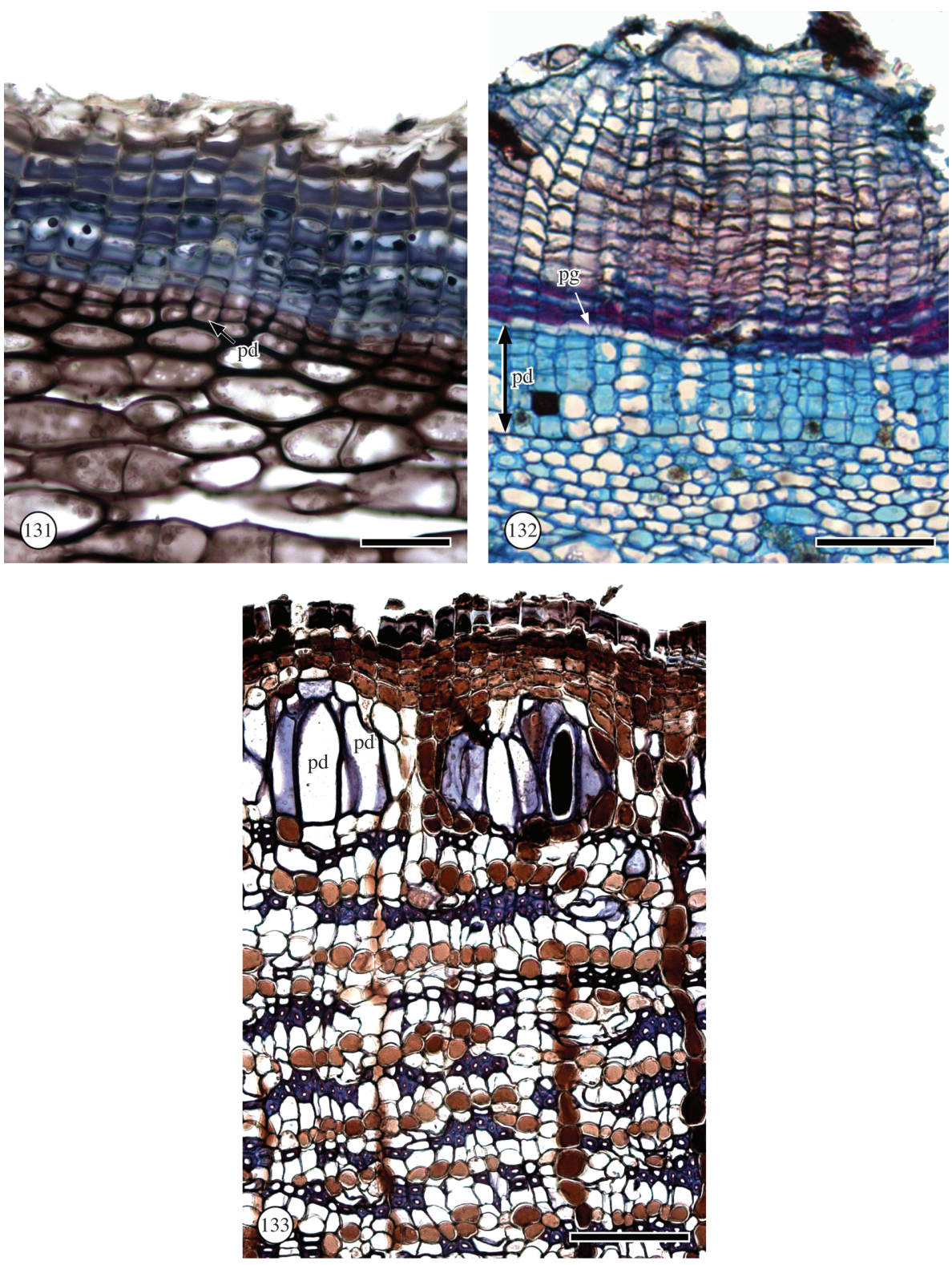

Figure 131-133. - Phelloderm thickness, transverse sections. - 131: Thin phelloderm (pd), 1-3 cells wide. Berberis pruinosa (Berberidaceae), rb/fc. -132 : Thick phelloderm (pd), 4-5 cells thick. Callaeum antifebrile (Malpighiaceae), ab/s. - 133: Radially elongated phelloderm cells (pd). Eucalyptus delegatensis $($ Myrtaceae), $\mathrm{rb} / \mathrm{fc} .-\mathrm{pd}=$ phelloderm, $\mathrm{pg}=$ phellogen.- Scale bar for $131=50 \mu \mathrm{m}$; for $132=100 \mu \mathrm{m}$; for $133=200 \mu \mathrm{m}$. 


\section{Phelloderm cells parenchymatous}

Comments: This is the most common type of phelloderm, only distinguishable from cortical cells by their radial alignment as daughter cells from the phellogen. In many species the phelloderm cells (especially of the first-formed periderms) contain chloroplasts and are photosynthetically active. The parenchymatous elements of the phelloderm may perform a storage function, mainly of starch (Evert 2006). Phelloderm cells may differ in shape from the cortical cells, as in Eucalyptus cloeziana (Myrtaceae) and Curatella (Dilleniaceae), where they are conspicuously erect.

\section{Phelloderm cell walls evenly thickened and sclerified}

Comment: Sclerified phelloderm cells (brachysclereids or stone cells) may occur scattered or in layers alternating with thin-walled phelloderm cells.

\section{Phelloderm cells sclerified with U-shaped or inversely U-shaped wall thickenings}

Comment: Roth (1981) lists a number of tropical tree species with U-shaped or inversely U-shaped wall thickenings in the phelloderm.

\section{Phelloderm consisting of alternating sclerified and nonsclerified cell layers}

Comment: Stratified or layered periderms are rare in temperate species but quite common in tropical trees (Holdheide 1951; Roth 1981).

\section{Phellem and phelloderm cell shape (as seen in TS)}

120. Square and/or rectangular (tangentially elongate)

121. Radially elongate (fig. 133)

Comments: Since both phellem and phelloderm are derived from the same initial, they commonly have similar shapes; however, phellem and phelloderm cells may be very different in their degree of radial elongation. Moreover, within layered phellems or phelloderms the different cell layers may differ strongly in radial expansion (fig. 127 and 128). See also illustrations in Roth (1981).

\section{Lenticels}

Definition: An isolated region in the periderm distinguished from the phellem in having intercellular spaces (fig. 134 \& 135).

Comment: Because of the presence of extensive intercellular spaces that are continuous with those in the inner stem tissues, lenticels are supposed to serve in gas exchange (Groh et al. 2002; Evert 2006).

\section{Filling tissue of lenticels}

Definition: Loose tissue formed by the lenticel phellogen towards the outside: may or may not be suberized. Synonym: complementary tissue (Evert 2006). Based on differences in the filling tissue three types of lenticels have been recognized: 

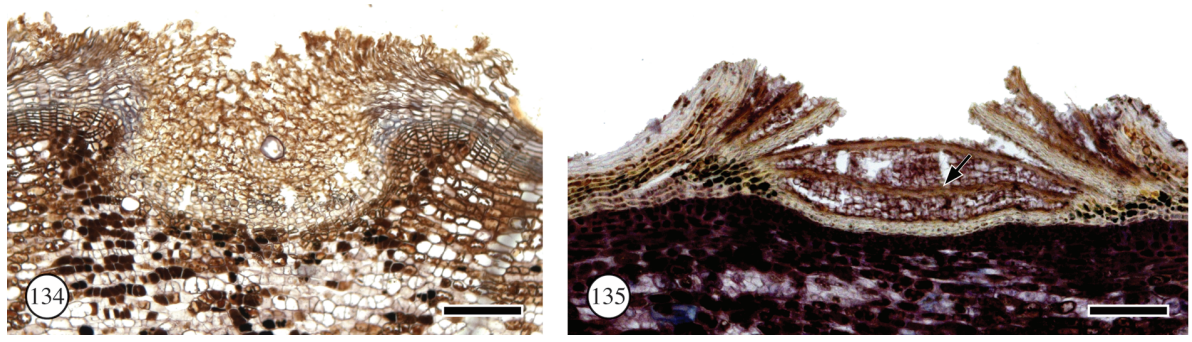

Figure $134 \&$ 135. - Lenticel filling tissues, transverse sections, rb/fc. - 134: Filling tissue nonstratified (homogeneous) and suberized. Persea americana (Lauraceae). Note oil cell in the center of lenticel. - 135: Filling tissue stratified (heterogeneous), with closing layers (arrow). Fagus grandifolia (Fagaceae). - Scale bar for $134 \& 135=200 \mu \mathrm{m}$.

122. Filling tissue nonstratified (homogeneous) and suberized (fig. 134). This is the most simple type of lenticel, occurring for instance in Liriodendron, Magnolia (Magnoliaceae), Malus, Pyrus (Rosaceae), Persea (Lauraceae) and Populus and Salix (Salicaceae) (Evert 2006).

123. Filling tissue nonstratified (homogeneous) and largely nonsuberized. The filling tissue formed during the growing season is nonsuberized; a compact layer of suberized cells is formed at the end of the growing season, e.g. Fraxinus (Oleaceae), Quercus (Fagaceae) and Tilia (Malvaceae) (Evert 2006).

124. Filling tissue stratified (heterogeneous) (fig. 135), composed of alternating layers of loose nonsuberized filling tissues and compact, suberized layers - the so-called closing layers. This type occurs for example in Betula (Betulaceae), Fagus (Fagaceae), Prunus (Rosaceae), Robinia (Leguminosae) (Evert 2006). In Picea abies (Pinaceae) the lenticels usually produce one new closing layer each year (Rosner \& Kartusch 2003).

Comment: Lenticel distribution and shape as seen in surface view are an important macroscopic feature to recognize trees.

\section{Outgrowths of the bark}

\section{Prickles}

Definition: Sharp outgrowths from the bark, without vascular tissue (fig. $136 \&$ 137).

\section{Origin of prickles}

126. Cortex: Formed by radial elongation of the outermost cortical cells without excessive phellogen activity, e.g. Caesalpinia echinata (Leguminosae), Polyscias mollis (Araliaceae, fig. 136).

127. Phellogen: Formed by the phellogen which produces phellem (cork) in excess at certain spots. The cork cells elongate parallel to the long axis of the prickles, which are pure cork formations, consisting of thick-walled lignified cells, e.g. Amphipterygium (Anacardiaceae), Eleutherococcus (Araliaceae) and several Bombacoideae (Malvaceae) (fig. 137). 

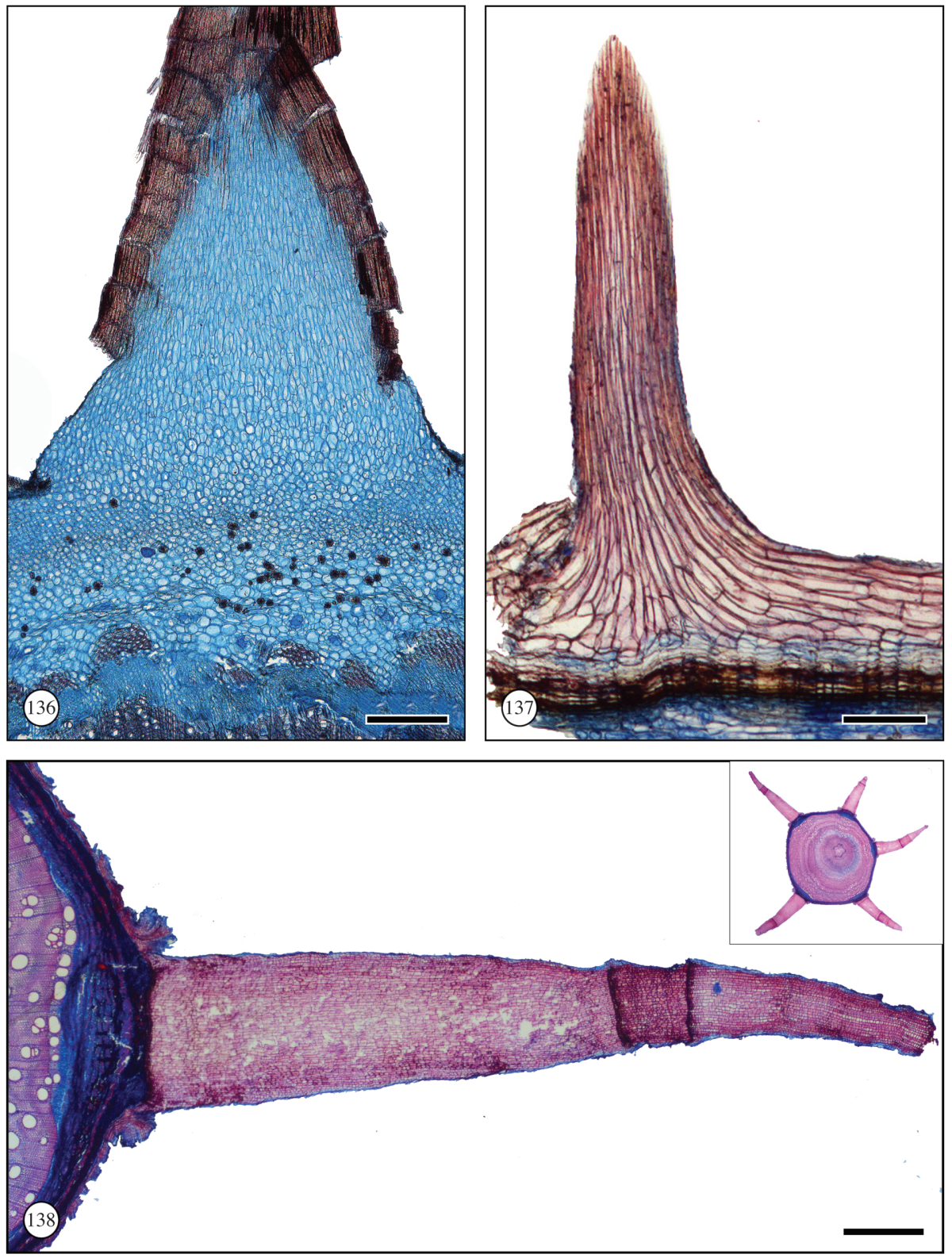

Figure 136-138. - Outgrows of the bark, prickles and wings, transverse sections . - 136: Prickle of cortical origin. Polyscias mollis (Araliaceae), acb/s. - 137: Prickle derived from the phellogen. Oplopanax horridus (Araliaceae), acb/s. - 138: Winged bark. On upper right side distribution of wings in the stem. Piptadenia gonoacantha (Leguminosae), ab/s. - Scale bar for $136=$ $400 \mu \mathrm{m}$; for $137=200 \mu \mathrm{m}$; for $138=4 \mathrm{~mm}$. 
Comments: Prickles (without vasculature) should not be confused with spines (with vasculature and homologous with a leaf or shoot or even roots as in certain palms). Spines do not occur on mature barks. In prickles, abscission layers are sometimes present and the prickles may drop off. Other prickles are long persistent and do not have an abscission layer, e.g. Polyscias mollis (Araliaceae; Kotina \& Oskolski 2010; fig. 136). Sometimes a prickle of cortical origin can further grow out by the formation of a periderm at its base.

\section{Winged bark}

Definiton: Bark with one or more longitudinal, wing-like expansions.

Comment: In some eudicots (e.g. Ulmus, Ulmaceae) winged bark results from a longitudinal splitting of the cork in relation to the uneven expansion of different sectors of the stem, in others from intensive localized activity of phellogen considerably in advance of periderm formation elsewhere (e.g. Euonymus alatus, Celastraceae and Piptadenia gonoacantha, Leguminosae) (fig. 138).

\section{Mineral and organic inclusions}

\section{Preamble}

Composition, shape and distribution of various mineral inclusions (crystals and silica bodies) and solid organic inclusions (starch, fructans, several glycosides, and protein crystals) in bark show a great diversity, of which the most accessible and best known character states are listed. Poorly documented features are briefly discussed in the comment sections.

Crystals and starch are by far the most common bark inclusions. Crystals can be distinguished from the other inclusions by their birefringent nature when viewed under polarized light, and also starch grains show a characteristic (Maltese or extinction) cross under polarized light. It is often assumed that plant crystals are always composed of calcium oxalate, but as stated by Franceschi \& Horner (1980): "Many plant crystals assumed to be Ca oxalate have never been positively identified as such". For example, it is known that strontium, magnesium or barium can replace calcium in plant crystals, and the oxalate ion can be substituted by carbonate, citrate, tartrate, malate, phosphate or sulphate (Netolitzky 1929; Al-Rais et al.1971; Metcalfe 1983b). Even within a single individual, crystals can have different compositions, such as calcium oxalate, calcium sulfate, and a combination of calcium sulphate-magnesium oxalate (e.g. in Acacia robeorum, Leguminosae; He et al. 2012). In order to assess the diagnostic value of the composition of all mineral and organic inclusions in much more detail, we need to combine anatomical studies with analytical techniques unraveling the true composition of plant inclusions (Franceschi \& Horner 1980; Kotina et al. 2015).

Although the dimensions and quantity of bark crystals vary considerably in some species and may be of limited diagnostic value (Trockenbrodt 1995), the occurrence of specific crystal shapes, for instance crystal sand, megastyloids or raphides, can be very helpful in identifying taxa. In bark, crystals are common in parenchymatous cells, such as ray cells, axial parenchyma cells, phelloderm cells, and cortical cells (Holdheide 
1951; Esau 1969), and they are especially common in nonconducting phloem (in case of older stems) or in the cortex (in case of younger stems). Furthermore, there is often a connection between the occurrence of crystals and the presence of bark sclerification, which is exemplified by the high proportion of crystals in (sclerified) phloem and by the presence of many crystal-bearing cells adjacent to fibres and sclereids (Esau 1969); however, exceptions to this link between age-related sclerification and crystal presence abound.

An array of different hypotheses have been proposed about the possible function of crystals in plants: plant defense against herbivory, cellular ion balance (sodium and/or potassium), tissue rigidity and support, detoxifying of oxalic acid and/or heavy metals, light gathering and reflection, and bulk calcium regulation (Franceschi \& Horner 1980; Nakata 2003; Franceschi \& Nakata 2005).

\section{Mineral inclusions}

\section{Crystals}

\section{Comments on chemical composition of the crystals:}

Calcium oxalate $\left(\mathrm{CaC}_{2} \mathrm{O}_{4}\right)$ crystals are the most common type of crystals in plant tissues, and they can occur in a wide range of shapes: prismatic, druses, raphides, acicular, styloids, spherical, cubic, spindle-shaped, crystal sand, with the former two being the most abundant in bark. Calcium carbonate $\left(\mathrm{CaCO}_{3}\right)$ crystals are not common in seed plants, and have only been occasionally observed in barks, such as in the periderm of Capparis (Capparaceae; Metcalfe \& Chalk 1983). The best-known calcium carbonate formations are cystoliths, which are formed in specialized enlarged cells - called lithocysts - of the ground parenchyma and epidermis (Eschrich 1954; Metcalfe \& Chalk 1983; Evert 2006). In barks, cystoliths only occur in taxa with smooth barks with a long persisting epidermis and outer cortex (e.g., some Moraceae). Calcium sulfate $\left(\mathrm{CaSO}_{4}\right)$ crystals are rare in plants, and there are only a few reports on calcium sulfate formation: in pith of stems, and in ray cells of the secondary xylem of Capparis (Capparaceae; Miller 1978; no mentioning of crystals in the rays of the bark). In Acacia rubeorum, calcium sulfate crystals include druses, crystal sand and other aggregates, and they are present in almost all stem and leaf tissues, including mesophyll, parenchyma, sclerenchyma fibers, pith, rays and cortex (He et al. 2012).

\section{Crystal shape}

Comments: Crystal shape or morphological type shows a great diversity, and has been profitably used for diagnostic purposes in plant anatomy and pharmacognosy. In barks as in other plant parts, more than one crystal type may occur together. The crystal shapes listed below mostly apply to Ca-oxalate, but may also be applied to crystalline forms of other mineral or even organic compounds. 
129. Prismatic crystals: solitary rhombohedral or octahedral isodiametric crystals (fig. 139)

Comments: This is one of the most common types of crystals in plants. The term prismatic is actually a misnomer because a prism in crystallography can cover a whole range of shapes with parallel facets. In the literature prismatic crystals are also often referred to as solitary crystals (e.g. Metcalfe \& Chalk 1950,1983).

130. Druses: Compound crystal, more or less spherical in shape, in which the many component crystals protrude from the surface giving the whole structure a starshaped appearance (fig. 140)

Comment: Druses are also a very common type of crystals in barks (more common than in wood). Irregular druses are often called clustered or aggregated crystals.

131. Raphides: Long needle-shaped crystals that occur in bundles (fig. 141)

Comment: Raphides are usually embedded in mucilage and they occur in cells that are often much larger than neighboring cells. Metcalfe \& Chalk (1983) list 27 flowering plant families with raphides in their wood and/or other tissues, most of which probably also have raphides in the bark (e.g. in the Dilleniaceae).

132. Acicular crystals: Small needle-like crystals, not occurring in bundles (fig. 142)

Comment: Metcalfe \& Chalk (1983) provide a list of 36 flowering plant families with acicular crystals in their stems and/or leaves. Richter (1981) put them into synonymy with spindle-shaped crystals which he recorded in wood and bark of many Lauraceae (but see below under "Crystals of other types").

133. Styloids and elongated crystals: Crystals at least four times as long as broad (styloids) or 2-4 times as long as broad (elongated crystals) with at least one pointed end, at most one ridged or square end (fig. $143 \&$ 144)

Comments: Metcalfe \& Chalk (1950) give a comprehensive list of the 27 families with styloids in stems and/or leaves, of which 13 families show styloids in phloem. Very large styloids occurring in for instance some Melastomataceae (Ter Welle \& Mennega 1977) and Quillajaceae (Metcalfe \& Chalk 1950; Lersten \& Horner 2005) are called mega-styloids. Since styloids and somewhat shorter elongated crystals intergrade we treat them here as one category of crystal shape. Elongated crystals with square ends at both sides are also called rod-shaped crystals.

134. Crystal sand: A granular mass composed of very small crystals. Synonym: microcrystals (fig. 145)

Comment: Crystal sand can be highly diagnostic at fairly high taxonomic levels and is therefore also phylogenetically informative. It has been observed in stems and/or leaves of 36 flowering plant families (Metcalfe \& Chalk 1983). 

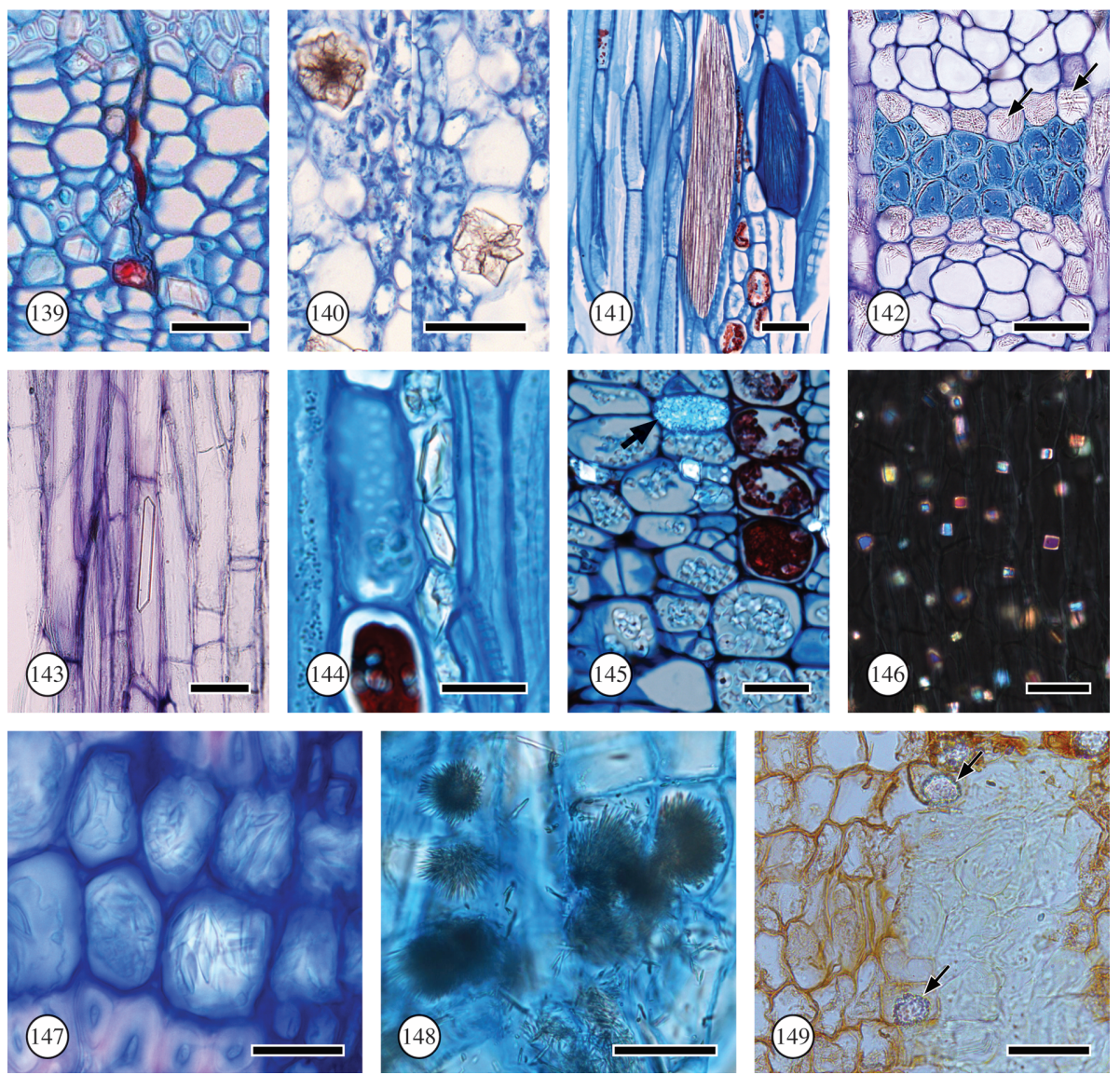

Figure 139-149. - Crystal shapes. - 139: Prismatic crystals. Mimosa velloziana (Leguminosae), transverse section, ab/s. - 140: Druses. Brassaiopsis grushvitzkyi (Araliaceae), radial section, ab/s. - 141: Rhaphides. Actinidia chinensis (Actinidiaceae), tangential section, acb/s. 142: Acicular crystals (arrows). Perianthomega vellozoi (Bignoniaceae), transverse section, tb. - 143: Styloid crystal. Delarbrea harmsii (Myodocarpaceae), tangential section, cv. - 144: Elongate crystals. Taonabo japonica (Pentaphylacaceae), tangential section, acb/s. - 145: Crystal sand (arrow). Manilkara zapota (Sapotaceae), transverse section, acb/s. - 146: Cubical crystals. Lotononis trichodes (Leguminosae), tangential section, under polarized light. - 147: Navicular crystals. Liparia myrtifolia (Leguminosae), transverse section, acb/s. - 148: Acicular crystals in sheaf-like aggregates. Virgilia divaricata (Leguminosae), maceration, ab. - 149: Silica bodies (arrows). Mezilaurus ita-uba (Lauraceae), radial section, n. - Scale bar for 139, 141, 142, 143, $146,148 \& 149=50 \mu \mathrm{m}$; for $140=100 \mu \mathrm{m}$; for $144 \& 145=25 \mu \mathrm{m}$; for $147=20 \mu \mathrm{m}$. 


\section{Crystals of other shapes (mostly small)}

Comments: Apart from the main crystal types listed above there is a whole array of variants in crystal shape that often co-occur in certain plant families and may also intergrade: cubical, diamond-shaped, pyramidal, tabular (synonym tabletoid), navicular, spindle-shaped, indented, and twinned crystals. Some of these minute crystal types may be a component of crystal sand (see above). Sphaerocrystals or sphaerites, and various other aggregates of acicular crystals are also treated in this category, although they may be crystalline precipitations in alcohol or on drying of organic compounds, whilst they are usually in solution in the living bark.

135. Cubical crystals: Type of prismatic crystal, bounded by six square faces, facets or sides - small cubical crystals often co-occur with other types of small crystals (e.g. in Lauraceae, cf. Richter 1981). In conifer barks this type of crystals is quite common (fig. 146).

136. Navicular crystals: Small, boat-shaped crystals (fig. 147). Navicular crystals are sometimes confused with small acicular, prismatic and spindle-shaped crystals, and have been recorded in various families, e.g. Bignoniaceae, Leguminosae, Lauraceae. They may also intergrade in shape with diamond-shaped crystals.

137. Spindle-shaped crystals: small elongate crystals, intermediate between acicular or needle-shaped crystals and slightly elongate diamond-shaped crystals spindle-shaped crystals are considered synonymous with acicular crystals by Richter (1981), and are common in Lauraceae and other magnoliids (Metcalfe 1987).

138. Pyramidal crystals: Small pyramid-shaped crystals. For instance, crystal sand of Sapotaceae is entirely composed of pyramidal crystals (Lens et al. 2007).

139. Diamond-shaped crystals: Diamond- or lozenge-shaped crystals.

140. Tabular crystals: Relatively broad and thin crystals, with two well-developed flat faces (synonym: tabletoid crystals). - Tabular crystals have been well documented and illustrated for the wood and bark of Lauraceae (Richter 1981) and for wood-only of certain Oleaceae (Baas et al. 1988), where they probably also occur in the bark.

141. Indented and twinned crystals: Indented, divided or seemingly merged crystals in a variety of configurations.

142. Acicular crystals in variously-shaped aggregates, such as sheaf-like aggregates: These types of crystal aggregates were found in bark and wood of some members of Podalyrieae-Leguminosae (Calpurnia, Cyclopia, Podalyria and Virgilia; Kotina et al.2013, 2015, Stepanova et al.2013), have organic origin and are probably more widespread (fig. 148).

143. Sphaerites or sphaerocrystals: Aggregate crystalline bodies of spherical shape. Sphaerites are typically composed of numerous, very closely packed, narrow radiating crystals. Calcium sulfate, inuline, hesperidin and other organic inclusions may crystalize as sphaerites (Metcalfe 1983b). Sheaf-like aggregates may intergrade with sphaerites (cf. fig. 148). 


\section{Silica bodies}

Definition: Spheroidal or irregularly shaped particles composed of silicon dioxide deposited in the cell lumina. Synonyms: silica grains (fig. 149).

Comments: Silica bodies have been observed in leaves and wood in a number of families (Metcalfe \& Chalk 1983; Carlquist 2001), but their presence or absence in bark of the same families is often poorly documented. Richter (1981) found silica bodies in both wood and bark of Mezilaurus (Lauraceae), a feature confirmed and illustrated here. Parameswaran \& Liese (1968) reported identical silica bodies in wood and bark tissues of Entandrophragma candollei (Meliaceae). Silica bodies are usually described as opaline ("glassy") and tests have repeatedly demonstrated that they are mostly optically amorphous in spite of their superficial crystalline appearance. In other words, silica bodies are invisible in polarized light, which is the easiest way to separate silica inclusions from crystals. However, silica in crystalline form is also known to occur in certain plants, but is much less frequent. Lanning (1961) recorded the occurrence of crystalline as well as opaline silica in the outer bark of Rubus occidentalis (Rosaceae).

\section{Vitreous silica}

Vitreous or "dense" silica may be present either as an incrustation or impregnation of the cell wall or in the form of translucent deposits in the cell lumina. Richter (1981) found it in various Lauraceae barks. The diagnostic value of vitreous silica is fairly well documented for wood (IAWA Committee 1989; InsideWood 2004-onwards) and leaves (Baas et al. 1982) of a small number of plant families. Whether vitreous silica has the same taxonomic significance in barks remains to be assessed.

\section{Distribution of mineral inclusions}

146. In single axial parenchyma cells

147. In chambered axial parenchyma cells (fig. 150)

148. In ray parenchyma cells (fig. 151)

149. In fibers

150. In sclereids (fig. 152)

151. In cristarque cells (fig. 153)

152. In cell walls (fig. 154)

153. In cortical cells

154. In phelloderm cells (fig. 155)

155. In phellem cells

Comments: As mentioned in the preamble on mineral and organic inclusions, there is a close connection between lignification of the bark and the presence of crystalliferous cells. Additional evidence for this strong link is expressed in the similarity between fibers and crystal-bearing cells in Taxus (Taxaceae) and the frequent substitution of fibers by crystalliferous cells if fibers fail to develop (Pyrus communis (Rosaceae); Evert 1960; Esau 1969). The frequent occurrence of crystalliferous cells adjacent to fiber bands, or of crystals in partly sclerified cells: so-called cristarque cells (see next) are examples of this phenomenon. 
Cristarque cells (fig.153) are a special kind of sclerenchyma cells with unilaterally thickened and lignified, often polylamellate walls containing a prismatic or druse crystal. They have been documented in leaves and stems of assorted families (Metcalfe 1983) but may also occur in the bark (e.g. Huaceae, Baas 1972; Ochnaceae, Somavilla et al. 2013). Cristarque cells have often been overlooked and they are probably quite common in the secondary phloem at the interface of fibre groups/bands or sclereid clusters and parenchyma.
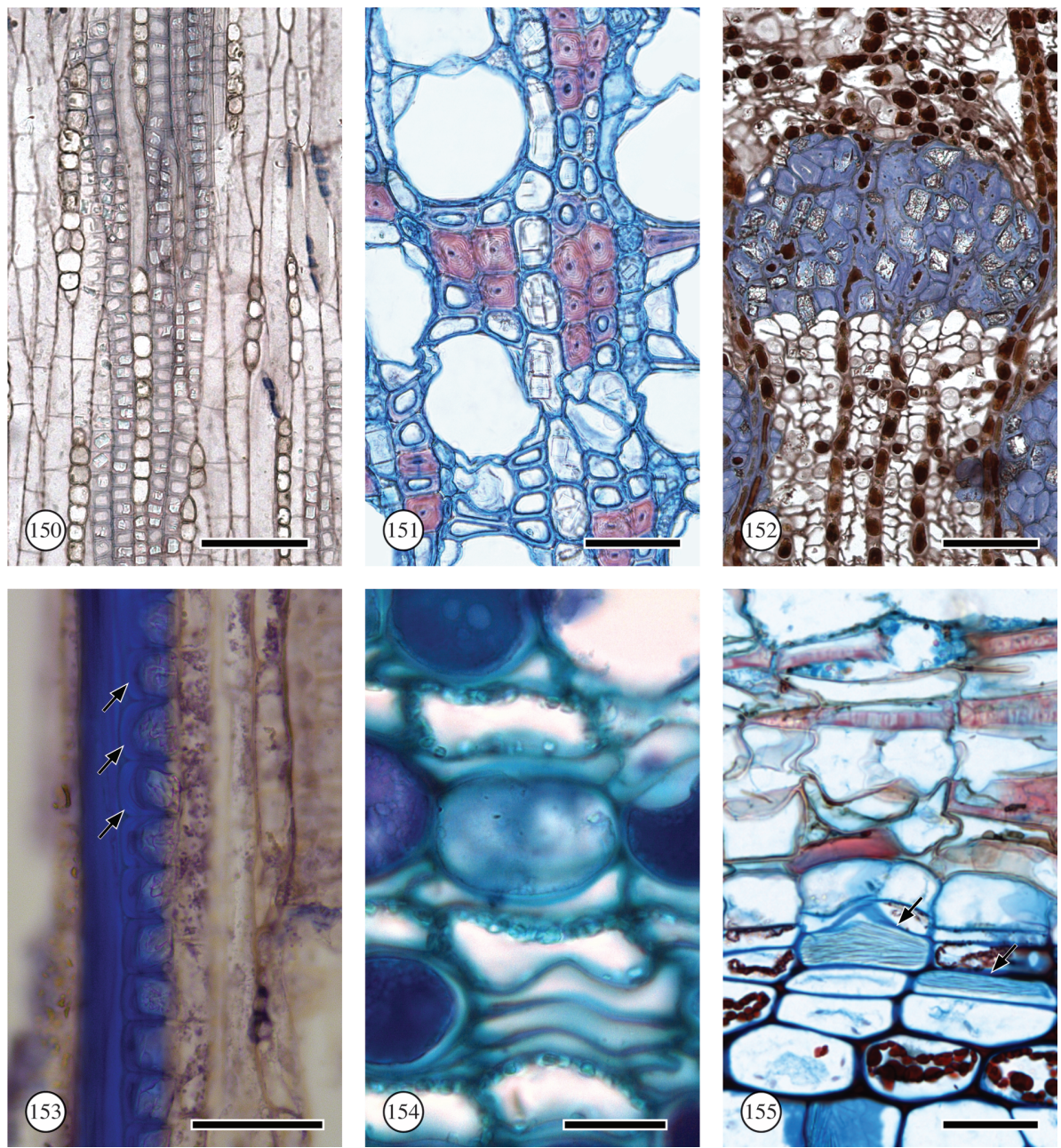

Figure 150-155. - Distribution of mineral inclusions. - 150: In chambered axial parenchyma cells. Castanea dentata (Fagaceae), tangential section, rb/fc. -151 : In ray cells. Pleonotoma tetraquetra (Bignoniaceae), transverse section, ab \& sa. - 152: In sclereids. Crataegus intricata (Rosaceae), transverse section, rb/fc. - 153: In cristarque cells. Populus tremuloides (Salicaceae), radial section, rb/fc. - 154: In cell walls. Taxus globosa (Taxaceae), transverse section, fg/s, under partly polarized light. - 155: In phelloderm. Marcgravia umbellata (Marcgraviaceae), transverse section, acb/s. - Scale bar for $150 \& 152=100 \mu \mathrm{m}$; for $151,153 \& 155=50 \mu \mathrm{m}$; for $154=20 \mu \mathrm{m}$. 
In gymnosperms, calcium oxalate crystals may be deposited in the secondary phloem cell walls of Araucariaceae, Taxaceae, Cupressaceae, Gnetaceae, Ephedraceae and Welwitschiaceae, but not in most Pinaceae (Strasburger 1891; Frey-Wyssling 1935; Hudgins et al. 2003). The crystals may be deposited in the middle lamellae of the radial walls in all kinds of cells (Strasburger 1891; Bamber 1959; Hudgins et al. 2003). Occurrence of crystals in cell walls of the secondary phloem appears to be less common in the angiosperms. According to Bailey \& Nast (1948), the sclereids in the bark of Kadsura and Schisandra (Schizandraceae) deposit prismatic crystals in their walls.

\section{Organic inclusions}

156. Starch: The most common organic inclusion seen in parenchyma cells of the bark, having grains of various shapes (fig. 156) (Czaja 1978).

Starch grains characteristically show a (Maltese or extinction) cross under polarized light (fig. 157), and stain bright purple with IKI (iodine potassium iodide). As a storage carbohydrate, the presence of starch in all plant tissues, including the bark, is subject to very strong seasonal fluctuations, which strongly limits its diagnostic value.

157. Fructans including inulin: Fructans are widely distributed among numerous angiosperm families.

When present in the living bark in solution they may be precipitated as sphaerocrystals when dried or fixed in alcohol. When stored as grains in living parenchyma cells they look like starch grains and show an extinction cross under polarized light (Joaquim et al. 2014). While starch stains bright purple with IKI, inulin grains stain brownish with the same reagent.
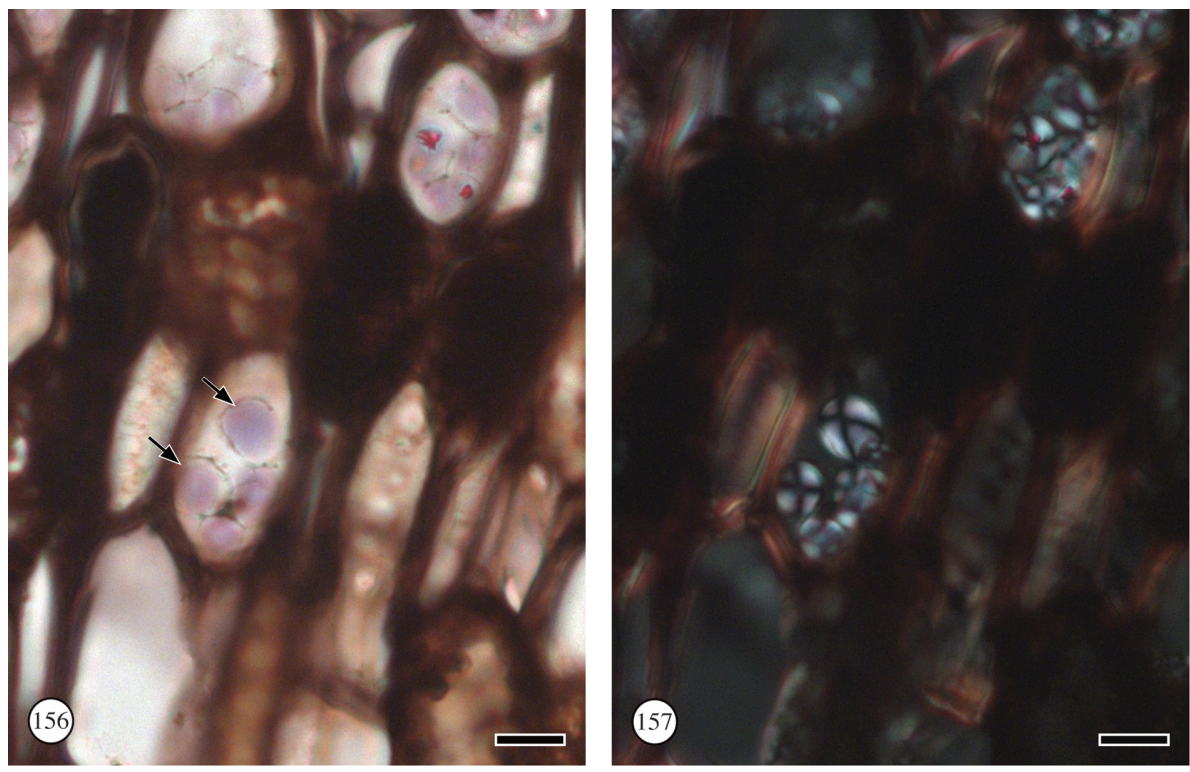

Figure 156 \& 157. - Starch grains. Sideroxylon (Sapotaceae), transverse sections. - 156: Under transmitted light (arrows), rb/fc. -157 : Under polarized light. - Scale bar for $156 \& 157=10 \mu \mathrm{m}$. 


\section{Protein crystals}

Protein crystals are components of so-called P-plastids in sieve tubes that are diagnostic at high taxonomic levels (Behnke 1988, 1991; Evert 1990). They are typically minute and cubical or spindle-shaped and best observed in properly fixed material with transmission electron microscopy (Behnke 1991).

\section{Other organic inclusions}

Comments: Bark tissues can be very rich in secondary metabolites, hence the abundant uses of bark in traditional medicine. Mostly these metabolites occur in the plants in dissolved form, but they can precipitate as crystals on drying or in contact with fixatives or preserving fluids like alcohol. Crystalline forms are known of flavones (including hesperidin and diosmin), glycosides (including myrosin, the mustard oil releasing glycoside typical of Brassicales - see also myrosin cells on page 597), and carotenes. See Metcalfe 1983b for a review of their occasional occurrence in crystalline form in the dicots.

\section{Secretory structures}

\section{General comment}

Barks are often rich in secondary metabolites that may be stored in special cells, cavities, or canals/ducts that are often of high diagnostic value for families, genera or individual species. The compounds stored or exuded are often of great economic value and/or medicinal significance. The commercial production of resins and gums by barks and other plant parts can in certain taxa be stimulated by the induction of traumatic ducts or cavities. The distribution of secretory structures in the bark (cortex, phelloderm and/or secondary phloem) should be recorded.

158. Secretory cells (fig. 158-160)

Definition: Specialized parenchyma cells (usually idoblastic) that synthesize and accumulate substances such as oils, mucilages, tannins and myrosin (not including epithelial cells, which secrete resins or gums into an intercellular duct or cavity).

Comments: The general term secretory cell is recommended in all cases when their contents have not been tested histochemically. Please also observe fresh and unstained material. Although secretory cells are usually classified on the basis of their contents, many contain mixtures of substances.

\section{Oil cells}

Definition: Secretory cells containing oil, usually idioblastic, mostly enlarged and rounded in outline, often axially extended (fig. 158).

Comments: The oil drops, completely filling the lumen at maturity are commonly attached to wall protuberances, often in the shape of a cupule and the cell walls of oil cells contain a suberized layer (Fahn 1979). Oil cells are common in the Magnoliids, such as Annonaceae, Calycanthaceae, Lauraceae, Magnoliaceae, Myristicaceae, and Winteraceae, where they may co-occur with or be replaced by mucilage cells (Baas \& Gregory 1985; Bakker et al. 1991). See Baas \& Gregory (1985) for a comprehensive review of families and genera in which they may occur in leaves, wood and/or bark. 



Figure 158-165. - Secretory structures. - 158: Oil cells (arrows). Annona cherimola (Annonaceae), transverse section, rb/fc. - 159: Mucilage cells/cavities in rays (arrows). Sterculia laurifolia (Malvaceae), radial section, rb/fc. - 160: Tannin cells. Hypocalyptus oxalidifolius (Leguminosae), transverse section, n. - $161 \&$ 162. Laticifers. - 161: Artocarpus integer (Moraceae), radial section, rb/fc. - 162: Jatropha cardiophylla (Euphorbiaceae), tangential section, fg/s. - 163 \& 164. Resin canals, tangential sections, rb/fc. - 163: Branched canal in Spondias mombin (Anacardiaceae). - 164: In rays (arrow). Picea abies (Pinaceae). - 165: Tanniniferous 


\section{Mucilage cells}

Definition: secretory cells containing mucilage, mostly enlarged and rounded in outline, often axially extended (fig. 159).

Comments: Common in e.g. Malvaceae s.l., Cactaceae, Didieraceae, Dipterocarpaceae, Rhamnaceae, and Ulmaceae (Fahn 1979). See Gregory \& Baas (1989) for a comprehensive list of families where they may occur in leaves, wood or bark. In some families (e.g. Malvaceae s.l. and Ulmaceae) groups of mucilage cells may be merged to form mucilage cavities or even canals (Bakker et al. 1991). In the Magnoliids mucilage cells may co-occur or replace oil cells (Bakker et al. 1991). Raphide crystals are often embedded in mucilage (Evert 2006), but these crystalliferous cells are usually not called mucilage cells - see also under Mineral inclusions.

\section{Tannin cells}

Definition: Parenchyma cells containing tannin (fig. 160).

Comments: Tannins are a broad category of phenolic substances that are usually brown in colour and stain dark(er) brown/reddish with vanillin-hydrochloric acid (Gardner 1975). They are of common occurrence in numerous families (e.g. Crassulaceae, Ericaceae, Leguminosae, Fagaceae, Myrtaceae, Rosaceae, and Vitaceae), and many parenchyma cells illustrated in this Bark List are in fact also tannin cells. When phloem or cortex cells senesce (or die, for instance during drying of collections) phenolic substances may oxidize resulting in dark coloring of the contents throughout the tissue. In such cases we do not apply the term tannin cells, but simply call them secretory cells with colored contents.

\section{Myrosin cells}

Definition: Parenchyma cells (idioblasts) containing the enzyme myrosinase in their vacuoles (responsible for releasing mustard oil through the hydrolysis of thioglucosides; Fahn 1979).

Comments: Myrosin cells may vary in shape and size and either be morphologically identical or very distinct from the ground parenchyma cells (Fahn 1979). Little is known of their occurrence and distribution in the bark, but in the eudicots they are typical of families of the order Brassicales (Brassicaceae, Capparidaceae, Resedaceae, and Moringaceae) and Geraniales (Tropaeolum, Limnanthus - see Fahn 1979). Myrosin stains specifical with orcein- $\mathrm{HCl}$, Miller reagent and with lactophenol aniline blue.

\section{Laticifers}

Definition: A very long tube-like cell or a series of connected cells containing latex (fig. 161, 162).

\footnotetext{
tubes continuous between xylem and phloem (arrows). Myristica muelleri (Myristicaceae), radial section, $\mathrm{rb} / \mathrm{fc} .-\mathrm{x}=$ xylem, $\mathrm{ph}=$ phloem . - Scale bar for 158, 160, $161 \& 162=100 \mu \mathrm{m}$; for $159,164 \& 165=200 \mu \mathrm{m}$; for $163=300 \mu \mathrm{m}$.
} 
Comments: Latex is a watery suspension or emulsion of particles of diverse chemical composition. For instance, poly-isoprene hydrocarbon particles yield rubber and gutta percha (Fahn 1979). Laticifers occur both in the axial and radial system of the bark. They have been recorded in various plant parts, including the bark, in more than 20 plant families (Metcalfe \& Chalk 1983), notably Apocynaceae, Asteraceae Euphorbiaceae, and Moraceae.

164. Nonarticulated laticifers (synonyms: simple laticifers or latex cells)

Definition: Unicellular, multinucleate laticifers that may extend throughout the plant body, and originate from initial cells in the embryo.

Comment: Simple laticifers are common in Apocynaceae s.l., Euphorbiaceae and Moraceae (Evert 2006), and may be unbranched as in Cannabis and Vinca or branched as in Ficus (Moraceae) and Nerium (Fahn 1979).

165. Articulated laticifers (synonyms: compound laticifers or latex vessels)

Definition: Single or branched and anastomosing longitudinal series of laticiferous cells. The end walls of these cells may persist or become porous and disappear completely. Comments: Nonanastomosing articulated laticifers are known from e.g. Manilkara (Sapotaceae), and various Convolvulaceae. Branching and anastomosting articulated laticifers occur for instance in Hevea (Euphorbiaceae) (Fahn 1979). Laticifers can only be recognized as simple or compound after extensive anatomical and developmental study. In Apocynaceae articulated laticifers may loose their division walls and become seemingly nonarticulated (Demarco et al. 2006; Demarco \& Castro 2008).

\section{Tanniniferous tubes/tubules}

Definition: Very strongly elongated secretory cells or series of connected cells containing tannins (fig. 165).

Comments: In secondary xylem, tanniniferous tubules are only known from the rays of Myristicaceae (IAWA Committee 1989) and a few Ulmaceae (Zhong et al. 1992) and Leguminosae (Stepanova et al. 2013). Parameswaran and Liese (1970) also recorded tanniniferous tubules in the phloem rays of Myristica fragrans (Myristicaceae), and they may be more common in barks than recorded in the literature.

\section{Secretory intercellular spaces (canals/ducts and cavities)}

Definition: Intercellular spaces commonly lined by specialized secreting epithelial cells. Secretory cavities are short secretory spaces and secretory canals or ducts are long secretory spaces as viewed in LS (Evert 2006) (fig. 163, 164, 166, 167).

Comments: The development of secretory intercellular spaces may be lysigenous (originating after dissolution of cells), schizogenous (originating from an expanding intercellular space by further separation along the compound middle lamella) or a combination of both processes (schizo-lysigenous). At maturity, when an epithelium has differentiated along the cavity, it is often impossible to deduce the precise development, and we therefore refrain from categorizing secretory intercellular spaces according to 
their ontogeny. Secreted substances (resins, oleoresins, or gums) are accumulated into a large intercellular space called lumen. Because the chemical composition of gums and resins is so diverse, and often remains untested in anatomical studies, it is recommended to use the neutral term secretory cavities or ducts when not sure about the composition of the exudate.
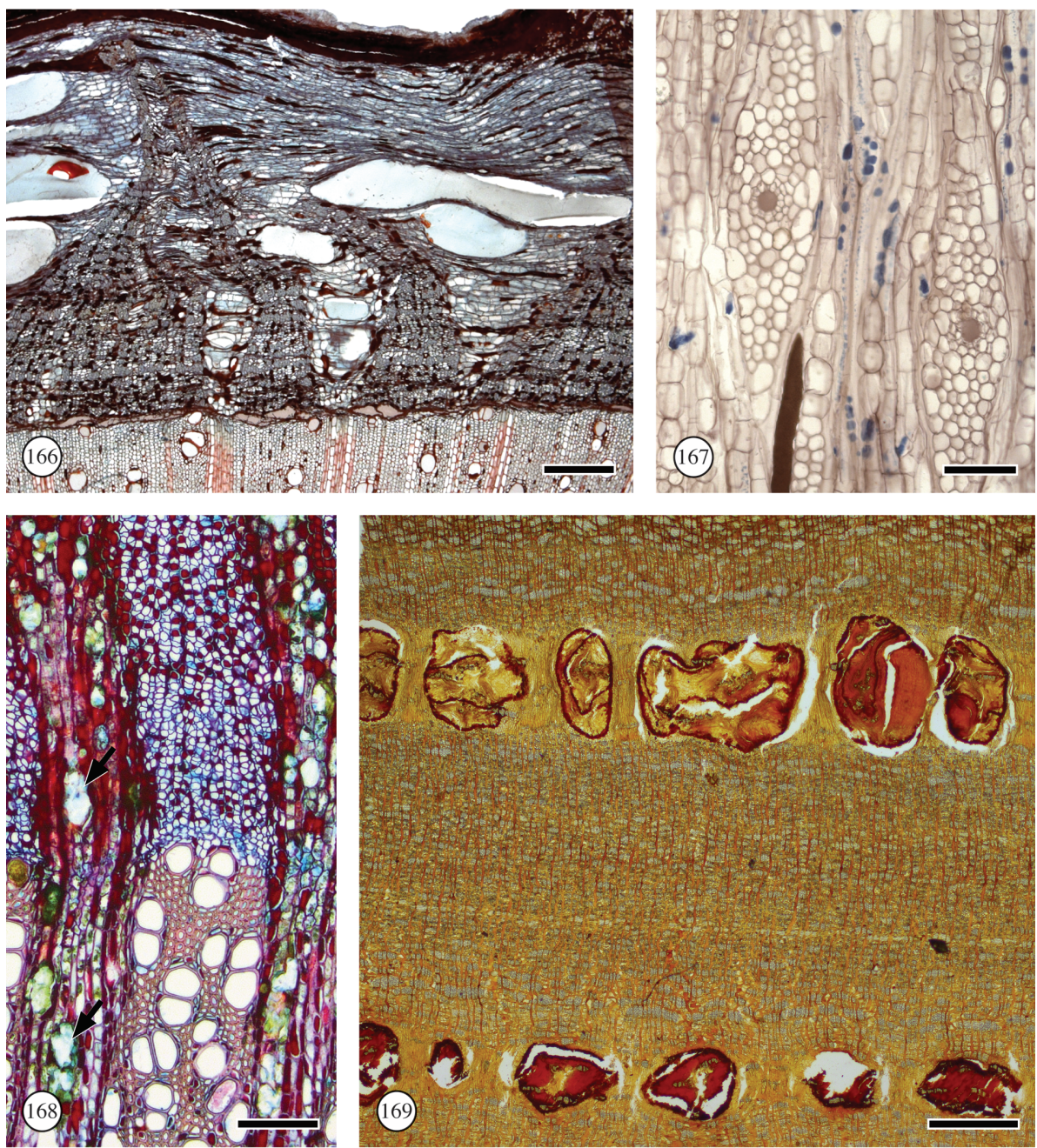

Figure 166-169. - Secretory structures. - 166: Mucilage cavities. Theobroma cacao (Malvaceae), transverse section, rb/fc. - 167: Gum-resin ducts in the rays. Commiphora harveyi (Burseraceae), tangential section, rb/fc. - 168: Breakdown ray areas in both xylem and phloem (arrows). Myrsine parvifolia (Primulaceae), transverse section, ab/s. - 169: Kino veins. Eucalyptus siderophloia (Myrtaceae), transverse section, $\mathrm{n}$. - Scale bar for $166=300 \mu \mathrm{m}$; for $167=$ $100 \mu \mathrm{m}$; for $168=200 \mu \mathrm{m}$; for $169=500 \mu \mathrm{m}$. 


\section{Secretory epithelium present}

Definition of epithelium: Specialized secretory cells lining an intercellular cavity or duct. The epithelium may be single- or multilayered (fig. 163, 164, 167).

Comment: We include here the presence (or absence) of an epithelium as extra character state - overlapping with the majority of resin ducts/cavities and some gum ducts/cavities.

\section{Resin ducts}

Definition: Axial or radial intercellular canals containing resin - substances soluble in organic solvents, of great chemical diversity (fig. 163 \& 164).

Comments: Resin ducts are very common in conifers and also occur in several angiosperm families, e.g. Anacardiaceae, Apiaceae, Araliaceae, Burseraceae. They are typically provided with a distinct epithelium. Anatomically resin ducts can be very similar if not identical to gum ducts. Intercellular canals containing so-called gum resins constitute an intermediate category further linking resin ducts with gum ducts.

\section{Gum ducts}

Definition: Axial or radial intercellular canals containing gums - water soluble polysaccharides of great chemical diversity (fig. 167).

Comments: Because of the poor definition of gums, they overlap with mucilage canals as well as resin ducts and kino veins. Unlike mucilage canals sensu stricto they may have a distinct epithelium. Gum ducts have been reported for many families where they may either be of common occurrence or of traumatic origin. For instance, traumatic gum ducts of Senegalia senegal ( Acacia, Leguminosae) and other species of Acacia/ Senegalia produce gum arabic.

\section{Mucilage cavities or canals}

Definition: Cavities/canals (of limited or indeterminate length) of varying shapes, containing mucilage (mainly polysaccharides; Evert 2006) (fig. 166).

Comment: Some mucilage canals/cavities do not have an epithelium. They originate from fusion of mucilage cells. Common in Dipterocarpaceae, Malvaceae (including Sterculiaceae) (Fahn 1979).

\section{Breakdown ray areas}

Definition: Cavities originating from the breakdown of ray cells and storing lipids and hydrobenzoquinone (fig. 168).

Comment: This feature is unique to both the wood and bark of Myrsinoideae (Primulaceae) (Lens et al. 2005).

\section{Kino veins}

Definiton: A special category of traumatic intercellular secretory canals or cavities containing kino (fig. 169). 
Comments: Kino is a reddish polyphenolic exudate (condensed tannins, proanthoyanoidins). Kino veins occur in the bark of some members of the subgenus Symphyomyrtus of Eucalyptus (Myrtaceae) (Tippett 1986) and a number of other taxa (Hillis 1987). In both wood and bark the kino veins are initiated by lysigenous breakdown of parenchyma bands produced by the vascular cambium. Although referred to as gum in times past, kino contains polyphenols, some of which are tannins. The kino veins commonly form a dense, tangentially anastomosing network (Evert 2006).

\section{NON-ANATOMICAL INFORMATION}

\section{Habit}

174. Tree

175. Shrub

176. Vine/Liana

\section{Name \& geographical distribution}

177. Family, genus, species, authority

\section{Geographical distribution}

Comments: See the IAWA Hardwood and Softwood Lists (IAWA Committee 1989, 2004) for advice on how to code for plant habit, plant name and taxonomy, and geographical distribution. Depending on the aims of a specific study, habit and geographical distribution can be coded in a much more refined way than recommended in the IAWA Hard- and Softwood Lists. 


\section{REFERENCES}

Ahuja I, Borgen BH, Hansen M, Honne BI, Müller C, Rohloff J, Rossiter JT \& Bones AM. 2011. Oilseed rape seeds with ablated defence cells of the glucosinolate-myrosinase system. Production and characteristics of double haploid MINELESS plants of Brassica napus L. J. Experim. Bot. 62: 4975-4993.

Alfieri FJ \& Evert RF. 1968. Seasonal development of the secondary phloem in Pinus. Amer. J. Bot. 55: 518-528.

Alfieri FJ \& Evert RF. 1973. Structure and seasonal development of secondary phloem in Pinaceae. Bot. Gaz. 134: 17-25.

Alfieri FJ \& Kemp RI. 1983. The seasonal cycle of phloem development in Juniperus californica. Amer. J. Bot. 70: 891-896.

Al-Rais AH, Myers A \& Watson L. 1971. The isolation and properties of oxalate crystals from plants. Ann. Bot. 35: 1213-1218.

Amano E, Angyalossy V \& Soffiatti P. 2003. Aspectos da atividade cambial em Cordia trichotoma (Boraginaceae). In: 54 Congresso Nacional de Botânica, Belém-Ananindeua.

Andréasson E, Jørgensen LB, Höglund AS, Rask L \& Meijer J. 2001. Different myrosinase and idioblast distribution in Arabidopsis and Brassica napus. Plant Physiol. 127: 1750 1763.

Angeles G. 1992. The periderm of flooded and non-flooded Ludwigia octovalvis (Onagraceae). IAWA Bull. n.s. 13: 195-200.

Angeles G, Evert RF \& Kozlowski TT. 1986. Development of lenticels and adventitious roots in flooded Ulmus americana seedlings. Canad. J. For. Res. 16: 585-590.

Angyalossy V, Angeles G, Pace MR, Lima AC, Dias-Leme, C, Lohmann LG \& Madero-Vega C. 2012. An overview of the anatomy, development and evolution of the vascular system of lianas. Plant Ecol. \& Diversity 5: 167-182.

Angyalossy V, Marcati CR, Amano E \& Evert RF. 2007. The phloem of tropical trees. IAWA Pan-American Conference, San Luis Potosí.

Angyalossy V, Pace MR \& Lima AC. 2015. Liana anatomy: a broad perspective on structural evolution of the vascular system. In: Schnitzer SA, Bongers F, Burnham RJ \& Putz FE (eds.), Ecology of lianas: 253-287. Wiley Blackwell \& Sons, West-Sussex.

Archer RH \& Van Wyk AE. 1993. Bark structure and intergeneric relationships of some southern African Cassinoideae (Celastraceae). IAWA J. 14: 35-53.

Artschwager E. 1950. The time factor in the differentiation of the secondary xylem and phloem in pecan. Amer. J. Bot. 37: 15-24.

Baas P. 1972. Anatomical contributions to plant taxonomy II. The affinities of Hua Pierre and Afrostyrax Perkins et Gilg. Blumea 20: 161-192.

Baas P, Esser PM, Van der Westen MET \& Zandee M. 1988. Wood anatomy of the Oleaceae. IAWA Bull. n.s. 9: 103-182.

Baas P \& Gregory M. 1985. A survey of oil cells in the dicotyledons with comments on their replacement by and joint occurrence with mucilage cells. Israel J. Bot. 34: 167-186.

Baas P, Van Oosterhout E \& Scholtes CJL. 1982. Leaf anatomy and classification of the Olacaceae, Octoknema and Erythropalum. Allertonia 3: 155-210.

Bailey IW \& Nast CG. 1948. Morphology and relationships of Illicium, Schisandra and Kadsura. I. Stem and leaf. J. Arnold Arbor. 29: 77-89.

Bakker ME \& Gerritsen AF. 1992. The development of mucilage cells in Hibiscus schizopetalus. Acta Bot. Neerl. 41: 31-42.

Bakker ME, Gerritsen \& Van der Schaaf PJ. 1991. Development of oil and mucilage cells in Cinnamomum burmanni. An ultrastructural study. Acta Bot. Neerl. 40: 339-356. 
Bamber RK. 1959. Anatomy of the barks of five species of Callitris Vent. Proc. Linnean Soc. South Wales 84: 375-381.

Barbosa ACF, Pace MR, Witovisk L \& Angyalossy V. 2010. A new method to obtain good slides of heterogeneous plant parts. IAWA J. 31: 373-383.

Behnke HD. 1988. Sieve-element plastids, phloem protein, and the evolution of flowering plants: III. Magnoliidae. Taxon 37: 699-732.

Behnke HD. 1991. Distribution and evolution of forms and types of sieve-element plastids in the dicotyledons. Aliso 13: 167-182.

Behnke HD \& Sjolund RD. 1990. Sieve elements - Comparative structure, induction and development. Springer-Verlag, Berlin.

Bennet HS, Wyrick AD, Lee SW \& McNeil JH. 1976. Science and art in preparing tissues embedded in plastic for light microscopy, with special reference to glycol methacrylate, glass knives and simple stains. Stain Technol. 51: 71-97.

Blaydes GW. 1943. Staining inulin crystals in plant tissues. Ohio J. Sci. 43: 81-82.

Blyth ACB. 1958. Origin of primary extraxylary stem fibers in dicotyledons. University of California Press, Berkeley.

Bonnemain J-L. 1969. Le phloème interne et le phloème inclus des dicotylédones: leur histogénèse et leur physiologie. Rev. Gén. de Bot. 76: 5-36.

Brook PJ. 1951. Vegetative anatomy of Carpodetus serratus Forst. Trans. Roy. Soc. New Zeal. 79: 276-285.

Bukatsch F. 1972. Bemerkungen zur Doppelfärbung Astrablau-Safranin. Microkosmos 61: 255.

Carlquist S. 1982. The use of ethylenediamine in softening hard plant structures for paraffin sectioning. Stain Technol. 57: 311-317.

Carlquist S. 2001. Comparative wood anatomy. Systematic, ecological, and evolutionary aspects of dicotyledon wood, 2nd ed. Springer-Verlag, Berlin.

Carlquist S. 2007. Successive cambia revisited: ontogeny, histology, diversity, and functional significance. J. Torrey Bot. Soc. 134: 301-332.

Carlquist S. 2013. Interxylary phloem: diversity and functions. Brittonia 65: 477-495.

Castro MM \& Demarco D. 2008. Phenolic compounds produced by secretory structures in plants: a brief review. Natural Products Communications (Online) 3: 1273-1284.

Chamberlain CJ. 1935. Methods in plant anatomy. 4th ed. Unversity of Chicago Press, Chicago.

Chattaway M. 1933. Tile-cells in the rays of the Malvales. New Phytol. 32: 261-273.

Chattaway M. 1951. Morphological and functional variations in the rays of pored timbers. Austral J. Sci. Res. 4: 12-27.

Chattaway M. 1953. The anatomy of bark. I. The genus Eucalyptus. Austral. J. Bot. 3: 23-27.

Chattaway M. 1959. The anatomy of bark. VII. Species of Eugenia (sens. lat.). Trop. Woods 111: $1-14$.

Cheadle VI, Gifford EM \& Esau K. 1953. A staining combination for phloem and contiguous tissues. Stain Technol. 28: 49-53.

Chodat R \& Vischer W. 1917. La végétation du Paraguay: résultats scientifiques d'une mission botanique suisse au Paraguay. V. Malpighiacées. Bull. Soc. Bot. Genève 9: 55-107.

Costa AF. 1982. Farmacognosia. Farmacognosia Experimental. v. 3, 2nd ed. Fundação Calouste Gulbenkian, Lisboa.

Crivellaro A \& Schweingruber FH. 2013. Atlas of wood, bark and pith anatomy of eastern Mediterranean trees and shrubs: with a special focus on Cyprus. Springer, Berlin.

Crivellaro A \& Schweingruber FH. 2015. Stem anatomical features of dicotyledons: xylem, phloem, cortex and periderm characteristics for ecological and taxonomical analyses. Kessel Publishing House, Remagen-Oberwinter, Germany.

Czaja AT. 1978. Structure of starch grains and the classification of vascular plant families. Taxon 27: 463-470. 
Davis JD \& Evert RF. 1968. Seasonal development of the secondary phloem in Populus tremuloides. Bot. Gaz. 128: 1-8.

Demarco D \& Castro MM. 2008. Laticíferos articulados anastomosados em espécies de Asclepiadeae (Asclepiadoideae, Apocynaceae) e suas implicações ecológicas. Rev. Brasil. Bot. 31: 699-711.

Demarco D, Kinoshita LS \& Castro MM. 2006. Laticíferos articulados anastomosados? Novos registros para Apocynaceae. Rev. Brasil. Bot. 29: 133-144.

Derr WF \& Evert RF. 1967. The cambial and seasonal development of the phloem in Robinia pseudoacacia. Amer. J. Bot. 54: 147-157.

Deshpande BP \& Rajendrababu T. 1985. Seasonal changes in the structure of the secondary phloem of Grewia tiliaefolia, a deciduous tree from India. Ann. Bot. 56: 61-71.

Eames AJ \& MacDaniels LH. 1947. An introduction to plant anatomy. 2nd ed. MacGrawHill, New York.

Esau K. 1969. The phloem. In: Ozenda P, Wulff HD \& Zimmermann W (eds.), Handbuch der Pflanzenanatomie, Band 5, Teil 2. Borntraeger, Berlin.

Esau K. 1979. Phloem. In: Metcalfe CR \& Chalk L (eds.), Anatomy of the dicotyledons. 2nd ed. pp. 191-189. Clarendon Press, Oxford.

Esau K \& Cheadle VI. 1958. Wall thickening in sieve elements. Proc. National Acad. Sci. USA 44: 546-553.

Esau K \& Cheadle VI. 1984. Anatomy of the secondary phloem of Winteraceae. IAWA Bull. n.s. 5: $13-43$.

Eschrich W. 1954. Ein Beitrag zur Kenntnis der Kallose. Planta 44: 532-542.

Evert RF. 1960. Phloem structure in Pyrus communis L. and its seasonal changes. University of California Publications in Botany 32: 127-194.

Evert RF. 1963a. Companion cells in Tilia americana. Bot. Gaz. 124: 262-264.

Evert RF. 1963b. The cambium and seasonal development of the phloem of Pyrus malus. Amer. J. Bot. 50: 8-37.

Evert RF. 1990. Dicotyledons. In: Behnke H-D \& Sjolund RD (eds.), Sieve elements - Comparative structure, induction and development. pp. 103-138. Springer-Verlag, Berlin.

Evert RF. 2006. Esau's Plant Anatomy: meristems, cells, and tissues of the plant body - their structure, function, and development. 3rd ed. John Wiley \& Sons, Inc, New Jersey.

Fahn A. 1974. Plant anatomy. 2nd ed. Pergamon Press, New York.

Fahn A. 1979. Secretory tissues in plants. Academic Press, London.

Feder N \& O'Brien TP. 1968. Plant microtechnique: some principles and methods. Amer. J. Bot. 55: 123-139+ 141-142.

Fisher DB. 1968. Protein staining of ribboned epon sections for light microscopy. Histochemie 16: 92-96.

Foster AS. 1949. Practical plant anatomy. Ed. 2. D. Van Nostrand, New York.

Franceschi VR \& Horner HT. 1980. Calcium oxalate crystals in plants. Bot. Review 46: 361-427.

Franceschi VR \& Nakata PA. 2005. Calcium oxalate in plants: formation and function. Annual Rev. Plant Biol. 56: 41-71.

Franklin GL. 1945. Preparation of sections of synthetic resins and wood-resin composites, and a new macerating method for wood. Nature J. 155: 3924-3951.

Frey-Wyssling A. 1935. Die Stoffausscheidung der höheren Pflanzen. Verlag von Julius Springer, Berlin, Germany.

Fukuda Y. 1967. Anatomical study of the internal phloem in the stems of dicotyledons, with special reference to its histogenesis. J. Fac. Sci. Univ. Tokyo III, 9: 313-375.

Furr M \& Mahlberg PG. 1981. Histochemical analyses of laticifers and glandular trichomes in Cannabis sativa. J. Natural Products 44: 153-159. 
Gardner RO. 1975. Vanillin-hydrochloric acid as a histochemical test for tannin. Stain Technol. 50: 315-317.

Gärtner H \& Schweingruber FH. 2013. Microscopic preparation techniques for plant stem analysis. Verlag Dr. Kessel.

Grahan PB. 1984. Plant histochemistry and cytochemistry. Academic Press, London.

Gregory M \& Baas P. 1989. A survey of mucilage cells in vegetative organs of the dicotyledons. Israel J. Bot. 38: 125-174.

Groh B, Hübner C \& Lendzian KJ. 2002. Water and oxygen permeance of phellems isolated from trees: the role of waxes and lenticels. Planta 215: 794-801.

Hamann T, Smets E \& Lens F. 2011. A comparison of paraffin and resin-based techniques used in bark anatomy. Taxon 60: 841-851.

He H, Bleby TM, Veneklaas EJ, Lambers H \& Kuo J. 2012. Morphologies and elemental compositions of calcium crystals in phyllodes and branchlets of Acacia robeorum (Leguminosae: Minosoideae). Ann. Bot. 109: 887-896.

Hérail MJ. 1885. Note sur l'anatomie de la tige des Strychnos. Bull. Soc. Bot. France 32: 92-95

High OB. 1984. Lipid histochemistry. Oxford University Press, New York.

Hillis WE. 1987. Heartwood and tree exudates. Springer Verlag, Berlin.

Höglund AS, Lenman M, Falk A \& Rask L. 1991. Distribution of myrosinase in rapeseed tissues. Plant Physiol. 95: 213-221.

Holdheide W. 1951. Anatomie mitteleuropäischer Geholzrinden. In: Freund H (ed.), Handbuch der Mikroskopie in der Technik, Vol. 5, Umschau Verlag, Frankfurt am Main.

Huber B. 1939. Das Siebröhrensystem unserer Bäume und seiner jahreszeitlichen Veränderungen. Jahrb. Wiss. Bot. 88: 176.

Hudgins JW, Krekling T \& Franceschi VR. 2003. Distribution of calcium oxalate crystals in the secondary phloem of conifers: a constitutive defense mechanism? New Phytol. 159: 677-690.

IAWA Committee. 1933. Glossary of terms used in describing woods. Trop. Woods 36: 1-13.

IAWA Committee. 1964. Multilingual glossary of terms used in wood anatomy. Konkordia, Winterthur.

IAWA Committee. 1989. IAWA list of microscopic features for hardwood identification. IAWA Bull.n.s. 10: 219-332.

IAWA Committee. 2004. IAWA list of microscopic features for softwood identification. IAWA J. 25: 1-70.

InsideWood. 2004-onwards. Published on the Internet. http://insidewood.lib.ncsu.edu/search. Jayabalan M \& Shah JJ. 1986. Histochemical techniques to localize rubber in guayale (Parthnium argentatum Gray). Stain Technol. 61: 303-308.

Jenke RU. 1971. Secondary phloem structure and development in Carya ovata. Wisconsin State University, La Crosse.

Jensen WA. 1962. Botanical histochemistry. WH Freeman \& Co, San Francisco.

Joaquim EO, Figueiredo-Ribeiro RCL, Hayashi AH \& Carvalho MAM. 2014. Inulin contents and tissue distribution in underground storage organs of Asteraceae species from the Brazilian rocky fields. Botany 92: 827-836.

Johansen DA. 1940. Plant microtechnique. McGraw-Hill, New York.

Junikka L. 1994. Survey of English macroscopic bark terminology. IAWA J. 15: 3-45.

Keating RC. 2014. Preparing plant tissues for ligth microscopy study: a compendium of simple techniques. Missouri Botanical Garden Press, St. Louis.

Kotina E \& Oskolski AA. 2010. Survey of the bark anatomy of Araliaceae and related genera. Plant Diversity and Evolution 128: 455-489. 
Kotina EL, Oskolski AA, Stepanova AV, Tilney PM \& Van Wyk BE. 2013. Notes on the taxonomic and ecological significance of bark structure in the genus Virgilia (Fabaceae, Podalyrieae). South Afr. J. Bot. 89: 240-243.

Kotina EL, Stepanova AV, Oskolski AA, Tilney PM \& Van Wyk BE. 2015. Crystal types and their distribution in the bark of African genistoid legumes (Fabaceae tribes Sophoreae, Podalyrieae, Crotalarieae and Genisteae). Bot. J. Linn. Soc. 178: 620-632.

Krahmer RL \& Wellons JC. 1973. Some anatomical and chemical characteristics of Douglas-fir cork. Wood Sci. 6: 97-105.

Kukachka BF. 1977 Sectioning refractory woods for anatomical studies. U.S.D. A. Forest Service Research Note FPL-0236: 1-9 (Also in Microscopica Acta 80: 301-307, 1978).

Lanning FC. 1961. Silica and calcium deposits in black raspberries. Proc. Amer. Soc. Horticult. Sci. 77: 367-371.

Lens F, Davin N, Smets E \& Arco M. 2013. Insular woodiness on the Canary Islands: a remarkable case of convergent evolution. Intern. J. Plant Sci. 174: 992-1013.

Lens F, Groeninckx I, Smets E \& Dessein S. 2009. Woodiness within the SpermacoceaeKnoxieae alliance (Rubiaceae): retention of the basal woody condition in Rubiaceae or recent innovation? Ann. Bot. 103: 1049-1064.

Lens F, Jansen S, Caris P, Serlet L \& Smets E. 2005. Comparative wood anatomy of the primuloid clade (Ericales s.l.). Syst. Bot. 30: 163-183.

Lens F, Schöneberger J, Baas P, Jansen S \& Smets E. 2007. The role of wood anatomy in phylogeny reconstruction of Ericales. Cladistics 23: 229-254.

Lersten NR \& Horner HT. 2005. Macropattern of styloid and druse crystals in Quillaja (Quillajaceae) bark and leaves. Intern. J. Plant Sci. 166: 705-711.

Lev-Yadun S. 1991. Terminology used in bark anatomy: additions and comments. IAWA Bull. n.s. 12: 207-209.

Lillie RD. 1948. Histopathologic technic. Blakiston, Philadelphia.

Mace ME \& Howell CR. 1974. Histochemistry and identification of condensed tannin precursor in roots of cotton seedlings. Canad. J. Bot. 52: 2423-2426.

Metcalfe CR. 1983a. Anomalous structure. In: Metcalfe CR \& Chalk L (eds.), Anatomy of the Dicotyledons, vol. 2, 2nd ed. Wood structure and conclusion of the general introduction, pp. 52-63. Clarendon Press, Oxford.

Metcalfe CR. 1983b. Calcareous deposits, calcified cell walls, cystoliths, and similar structures. In: Metcalfe CR \& Chalk L (eds.), Anatomy of the Dicotyledons, vol. 2, 2nd ed. Wood structure and conclusion of the general introduction, pp.94-97. Clarendon Press, Oxford.

Metcalfe CR. 1987. Anatomy of the Dicotyledons, vol. 3, 2nd ed. Magnoliales, Illiciales, and Laurales. Clarendon Press, Oxford.

Metcalfe CR \& Chalk L. 1950. Anatomy of the Dicotyledons. Clarendon Press, Oxford.

Metcalfe CR \& Chalk L. 1979. Anatomy of the Dicotyledons. Vol. 1, ed. 2, Systematic anatomy of leaf and stem, with a brief history of the subject. Clarendon Press.

Metcalfe CR \& Chalk L. 1983. Anatomy of the Dicotyledons, 2nd ed., vol. 2 Wood structure and conclusion of the general introduction. Clarendon Press, Oxford.

Milanez FR. 1960/1961. Contribuição ao conhecimento anatômico de Cryptostegia grandiflora. II. Sobre os laticíferos da estrutura primária. Rodriguésia 35/36: 99-128.

Miller RB. 1978. Potassium calcium sulphate crystals in the secondary xylem of Capparis. IAWA Bull. 1978: 50.

Mullendore DL, Windt CW, Van As H \& Knoblauch M. 2010. Sieve tube geometry in relation to phloem flow. The Plant Cell 22: 579-593.

Nakata PA. 2003. Advances in our understanding of calcium oxalate crystal formation and function in plants. Plant Science 164: 901-909. 
Netolitzky F. 1929. Die Kalksalze als Zelleninhaltskörper. In: Linsbauer K (ed.), Handbuch der Pflanzenanatomie. Allgemeiner Teil Cytologie. Band IIIa/Ia. pp. 20-78. Verlag von Gebrüder Borntraeger, Berlin.

O'Brien TP, Feder N \& McCully ME. 1964. Polychromatic staining of plant cell walls by toluidine blue. Protoplasma 59: 368-373.

O'Brien TP \& McCully ME. 1981. The study of plant structure principles and select methods. Termarcarphi Pty., Melbourne.

Pace MR, Alcantara S, Lohmann LG \& Angyalossy V. 2015. Secondary phloem diversity and evolution in Bignonieae (Bignoniaceae). Ann. Bot. 116: 333-358.

Parameswaran N \& Liese W. 1968. Beitrag zur Rindenanatomie der Gattung Entandrophragma. Flora Abt. B 158: 22-40.

Parameswaran N \& Liese W. 1970. Mikroskopie der Rinde tropischer Holzarten. In: Freund H (ed.). Umschau Verlag, Frankfurt.

Pearse AGE. 1968. Histochemistry: theoretical and applied, 3rd ed. Little, Brown \& Co, Boston.

Pearse AGE. 1985. Histochemistry: theoretical and applied, vol. 2. Churchill Livingstone, New York.

Pizzolato TD. 1977. Staining of Tilia mucilages with Mayer's tannic acid-ferric chloride. Bull. Torrey Bot. Club 104: 277-279.

Plowman AB. 1904. The celloidin method with hard tissues. Bot. Gaz. 37: 456-461.

Rajput KS. 2004. Occurrence of radial sieve elements in the secondary phloem rays of some tropical species. Israel J. Plant Sci. 52: 109-114.

Rajput KS \& Rao KS. 1998. Seasonal anatomy of secondary phloem of teak Tectona grandis L. (Verbenaceae) growing in dry and moist deciduous forests. Phyton 38: 251-258.

Richter HG. 1977. Differential staining of oil and mucilage in idioblasts of Lauraceae. IAWA Bull. 1977: 76.

Richter HG. 1981. Anatomie des sekundären Xylems und der Rinde der Lauraceae. Sonderbände des Naturwissenschaftlichen Vereins in Hamburg 5: 1-148.

Richter HG, Mazzoni-Viveiros SC, Alves ES, Luchi AE \& Costa CG. 1996. Padronização de critérios para a descrição anatômica da casca: lista de características e glossário de termos. IF-Sér. Reg. 16: 1-25.

Rosner S \& Kartusch B. 2003. Structural changes in primary lenticels of Norway spruce over the seasons. IAWA J. 24: 105-116.

Roth I. 1981. Structural patterns of tropical barks. In: Braun HJ, Carlquist S, Ozenda P \& Roth I. (eds.), Encyclopedia of Plant Anatomy: 1-609. Gebrüder Borntraeger, Berlin.

Ruffinatto F, Crivellaro A \& Wiedenhoeft AC. 2015. Review of macroscopic features for hardwood and softwood identification and a proposal for a new character list. IAWA J. 36: 208-241.

Rupp P. 1964. Polyglykol als Einbettungsmedium zum Schneiden botanischer Präparate. Mikrokosmos 53: 123-128.

Ruzin ES. 1999. Plant microtechnique and microscopy. Oxford University Press, New York.

Salatino A, Monteiro WR \& Bomtempi Jr N. 1988. Histochemical localization of phenolic deposits in shoot apices of common species of Asteraceae. Ann. Bot. 61: 557-559.

Sass JE. 1958. Botanical microtechnique. 3rd ed. The Iowa State College Press. Ames, Iowa.

Schenck H. 1893. Beiträge zur Biologie und Anatomie der Lianen, im Besonder on der in Brasilien einheimischen Arten. 2. Beiträge zur Anatomie der Lianen. In: Schimper AF (ed.), Botanische Mittheilungen aus den Tropen 5: 1-271. Gustav Fischer, Jena.

Schneider L \& Gärtner H. 2013. The advantage of using a starch based non-Newtonian fluid to prepare micro sections. Dendrochronologia 31: 175-178. 
Somavilla N, Cosenza GP, Fagg CW \& Brandão MGL. 2013. Morpho-anatomy and chemical profile of native species used as substitutes of quina (Cinchona spp.) in Brazilian traditional medicine. Part I: Polyouratea hexasperma. Rev. Brasil. Farmacogn. 23: 592-599.

Srivastava LM. 1963. Secondary phloem in the Pinaceae. University of California Publications in Botany 36: 1-142.

Stepanova AV, Oskolskii AA, Tilney PM \& Van Wyk BE. 2013. Wood anatomy of the tribe Podalyrieae (Fabaceae, Papilionoideae): Diversity and evolutionary trends. South Afr. J. Bot. 89: 244-256.

Strasburger E. 1891. Über den Bau und die Verrichtungen der Leitungsbahnen in den Pflanzen. Histologische Beiträge, Heft III. Gustav-Fischer, Jena, Germany.

Tamaio N. 2006. Anatomia do caule e da raiz em Menispermaceae. PhD diss., University of São Paulo, São Paulo.

Ter Welle BJH \& Mennega AMW. 1977. On the presence of large styloids in the secondary xylem of the genus Henriettea (Melastomataceae). IAWA Bull. 1977: 31-35.

Terrazas T \& Arias S. 2003. Comparative stem anatomy in the subfamily Cactoideae. Bot. Review 68: 444-473.

Thangstad OP, Iversen TH, Slupphaug G \& Bones A. 1990. Immunocytochemical localization of myrosinase in Brassica napus L. Planta 180: 245-248.

Tippett JT. 1986. Formation and fate of kino veins in Eucalyptus l'Hérit. IAWA Bull. n.s. 7: $137-143$.

Tomlinson PB. 2001. Reaction tissues in Gnetum gnemon: a preliminary report. IAWA J. 22: 401-413.

Tomlinson PB. 2003. Development of gelatinous (reaction) fibers in stems of Gnetum gnemon (Gnetales). Amer. J. Bot. 90: 965-972.

Tomlinson PB, Horn JW \& Fisher JB. 2011. The anatomy of palms: Arecaceae-Palmae. Oxford University Press.

Trockenbrodt M. 1990. Survey and discussion of the terminology used in bark anatomy. IAWA Bull. n.s. 11: 141-166.

Trockenbrodt M. 1995. Calcium oxalate crystals in the bark of Quercus robur, Ulmus glabra, Populus tremula and Betula pendula. Ann. Bot. 75: 281-284.

Tucker CM \& Evert RF. 1969. Seasonal development of the secondary phloem in Acer negundo. Amer. J. Bot. 56: 275-284.

Van Die J. 1955. A comparative study of the particle fractions from Apocynaceae latices. Ann. Bogor. 2: 1-124.

Van Veenendaal WLH \& Den Outer RW. 1993. Development of included phloem and organization of the phloem network in the stem of Strychnos millepunctata (Loganiaceae). IAWA J. n.s. 14: 253-265.

Van Wyk AE. 1991. Provisional bark character list. Revised October 31, 1991. Department of Plant Science, University of Pretoria, South Africa.

Waisel Y, Liphschitz N \& Arzee T. 1967. Phellogen activity in Robinia pseudoacacia L. New Phytol. 66: 331-335.

Wheeler EA. 2011. InsideWood - a web resource for hardwood anatomy. IAWA J. 32: 199_ 211.

Yeremin VM \& Kopanina AV. 2012. Atlas of the bark anatomy of trees, shrubs and lianas of Sakhalin and the Kuril Islands. Poligrafika, Brest (in Russian).

Yeung EC \& Chan CKW. 2015. Glycol methacrylate: the art of embedding and serial sectioning. Botany 93: 1-8.

Zhong Y, Baas P \& Wheeler EA. 1992. Wood anatomy of trees and shrubs from China. IV. Ulmaceae. IAWA Bull. n.s. 13: 419-453. 


\section{APPENDIX}

\section{MethodS}

Bark is composed typically of tissues that include hard, lignified cells, mixed with soft, unlignified cells. This combination makes bark a challenging material to obtain good histological sections, which are critical to produce accurate anatomical descriptions. Here we briefly present some of the methods already available in the literature or developed by some of our committee members to produce good sections. The reader interested in any specific technique is recommended to consult the original source, cited here, since we will provide only brief explanations of the most common methods. The reader is also strongly advised to look for safety and health information on all the reagents described in this short list of methods, since many are toxic and some carcinogenic.

\section{Material, fixation and conservation}

Since bark contains fragile cells that greatly change and often collapse when dried, the best materials for bark studies will be those collected and immediately immersed in a liquid fixative while still in the field and conserved afterwards also in liquid solutions. Large portions of bark or entire stems up to $3 \mathrm{~cm}$ long can be fixed in FAA (formaldehyde-acetic acid-50\% ethanol, in volume ratio of $5: 5: 90$, Johansen 1940). A little glycerin in the solution prevents the specimens from drying out over time (Keating 2014). Smaller bark or stem portions (up to $3 \times 3 \times 3 \mathrm{~mm}$ ), in which it is desirable to obtain cells with well-preserved cytoplasmatic contents, the better fixatives are the so-called noncoagulative ones. Examples are Craff III, IV, or V, paraformaldehyde or glutaraldehyde. The samples in general are kept in the fixatives for a week, after which they can be transferred to a conserving solution of $70 \%$ ethanol for as long as necessary. Leaving samples too long in the fixatives (months) make them friable.

\section{Rehydrating dried materials}

Sometimes only dried materials from wood and/or herbarium collections are available. Note that most of the soft tissues will have suffered in the process and changed considerably. Before any anatomical procedure is carried out, it is necessary to rehydrate the samples. This can be done by boiling the samples in water or a mixture of water and glycerin $(10: 1)$, until the samples are totally rehydrated. When originally floating samples sink in the solution, they are rehydrated.

\section{Maceration (Chamberlain 1935; Johansen 1940; Keating 2014)}

Maceration is a method that separates the tissues into single cells by disrupting the middle lamella. It is fundamental in the study of individual cells. Here we recommend the use of either Jeffrey's (Johansen 1940) or Franklin's maceration method (Franklin 1945). Both techniques consist in cutting the sample into small slices or slivers of the size of a matchstick. For Jeffrey's method place the sample in a solution of equal parts of $10 \%$ aqueous nitric acid and $10 \%$ aqueous chromic acid under a fume hood. For Franklin's method, place the sample in equal parts of glacial acetic acid and hydro- 
gen peroxide (20 volumes), equally within a fume hood. If the bark is resistant, the macerating solution, with the samples, can be put in a warm oven $\left(45-60^{\circ} \mathrm{C}\right)$ in jars with screw caps. Gases are produced in this process, use gloves and be under a fume hood. This procedure is not recommended for more fragile bark portions. Usually the cells start to separate in about 12-48 hours, but that may depend on the material. After this time, the material is thoroughly washed to remove all the acids. Then, with a thick glass rod or by beating gently with tweezers the material can be totally dissociated. The macerated material can then be stained with any suitable basic staining (check Johansen 1940 for staining pH). Among those, resorcin blue or toluidine blue are good options.

\section{Softening}

Hard bark samples contain a considerable amount of lignified cells, thus their sectioning is difficult. In this case, softening the material is critical. The length of time necessary to soften the samples will be determined by removing the samples periodically and testing with a sharp blade until they are found to be sufficiently soft to be sectioned (cross sections). The most common softening techniques used are described below.

\section{Boiling in water and glycerin}

Hard bark and wood samples can be softened by being boiled in water and glycerin $(10: 1)$ for a couple of hours, days to even up to a month. This method is suitable when the samples are easily destroyed in other softening media.

\section{Hydrofluoridric acid (Johansen 1940)}

Hydrofluoridric acid (also known as HF) has been traditionally used to soften hard tissues, including wood, and it usually yields good results. Material is submerged in a mixture of fuming HF (1 part) and $95 \%$ ethanol (3 parts) for 18 to 24 hours, depending on the size of the sample. Hydrofluoric acid is highly toxic, so a hood or fume-cupboard should be used. The solution, with the material, must be placed in high-quality plastic bottles with screw caps, which are tightly taped as a precaution. The treated material must be thoroughly washed in continuously flowing water for several days, before further anatomical techniques are carried out. Since hydrofluoric acid is very corrosive, rubber gloves must be used when handling it.

\section{Ethylenediamine (Kukachka 1977; Carlquist 1982)}

Samples are placed in $4 \%$ or $10 \%$ ethylenediamine for 24 to 36 hours (or up to a week). Results are obtained faster if the samples under treatment are placed in a warm oven (around $60^{\circ} \mathrm{C}$ ) in a closed bottle. Ethylenediamine usually yields good results, but may be unsuitable for certain taxa, in which the exposition to ethylenediamine makes the bark detach from the wood in a matter of hours (e.g., Malpighiaceae). Some adjustments to Carlquist's (1982) protocol for paraffin embedding are made in Hamann et al. (2011), especially for species with soft bark cells without sclerified cell walls, and for species with a heterogeneous combination of soft and hard bark tissues. 


\section{Sectioning}

Bark samples can be free-hand or microtome sectioned fresh. Usually fresh sections of non-treated material results in sections showing the fragile bark cells without any distortions, which is excellent and it is also much faster than many embedding procedures. However, embedding is a good option whenever thin and broad sections of the bark are desired. Note that a perfectly sharp knife, either disposable or permanent, is the most important aspect to obtain good sections. Here we describe some of the most common methods used in sectioning.

\section{Microtome types}

Rotary microtome - Usually samples embedded in either glycol methacrylate or paraffin are sectioned with rotary microtomes. Blocks of glycol methacrylate may be sectioned either with glass or steel knives, while paraffin blocks are usually sectioned with steel knives.

Sliding microtome - Large unembedded samples and samples embedded in polyethylene glycol are usually sectioned on a sliding microtome, with steel knives (either permanent or disposable ones).

Freezing microtome (Ruzin 1999) - Sectioning by freezing microtome (also called cryotome) does not require any previous embedding procedures and is suitable for fixed and fresh bark materials. Samples can be as large as $3 \times 3 \times 3 \mathrm{~mm}$. Sections are usually thicker than $10 \mu \mathrm{m}$, but good enough especially to study crystalliferous cells, secretory structures, and histochemical tests. The sample is frozen on the freezing stub and must be covered with ice. The frozen water is embedding in this case. To facilitate the sliding of sections on a blade, drip water onto the knife while sectioning. All other procedures follow normally.

\section{Sectioning facilitators}

\section{Cornstarch and glycerin solution}

The breakage or distortion of cellular structures can be limited by means of a solution made of cornstarch, water, and glycerin (10:8:7). Spreading the sticky liquid upon the bark before sectioning improves the overall quality of the sections, since this solution acts as a solid when pressured. In most cases the quality of the sections using this solution is comparable to that obtained from the more laborious and expensive embedding (Schneider \& Gärtner 2013; Gärtner \& Schweingruber 2013).

\section{Polystyrene foam resin (Barbosa et al. 2010)}

It is very common during sectioning that the bark detaches from the wood or that the hard components of the bark (e.g. sclereids and fibers) tear the tissue during sectioning. An effective method to overcome this involves the use of a polystyrene resin, which - in solution in butyl acetate - is placed upon the sample before sectioning. This resin dries and holds the entire section together, avoiding damage caused when manipulating the samples during staining and mounting. Since it is not soluble in water, it will only be removed from the sections when washed in either butyl acetate or acetone. All the procedures of bleaching and staining are carried normally in the presence of the polystyrene resin. 


\section{Embedding media}

Celloidin or Parlodion (Plowman 1904; Chamberlain 1935; Johansen 1940; Sass 1958)

A number of the samples shown in this Bark List were embedded in celloidin, which yields very good results in histology, especially for tough, brittle, or friable materials (Sass 1958). However, embedding in celloidin is no longer an option, since it has been removed from the market due to its inflammable, explosive nature. Other trademarks of nitrocellulose, such as parlodion, can still be bought in several countries and anatomists have been using it with success (Tomlinson et al. 2011).

Resin embedding (Bennet et al. 1976; Hamann et al. 2011; Yeung \& Chan 2015)

Several resins are available to impregnate biological tissues before sectioning. We discuss here glycol methacrylate and LR-White (hard grade) protocols. These embedding methods allow obtaining sections as thin as 1-3 $\mu \mathrm{m}$ without tissue distortion, but the samples have to be kept small $(2 \times 2 \times 2$ up to $5 \times 5 \times 5 \mathrm{~mm})$. Detailed descriptions of this method have been available for a long time (Feder \& O'Brien 1968) and improvements to this technique have been published (Bennet et al. 1976; Yeung \& Chan 2015). Usually, products on sale in the market have detailed procedures (e.g., Historesin, Leica), which often include dehydration (e.g. ethanol), followed by immersion in a solution of the dehydrating substance and glycol methacrylate (pre-embedding solution) and then pure embedding medium (methacrylate). Small and permeable tissues usually require less than a day for the entire process. However, our experience with impermeable bark parts showed that some samples need longer embedding times. Adequate results with glycol methacrylate have been obtained by leaving the samples in the pre-embedding solution for up to a month and the same amount of time in the embedding medium. Serial sections with the formation of ribbons can be obtained by adding polyethylene glycol 400 to the mixture (Yeung \& Chan 2015).

The LR-White protocol takes about one week, starting with $100 \%$ ethanol solution. The $100 \%$ ethanol is then gradually replaced by an increasing solution of LR-White using the following steps $3: 1,2: 1,1: 1,1: 2,1: 3$ ethanol:LR-White. As a last step, the samples are submerged into $100 \%$ LR-White in closed capsules and oven-dried at $60^{\circ} \mathrm{C}$ for 48 hours (often during the weekend). The embedding steps should occur under vacuum to improve the impregnation of the resin. LR-White embedding was found to be better than paraffin in a comparative study (Hamann et al. 2011).

\section{Paraffin (Johansen 1940; Carlquist 1982; Hamann et al. 2011)}

A traditional method, especially suitable for soft barks and when serial sections are required. Can be used for samples of $5 \times 5 \times 5$ up to $7 \times 7 \times 7 \mathrm{~mm}$, larger than when using glycol methacrylate. It includes dehydration to remove all water from the tissues, washing in tertiary butyl ethanol, and then gradually to solutions of paraffin and tertiary butyl ethanol until pure paraffin is reached. The material is mounted and after sectioning it is necessary to remove the paraffin. Most microtechnique books recommend xylol for this purpose, but butyl acetate, which is much less toxic, can also be used (at $60^{\circ} \mathrm{C}$ ) and is here recommended. 


\section{Polyethylene glycol 1500 (PEG) (Rupp 1964)}

Polyethylene glycol is very useful to embed large samples or even entire stems. It embeds quite easily, as it is soluble in water, and it softens the tissue along the embedding process. The original technique recommends to put the sample in a solution of PEG 1500 and water and just let the water evaporate over time, until pure PEG 1500 is reached (Rupp 1964). A modification of this technique was suggested by Barbosa et al. (2010) for bark and other heterogeneous tissues. It consists of a slower embedding process, involving the use of increasingly more concentrated solutions of PEG 1500, in $10-20 \%$ increments, until pure PEG is reached, allowing one day in each solution. This modification in the technique was shown to allow better penetration in more impermeable materials. In any case, the solution has to be kept in a hot oven above $50 \%$, since PEG 1500 is solid at room temperature.

\section{Staining}

Double staining or polychromatic staining is desirable in the study of bark, since the bark usually includes lignified and nonlignified cells. For double staining, the most common combinations are astra-blue and safranine (ab/s: acronyms in the figure captions; Bukatsch 1972) or fast-green and safranine (fg/s; Ruzin 1999). For the secondary phloem, it is strongly recommended to use resorcine blue (or lacmoid) and ferric chloride (rb/fc; Cheadle et al. 1953), since apart from double staining nonlignified (brown) and lignified tissues (blue), it also stains callose (bright blue), indicating the sieve plates and sieve areas. For polychromatic staining, toluidine blue is the most recommended (tb; O'Brien et al. 1964). Phloem sections stained in aqueous aniline blue and observed under polarized light is an easy and effective technique to demonstrate sieve tubes, since aniline blue stains callose (Foster 1949; Keating 2014). All of the staining methods above have been used to stain sections successfully in this list. In the figure captions we indicate the staining method using the acronyms assigned here.

\section{Histochemical tests}

Histochemistry is the association between histology and the identification of the chemical substances present in the tissues, as well as the exact localization of these substances. This detection is carried out with the aid of specific reagents. The use of controls and the observation of unstained sections should always accompany the tests. This is a simple measure to avoid false positive results, since numerous substances naturally possess colors or auto-fluorescence. Histochemical tests require the samples to be tested while fresh or fixed in specific fixatives for hydrophobic, lipophilic or phenolic compounds. Considering the most common fixatives, FAA is hydrophilic, neutral buffered formaldehyde is lipophilic and ferrous sulfate in formalin is adequate for phenolic compounds.

A few protocols are given below to detect certain substances; full protocols of some techniques can be downloaded in the Supplementary material to this Bark List*).

*) See the online edition of this IAWA Journal issue. 
Starch - Lugol (0.5 g iodine with $1 \%$ potassion iodide) applied for 5-10 minutes upon sections is typically used to detect starch. Starch gets dark blue in the presence of lugol. Sections can be fresh or fixed in FAA (Johansen 1940). Periodic-acid-Schiff's reaction (Jensen 1962; O’Brien \& McCully 1981) can also be used. Starch grains display an extinction cross under polarized light. Complete protocol available in Supplementary material*).

Inulin-type fructans/Inulin crystals - To detect inulin grains or crystals in a tissue treat freehand sections with a drop of $15 \%$ thymol (15 grams of thymol dissolved in $85 \mathrm{ml}$ of $95 \%$ alcohol) and subsequently add a few drops of concentrated sulfuric acid. The crystals turn carmine-red immediately as they dissolve (Johansen 1940; Blaydes 1943). Inulin hydrolizes rapidly to fructose. Therefore, the tissue has to be fixed in a nonhydrolizing killing fluid, such as FAA (Johansen 1940). Inulin-type crystals are formed when sections are immersed in alcohol and, similarly to starch, show as an extinction cross under polarized light (Joaquim et al. 2014).

Myrosin/protein cells - The best techniques to detect myrosin cells involve immunocytochemistry, immunolocalization, and tissue printing technology (Thangstad et al. 1990; Höglund et al. 1991; Andréasson et al. 2001; Ahuja et al. 2011). Cheaper, less specific techniques, involve the initial detection of total proteins with aniline blue black (Fisher 1968), with deep blue as positive result, or xylidine ponceau (O'Brien \& McCully 1981), with red as positive result. Specific tests to detect myrosin cells, carried out with ammoniacal silver nitrate (Costa 1982), with black as positive result. Complete protocols are available in Supplementary material*).

Phenolic substances (including tannins) - Phenolic substances can be detected with ferrous sulfate in formalin (Johansen 1940; Salatino et al. 1988) or ferric chloride (Grahan 1984). In ferrous sulfate/formalin the phenolic substance becomes dark-brown to black, while in ferric chloride it turns green for polyphenols and blue-black for tannins. To check whether the phenolic substance is tannin, vanillin-hydrochloric acid is used (Mace \& Howell 1974). The presence of tannins results in a red color. Complete protocols are available in Supplementary material*).

Oils and Resins - Oils and resins are soluble in high-grade alcohols, xylol and toluene. Thus, to detect the presence of oils and resins the samples need to be kept in aqueous solutions. Double staining with chrysoidin and acridin red is used to detect oils and resins, which turn reddish, varying from pink to purple (Richter 1977; Bakker \& Gerritsen 1992). Terpenoids, which are essential oils, can be detected with Nadi reagent. Positive results are blue for essential oils, violet for oleoresin and red for resiniferous acids. Complete protocols are available in Supplementary material*).

*) See the online edition of this IAWA Journal issue. 
Mucilages - Mucilages are water-soluble and therefore the tissues to be tested need to be kept in high-grade ethanol. Samples may be fresh or fixed in FAA; embedded in paraplast, paraffin or glycol methacrylate. Mucilages stain heavily with alcian blue or astra-blue. General mucilages can be detected with the Mayer reaction (Pizzolato 1977), with mucilages turning black. Acid mucilages turn brigh red with ruthenium red (Gregory \& Baas 1989). Complete protocols are available in Supplementary material*).

Laticifers/latex - Whenever ruptured, laticifers rapidly start to flow. Therefore, samples need to be cut with a hot blade to preserve the latex inside the system (Milanez 1960/1961). Latex can be composed of various substances, which demand different histochemical tests. Examples of substances that may be present in latex are polyisoprene hydrocarbons (rubber or gutta percha), triterpenols, sterols, fatty acids, aromatic acids, carotenes, phospholipids, proteins, starch, and inorganic constituents (Van Die 1955; Castro \& Demarco 2008). Rubber can be detected with oil red/oil blue reactions (Pearse 1968; Jayabalan \& Shah 1986). Rubber particles become red under light microscopy and fluorescent red under UV light. Lipids can be detected with Sudan Black B (Pearse 1985), with blue, black or brownish black as positive reaction. Nile blue (High 1984) produces a pink color for acid and neutral lipids, and a blue one for acid lipids. Samples must be fresh or fixed in neutral buffered formalin (Lillie 1948), and embedded in paraplast or glycol methacrylate. Alkaloids may be detected with Wagner reagent (Furr \& Mahlberg 1981), with reddish-brown as positive reaction. Total polysaccharides may be detected with Periodic-acid-Schiff's reaction (Jensen 1962), with magenta, purple red or pink as positive reactions. Complete protocols are available in the Supplementary material*).

Suberin and other lipids (Johansen 1940; Ruzin 1999) - Sudan dyes are used to detect suberin and other lipids. Either Sudan III, IV, or Sudan Black B is dissolved in $70 \%$ ethanol and applied to the sections. Let the samples incubate for 5-10 $\mathrm{min}$ in the dye solution, rinse them in $50 \%$ ethanol and then mount in glycerin. Suberin and other lipids turn orange or red in Sudan III and IV.

References to this Appendix are included in the general references on pages $602-$ 608.

*) See the online edition of this IAWA Journal issue. 


\author{
Supplementarymaterial to the \\ IAWA List of Microscopic Bark Features \\ IAWA Journal 37 (4): 517-615
}

\title{
RECIPES AND PROTOCOLS FOR HISTOCHEMICAL TESTS
}

\author{
Solange C. Mazzoni-Viveiros ${ }^{1,3}$ and Marília de Moraes Castro ${ }^{2}$ \\ ${ }^{1}$ Secretaria de Estado do Meio Ambiente, Instituto de Botânica de São Paulo, \\ Núcleo de Pesquisa em Anatomia, São Paulo, SP, Brazil \\ ${ }^{2}$ Universidade Estadual de Campinas, Instituto de Biologia, Departamento de Biologia Vegetal, \\ Campinas, SP, Brazil \\ ${ }^{3}$ Corresponding author: scmazzoni.viveiros@gmail.com
}

\section{MYROSIN CELLS / PROTEIN CELLS}

Myrosin cells contain the enzyme myrosinase in their central vacuoles. This enzyme mixes with its substrate compounds, thioglucosides, present in the surrounding cells whenever the cells are damaged, for instance by a chewing animal. This results in a toxic mustard oil (isothiocyanate), a plant defense compound (Björkman 1976; Fahn 1979; Mauseth 1988).

The best techniques to detect myrosin cells are immunocytochemical or immunolocalization (Thangstad et al. 1990; Höglund et al. 1991; Andréasson et al. 2001; Ahuja et al. 2011), and tissue printing technology (Hara et al. 2000). However, these techniques require an elaborate infrastructure in the laboratory.

The methodologies commonly used to detect myrosin cells are diverse, and for the most part nonspecific. The most used is the histochemical reaction to detect total proteins (Fisher 1968; Jørgensen et al. 1977; O’Brien \& McCully 1981; Jørgensen 1995; Andréasson et al. 2001; Thadeo et al. 2008; Bosabalidis 2014), while another is a specific reaction to detect isothiocyanate presence (Costa 1982; Zanetti et al. 2004).

As myrosin cells have been found in just a few families, mostly Brassicaceae and Capparaceae (order Brassicales), it is possible to use one technique to detect total proteins to make the first survey in the bark sample. If the result of the protein test is positive, other specific techniques can be used to confirm the presence of myrosinase.

\section{Total protein tests}

\section{ABB - Aniline blue black - CI 20470 (Fisher 1968)}

The sections, fresh or fixed in FAA (Johansen 1940), must be stained with $1 \%$ aniline blue black in $7 \%$ acetic acid for 10 minutes, at room temperature or gently heated; dipped briefly in 7\% acetic acid; washed in distilled water; mounted in distilled water. The positive result is a deep blue color. 
2. XP - Xylidine Ponceau - CI 16150 (O’Brien \& McCully 1981)

The sections, fresh or fixed in FAA (Johansen 1940), must be stained with $0.1 \%$ Xylidine Ponceau in $3 \%$ acetic acid ( $\mathrm{pH} 2.5$ ) for 15 minutes; rinsed in $3 \%$ acetic acid; washed in distilled water; mounted in distilled water or dried naturally and mounted in synthetic resin. The positive result is a red color.

Negative control to $A B B$ and $X P$ : Use fresh sections or sections in which the paraffin was removed (or any other synthetic resin); hydrate the samples coming from high grade ethanol toward distilled water; incubate in a fresh solution of $5 \%$ trichloroacetic acid at $90^{\circ} \mathrm{C}$ for 15 minutes; pass to $70 \%$ ethanol at $50{ }^{\circ} \mathrm{C}$ (water bath or oven) for 10 minutes; make two changes of $70 \%$ ethanol at room temperature for 10 minutes each; rinse in distilled water; divide the slides into two groups, incubate one group in phosphate buffer $0.05 \mathrm{M}$ ( $\mathrm{pH} 8.9$ ), and the other in trypsin solution (10 mg trypsin in $100 \mathrm{ml}$ phosphate buffer $0.05 \mathrm{M}$ ) at $37 \%$ (water bath or oven) for 15 to 60 minutes; rinse both groups in distilled water, using separated incubation bottles; proceed with the protein tests above. If the protein is present, the result for the group incubated with only phosphate buffer has to be positive, while the result for the group incubated with trypsin solution has to be negative (modified from Pearse 1960).

\section{Isothiocyanate test}

Solution of Ammoniacal silver nitrate (Costa 1982)

Preparation of solution: Dissolve $0.5 \mathrm{~g}$ silver nitrate in $5 \mathrm{ml}$ distilled water; add 5 (five) drops of $\mathrm{NaOH} 40 \%$ and add, drop by drop, ammonia until the precipitate dissolves. Complete with distilled water to obtain $20 \mathrm{ml}$ of solution.

The fresh sections must be mounted in the solution of the ammoniacal silver nitrate and lightly warmed. Instantly the isothiocyanate reduces ammoniacal silver nitrate to metallic silver, a black precipitate of silver. The isothiocyanate in the myrosin cells exhibits a black color.

\section{TANNINS AND PHENOLIC COMPOUNDS}

Although phenolic compounds are commonly present in the early stages of development of some tissues, only when they are present in mature tissue in high concentration are they considered a kind of plant secretion, and may be present in single cells (idioblasts) or tubes (tubules).

There are several histochemical treatments useful to detect phenolic compounds, but vanillin-hydrochloric acid is the only histochemical test for tannins (Gardner 1995; Castro \& Demarco 2008). In the absence of histochemical testing, it is recommended to refer to cells with colored contents as "secretory cells", with the color of the unstained contents as qualifier.

\section{Tannin test}

\section{Vanillin-hydrochloric acid according to Gardner (1995)}

Fresh sections must be submitted to a drop of saturated alcoholic vanillin; followed by several drops of concentrated $\mathrm{HCl}$. The presence of condensed tannin in the tissue is indicated by development of a bright-red color. 
2. Vanillin-hydrochloric acid according to Mace \& Howell (1974)

Fresh sections must be submitted in a $5 \%$ vanillin in $9 \%$ hydrocloridric acid solution for 10 minutes and then mounted in $9 \%$ hydrocloridric acid. The presence of condensed tannin in the tissue is indicated by development of a red color.

\section{Phenolic compounds}

1. Ferrous sulfate in formalin (Johansen 1940; Salatino et al. 1988)

Add $2 \mathrm{~g}$ ferrous sulfate $\left(\mathrm{FeSO}_{4} \cdot 7 \mathrm{H}_{2} \mathrm{O}\right), 10 \mathrm{ml}$ formaldehyde solution (37-40\%), $90 \mathrm{ml}$ distilled water. Expose the vial with fixed material to moderate vacuum to pull the air out of the tissue. The minimum time of fixation is 48 hours. Wash the material in distilled water for 90 minutes (5-6 changes) and store it in $70 \%$ ethanol before embedding. The presence of phenolic compound in the tissue is indicated by the darkbrown to black color.

\section{Ferric chloride (Gahan 1984)}

Preparation of solution: Add $2 \mathrm{~g}$ ferric chloride in $100 \mathrm{ml} 95 \%$ ethanol.

Fresh sections must be submitted in the ferric chloride solution for 5 minutes; rinsed in $95 \%$ ethanol; hydrated; examined directly or mounted in Euparal or, following full dehydration, an alternative mounting medium. The positive results are green for polyphenols, and blue-black for tannins.

Negative control for lipophilic phenolic compounds: The sample must be kept in chloroform/methanol/distilled water/hydrochloric acid solution $(66: 33: 4: 1)$ for 24 hours at room temperature and subsequently be submitted to the same procedures as above (High 1984).

\section{OIL AND RESIN}

Essential oils or resins easily dissolve in organic solvents that are commonly used in plant microtechnique such as high-grade ethanol, xylene, and toluene. For sectioning and staining barks to demonstrate essential oil or resin contents, samples should be confined to aqueous media and solutions.

Richter (1977) and Bakker \& Gerritsen (1992) suggest double staining with aqueous solution of chrysoidin and acridin red to preliminary test for oil cells.

Chrysoidin - CI 11270 / Acridin red - CI 45000 (Richter 1977; Bakker \& Gerritsen 1992)

Cut sections of unembedded material, lubricating the knife with water; stain with an aqueous solution of $0.5 \% / 0.5 \%$ chrysoidin/acridin red; mount in glycerin. Oils obtain a reddish hue, varying from pink to bright crimson to purple.

\section{Terpenoid test}

Oils and resins belong to the terpenoid group of compounds. The mono- and sesquiterpenoids are volatiles and give flavor and fragrance to the tissue, they are also known as essential oils. The di- and triterpenoids are nonvolatile, they are obtained from plant gums and resins. 
The histochemical test for these nonvolatile types of terpenoids is the Nadi reagent using fresh material (David \& Carde 1964).

Nadi reagent (David \& Carde 1964)

Preparation of solution (store in the dark): Add $0.5 \mathrm{ml}$ alpha-naphthol $0.1 \%$ in $40 \%$ ethanol, $0.5 \mathrm{ml}$ dimethyl-para-phenylene diamina chlorohydrate $1 \%, 49 \mathrm{ml}$ sodium phosphate buffer $0.05 \mathrm{M}$ at $\mathrm{pH} 7.2$.

Fresh sections must be submerged in Nadi reagent (in the dark) for 1 hour at room temperature; washed for 2 minutes in sodium phosphate buffer $0.1 \mathrm{M}$ at $\mathrm{pH} 7.2$; mounted in the same sodium phosphate buffer. Positive results are a blue color for essential oils, a violet color for oleoresin, and a red color for resiniferous acids.

Negative control: The sample must be kept in chloroform/methanol/distilled water/ hydrochloric acid solution $(66: 33: 4: 1)$ for 3 hours at room temperature and subsequently be submitted to the same procedures as above (High 1984).

\section{MUCILAGE}

Plant mucilages are polysaccharides that increase in volume in water, forming gels or slimy substances. The viscosity proprieties change according to the $\mathrm{pH}$ and hydration levels. Because mucilage readily dissolves in aqueous solutions, the protocol for demonstrating the presence of mucilage cells or mucilage cavities should be done in high-grade ethanol.

In all these tests the material may be either fresh or fixed in FAA in $70 \%$ ethanol (Johansen 1940). The embedding media may be paraplast, paraffin or plastic resin.

Astra-blue - CI 34195 (Merckcatalog 1278) / Alcian blue - CI 74240 (Richter 1977; Bakker \& Gerritsen 1992)

Cut sections of embedded material, lubricating the knife with $96 \%$ ethanol; stain with a $1 \%$ Astra-blue or Alcian blue solution in 60-70\% ethanol; following full dehydration mount in Depex or an alternative mounting medium. The positive result is an intense blue color.

\section{Types of mucilage}

There are two simple tests to reliably detect general mucilages (Pizzolato 1977) or acid mucilages (Gregory \& Baas 1989).

\section{Mayer reaction (Pizzolato 1977)}

The sections must be submitted, for 10 minutes, to a solution of $5 \%$ tannic acid; washed in distilled water for about 15 seconds, followed by $2 \%$ solution of ferric chloride for 1 minute; washed in distilled water; dehydrated in an alcoholic series and mounted in synthetic resin. The presence of mucilages is indicated by a black color.

Negative control: Submit the sections only to tannic acid.

\section{Ruthenium red - CI 77800 (Gregory \& Baas 1989)}

The sections must be submitted for 10 minutes or more to a solution of $8 \mathrm{mg}$ of Ruthenium red in $10 \mathrm{ml}$ of $10 \%$ aqueous lead acetate; washed in distilled water; mounted in distilled water. The presence of mucilages is indicated by a bright-red color. 


\section{LATEX}

Laticifers are either specialized cells or a row of such cells containing latex. Laticifers are relatively easy to be recognized, sometimes because of their content, presence of ramifications and/or distinctive wall. Laticifer distribution varies within the plant body, and may be found in the entire plant body or be restricted to certain tissue or organs (Metcalfe 1983; Mahlberg 1993).

According to Milanez (1946) and Backhaus \& Walsh (1983), laticifer content is the cytoplasm of the cell(s), while Demarco et al.(2006) suggested the term protoplast, because laticifers may retain their nuclei. The content composition varies in the different plant families or species. Latex can be white and milky, but may be also yellow, orange, red, greenish, or transparent (Fahn 1979).

\section{Collection}

If the laticifer system is ruptured the latex flows quickly, so, to collect good material to study, the samples need to be cut with a hot blade to preserve the latex inside the system (Milanez 1960/1961; Demarco et al. 2006; Martins et al. 2013).

\section{Composition of the latex}

Latex composition is specific and demands different histochemical tests suggested in the literature. Within latex it is possible to find polyisoprene hydrocarbons (rubber or gutta percha), triterpenols and sterols, fatty acids and aromatic acids, carotenes, phospholipids, proteins and inorganic constituents (Van Die 1955). Furr \& Mahlberg (1981) suggested using fresh material with different kinds of reagents to analyze the latex composition. Salatino et al. (1988) elucidated the use of formalin-ferrous sulfate fixative to localize phenolic deposits in plants. Demarco et al. (2006) suggested two kinds of fixatives, FAA for hydrophilic compounds (Johansen 1940) and neutral buffered formalin for lipophilic compounds (Lillie 1948) and specific histochemical tests to analyze the various possible compounds of latex. Martins et al. (2013) suggested also using formalin-ferrous sulfate fixative to detect phenolic compounds in latex.

\section{Rubber test}

Although the presence of rubber is not required to define the cell as a laticifer, sometimes the latex contains rubber and to detect it, it is recommended to use the following reaction.

Oil Red O - CI 26125 / Oil Blue N reactions - CI 61555 (Pearse 1968, modified by Jayabalan \& Shah 1986)

Fresh sections must be submerged in a saturated solution of the Oil Red O or Oil Blue $\mathrm{N}$ in $90 \%$ formic acid for 3 to 5 minutes; washed in distilled water; mounted in glycerin for normal light microscopy or $50 \%$ glycerin for fluorescence microscopy. The rubber particles obtain a red color under light microscopy and fluoresce pallid red under UV light.

Negative control: The sections must be kept in a mixture of chloroform/methanol/ distilled water/hydrochloric acid $(66: 33: 4: 1)$ for 1 hour at room temperature and afterward be submitted to the same procedures as above (High 1984). 


\section{Lipid tests}

The different types of lipids are detected by specific tests, like Sudan black B for general lipids (Pearse 1985), Nile blue for acid and neutral lipids (High 1984), and the Holczinger reaction for free fatty acids (High 1984). Ganter \& Jollés (1969) suggested the osmium tetroxide test for unsaturated lipids, but this should be avoided because of its toxicity.

In all these tests the material may be fresh or fixed in neutral buffered formalin (Lillie 1948), and embedded in paraplast or plastic resin.

\section{Sudan black B - CI 26150 (Pearse 1985)}

The sections must be submitted to a saturated solution of Sudan black B in $70 \%$ ethanol, for 15 (fresh section) or 30 (embedded sections) minutes, at room temperature or at $60{ }^{\circ} \mathrm{C}$; rinsed quickly in $70 \%$ ethanol; washed in distilled water; mounted in distilled water. The positive results are a blue, black or brownish-black color for total lipids.

Negative control: The sample must be kept in a mixture of chloroform/methanol/ distilled water/hydrochloric acid $(66: 33: 4: 1)$ for 3 hours at room temperature and subsequently be submitted to the same procedures as above (High 1984).

\section{Nile blue - CI 51180 (High 1984)}

Preparation of Nile blue sulfate solution: add $200 \mathrm{ml}$ of $1 \%$ Nile blue sulfate with $10 \mathrm{ml}$ of $1 \%$ sulfuric acid. Leave to boil for 4 hours and filtrate $(\mathrm{pH} 2)$.

The sections must be submitted to Nile blue sulfate for 30 minutes at $37^{\circ} \mathrm{C}$; differentiated in $1 \%$ acetic acid for 2 minutes; washed well in distilled water; mounted in glycerol-gelatin. The positive result is a pink color for neutral lipids and a blue color for acid lipids.

Negative control: The sample must be kept in a mixture of chloroform/methanol/ distilled water/hydrochloric acid $(66: 33: 4: 1)$ for 3 hours at room temperature and subsequently be submitted to the same procedures as above (High 1984).

\section{Holczinger reaction (High 1984)}

The sections must be submitted to $0.005 \%$ cupric acetate for 3 hours; washed twice for 10 seconds with $0.1 \%$ EDTA (ethylenediamine tetra acetic acid) adjusted to $\mathrm{pH} 7.0$ with $\mathrm{NaOH}$; washed thoroughly in distilled water; treat these sections for 10 minutes with $0.1 \%$ rubeanic acid in $70 \%$ ethanol; rinse in $70 \%$ ethanol; wash quickly in water; mount in glycerin-jelly. Free fatty acids stain a dark green color.

Negative control: The sample must be kept in chloroform/methanol/distilled water/ hydrochloric acid solution $(66: 33: 4: 1)$ for 3 hours at room temperature and subsequently be submitted to the same procedures as above (High 1984).

\section{Tests of other latex components}

The tests used to detect phenolic compounds and terpenoids in latex are the same as those cited above for tannins and phenolic compounds, and oil and resin, while the tests to detect proteins and enzymes are the same as cited for myrosin/protein cells. 
Alkaloids may be detected using Wagner reagent (Furr \& Mahlberg 1981), the total polysaccharides using Periodic-acid-Schiff's reaction (Jensen 1962) and the starch by using Lugol reagent (Johansen 1940).

\section{Wagner reagent (Furr \& Mahlberg 1981)}

Preparation of reagent: Add $2 \mathrm{~g}$ of potassium iodide, $1.27 \mathrm{~g}$ iodine, $100 \mathrm{ml}$ distilled water.

The sections must be submitted to Wagner reagent for 5-10 minutes; washed and mounted in distilled water. The positive result is a reddish-brown precipitate for alkaloids.

Negative control: The sections must be kept in 5\% tartaric acid in $98 \%$ ethanol for 48-72 hours, washed in distilled water and subsequently be submitted to the same procedures as above.

2. Periodic-acid-Schiff's reaction (Jensen 1962; O’Brien \& McCully 1981)

Preparation of Schiff's reagent: Add $7 \mathrm{~g}$ basic fuchsin (CI 42510) in $60 \mathrm{ml}$ hydrochloride acid $1 \mathrm{~N}$, mix in $2 \mathrm{~g}$ sodium metabisulfite in $300 \mathrm{ml}$ distilled water, let it rest for 24 hours in a closed bottle stored in the dark. Add $1.2 \mathrm{~g}$ activated charcoal, shake for 2 minutes, filter and store in a dark bottle for 24 hours at $4{ }^{\circ} \mathrm{C}$ (the filtrate should be colorless).

Sections, fresh or fixed in FAA (Johansen 1940), must be submitted to $1 \%$ aqueous sodium borohydride recently prepared for 30 minutes at room temperature (blocks aldehydes in sections of fixed material); rinsed in distilled water for 10 minutes; $1 \%$ periodic acid solution for 7 minutes (step omitted in controls); washed in running tap water for 10 minutes; Schiff's reagent for 15 minutes; rinsed in distilled water (three baths of 2 minutes each); washed in $2 \%$ sodium metabisulfite solution for 2 minutes; washed in running tap water for 10 minutes; mounted in Kaiser's gelatin or in distilled water. The positive results are magenta, purple red or pink colors for polysaccharides.

Negative control: The sections must be processed equally to the description above but leaving out the periodic acid treatment.

\section{REFERENCES}

Ahuja I, Borgen BH, Hansen M, Honne BI, Müller C, Rohloff J, Rossiter JT \& Bones AM. 2011. Oilseed rape seeds with ablated defence cells of the glucosinolate-myrosinase system. Production and characteristics of double haploid MINELESS plants of Brassica napus L. Journal of Experimental Botany 62: 4975-4993.

Andréasson E, Jørgensen LB, Höglund AS, Rask L \& Meijer J. 2001 . Different myrosinase and idioblast distribution in Arabidopsis and Brassica napus. Plant Physiology 127: 1750-1763.

Backhaus RA \& Walsh S. 1983. The ontogeny of rubber formation in guayule, Parthenium argentatum Gray. Botanical Gazette 144: 391-400.

Bakker ME \& Gerritsen AF. 1992. Oil and mucilage cells in Annona (Annonaceae) and their systematic significance. Blumea 36: 411-438.

Björkman R. 1976. Properties and function of plant myrosinases. In: Vaughan JG, MacLeod AJ \& Jones BMG (eds.), The biology and chemistry of Cruciferae: 191-206. Academic Press, London. 
Bosabalidis AM. 2014. Isioblastic mucilage cells in Teucrium polium leaf, anatomy and histochemistry. Modern Phytomorphology 5: 49-52.

Castro MM \& Demarco D. 2008. Phenolic compounds produced by secretory structures in plants: a brief review. Natural Product Communications 3: 1273-1284.

Costa AF. 1982. Farmacognosia. Farmacognosia Experimental. v.3, 2nd ed. Fundação Calouste Gulbenkian, Lisboa.

David R \& Carde JP 1964. Coloration différentielle des inclusions lipidiques et terpéniques des pseudophylles du pin maritime au moyen du réactif nadi. Comptes Rendus de l'Académie des Sciences Paris, Sér D 258: 1338-1340.

Demarco D, Kinoshita LS \& Castro MM. 2006. Articulated anatomosing laticifers - new records for Apocynaceae. Revista Brasileira de Botânica 29: 133-144.

Fahn A. 1979. Secretory tissues in plants. Academic Press, London.

Fisher DB. 1968. Protein staining of ribboned epon sections for light microscopy. Histochemistry 16: 92-96.

Furr M \& Mahlberg PG. 1981. Histochemical analyses of laticifers and glandular trichomes in Cannabis sativa. Journal of Natural Products 44: 153-159.

Gahan PB. 1984. Plant histochemistry and cytochemistry. Academic Press, London.

Ganter P \& Jollés G. 1969. Histochimie normale et pathologique. Gauthier-Villars, Paris.

Gardner RO. 1995. Vanillin-hydrochloric acid as a histochemical test for tannin. Stain Technology 50: $315-317$.

Gregory M \& Baas P. 1989. A survey of mucilage cells in vegetative organs of the dicotyledons. Israel Journal of Botany 38: 125-174.

Hara M, Fujii Y, Sasada Y \& Kuboi T. 2000. cDNA cloning of radish (Raphanus sativus) myrosinase and tissue-specific expression in root. Plant Cell Physiology 41: 1102-1109.

High OB. 1984. Lipid histochemistry. Royal Microscopical Society. Microscopy Handbooks 06. Oxford University Press, Oxford.

Höglund AS, Lenman M, Falk A \& Rask L. 1991. Distribution of myrosinase in rapeseed tissues. Plant Physiology 95: 213-221.

Jayabalan M \& Shah JJ. 1986. Histochemical techniques to localize rubber in guayule (Parthenium argentatum Gray). Stain Technology 61: 303-308.

Jensen WA. 1962. Botanical histochemistry: principles and practice. W.H. Freeman and Co., San Francisco.

Johansen DA. 1940. Plant microtechnique. McGraw-Hill Book Company, New York.

Jørgensen LB. 1995. Stomatal myrosin cells in Caricaceae: taxonomic implications for a glucosinolate-containing family. Nordic Journal of Botany 15: 523-540.

Jørgensen LB, Behnke HD \& Mabry TJ. 1977. Protein accumulating cells and dilated cisternae of the endoplasmic reticulum in three glucosinolate-containing genera: Armoracia, Capparis, Drypetes. Planta 137: 215-224.

Lillie RD. 1948. Histopathologic technic. Blakiston, Philadelphia.

Mauseth JD. 1988. Plant anatomy. The Benjamin/Cummings Publishing Co., California.

Mace ME \& Howell CR. 1974. Histochemistry and identification of condensed tannin precursor in roots of cotton seedlings. Canadian Journal of Botany 52: 2423-2426.

Mahlberg PG. 1993. Laticifers: an historical perspective. The Botanical Review 59: 1-23.

Martins FM, Mascarenhas AAS, Macedo TP \& Cunha Neto IL. 2013. Secretory structures in vegetative and floral organs of Secondatia densiflora A.DC. (Apocynaceae - Apocynoideae - Odontadenieae). Revista Brasileira de Plantas Medicinais 15: 13-24.

Metcalfe CR. 1983. Laticifers and latex. In: Metcalfe CR \& Chalk L (eds.), Anatomy of the dicotyledons. Wood, structure and conclusion of the general introduction. Vol. 2, 2nd ed.: 70-81. Clarendon Press, Oxford. 
Milanez FR. 1946. Nota prévia sobre laticíferos de Hevea brasiliensis. Arquivos do Serviço Florestal 2: 39-65.

Milanez FR. 1960/1961. Contribuição ao conhecimento anatômico de Cryptostegia grandiflora. II. Sobre os laticíferos da estrutura primária (Asclepiadaceae). Rodriguésia 35/36: 99-128. O'Brien TP \& McCully ME. 1981. The study of plant structure. Principles and selected methods. Termarcarpri Pty Ltd, Melbourne.

Pearse AGE. 1960. Histochemistry: theoretical and applied. 2nd ed. J \& A Churchill, London.

Pearse AGE. 1968. Histochemistry: theoretical and applied. 3rd ed. Little, Brown \& Co, Boston.

Pearse AGE. 1985. Histochemistry theoretical and applied. Vol. II, 4th ed. Churchill Livingstone, London.

Pizzolato TD. 1977. Staining of Tilia mucilages with Mayer's tannic acid-ferric chloride. Bulletin of the Torrey Botanical Club 104: 277-279.

Richter HG. 1977. Differential staining of oil and mucilage idioblasts of Lauraceae. IAWA Bulletin 4: 76.

Salatino A, Monteiro WR \& Bomtempi Jr N. 1988. Histochemical localization of phenolic deposits in shoot apices of common species of Asteraceae. Annals of Botany 61: 557-559.

Thadeo M, Cassino MF, Vitarelli NC, Azevedo AA, Araújo JM, Valente VMM \& Meira RMSA. 2008. Anatomical and histochemical characterization of extrafloral nectaries of Prockia crucis (Salicaceae). American Journal of Botany 95: 1515-1522.

Thangstad OP, Iversen TH, Slupphaug G \& Bones A. 1990. Immunocytochemical localization of myrosinase in Brassica napus L. Planta 180: 245-248.

Van Die J. 1955. A comparative study of the particle fractions from Apocynaceae latices. Annales Bogorienses 2: 1-124.

Zanetti GD, Manfron MP \& Hoelzel SCS. 2004. Análise morfo-anatômica de Tropaeolum majus L. (Tropaeolaceae). Iheringia 59: 173-178. 